W I L L I A M G. G A L E

Brookings Institution

PETER R. ORSZA G

Brookings Institution

\title{
Budget Deficits, National Saving, and Interest Rates
}

ECONOMIC ANALYSIS OF the aggregate effects of fiscal policy dates back at least to the work of David Ricardo. Modern academic interest was reinvigorated by the work of Robert Barro and others and by the emergence of large U.S. federal budget deficits in the 1980s and early 1990s. ${ }^{1}$ The result was a substantial amount of research, which is summarized in several excellent surveys. ${ }^{2}$ The rapid but short-lived transition to budget surpluses in the late 1990s, followed by the sharp reversal in budget outcomes since 2000, has raised interest in this topic again.

Economists tend to view the aggregate effects of fiscal policy from one of three perspectives. To sharpen the distinctions among them, it is helpful to consider a deficit induced by a lump-sum tax cut today followed by a lump-sum tax increase in the future, holding the path of government purchases and marginal tax rates constant. Under the Ricardian equivalence hypothesis proposed by Barro, such a deficit will be fully offset by an increase in private saving, as taxpayers recognize that the tax is merely postponed, not canceled. The offsetting increase in private saving means that the deficit will have no effect on national saving, interest rates,

We thank Christopher House for exceptionally helpful comments and discussions; Emil Apostolov, Matt Hall, Brennan Kelly, and Melody Keung for outstanding research assistance; Alan Auerbach, Robert Cumby, William Dickens, Douglas Elmendorf, Eric Engen, Laurence Kotlikoff, Thomas Laubach, William Nordhaus, David Pattison, Maria Perozek, Frank Russek, John Seater, Matthew Shapiro, and David Wilcox for comments; and Eric Engen, Jane Gravelle, and Thomas Laubach for sharing data.

1. Barro (1974).

2. See Barro (1989), Barth and others (1991), Bernheim (1987, 1989), Elmendorf and Mankiw (1999), and Seater (1993). 
exchange rates, future domestic production, or future national income. A second model, the small open economy view, suggests that budget deficits do reduce national saving but, at the same time, induce increased capital inflows from abroad that finance the entire reduction. As a result, domestic production does not decline and interest rates do not rise, but future national income falls because of the added burden of servicing the increased foreign debt. A third model, which we call the conventional view, likewise holds that deficits reduce national saving but that this reduction is at least partly reflected in lower domestic investment. In this model, budget deficits partly crowd out private investment and partly increase borrowing from abroad; the combined effect reduces future national income and future domestic production. The reduction in domestic investment in this model is brought about by an increase in interest rates, thus establishing a connection between deficits and interest rates.

We emphasize throughout this paper that the relationship between deficits and national saving is central to the analysis of the economic effects of fiscal policy. National saving, which is the sum of private and government saving, finances national investment, which is the sum of domestic investment and net foreign investment. ${ }^{3}$ The accumulation of assets, whether located in the United States or abroad, associated with national saving means that the capital stock owned by Americans rises. The returns to those additional assets raise the income of Americans in the future.

An increase in the budget deficit reduces national saving unless it is fully offset by an increase in private saving. If national saving falls, national investment and future national income must fall as well, all else equal. Therefore, to the extent that budget deficits reduce national saving, they reduce future national income. This reduction occurs even if there is no increase in domestic interest rates. In that case the reduction in national saving associated with budget deficits manifests itself solely in increased borrowing from abroad (the outcome under the small open economy view). This is the sense in which the effect of deficits on interest rates and exchange rates (which distinguishes the small open economy view from the conventional view) is subsidiary to the question of the

3. Domestic investment represents the accumulation of assets in a country by both its own residents and foreigners. Net foreign investment is the accumulation of assets abroad by residents less the accumulation of assets in the home country by foreigners. The sum of the two is just the accumulation of assets, by residents, in the home country and abroad. This sum must equal national saving. 
effect on national saving (to which the Ricardian view gives a different answer than the other two).

A key objective of this paper is to generate tests of the empirical effects of budget deficits on national saving and interest rates and therefore to help distinguish among the three models empirically. We test the Ricardian view against the small open economy and conventional views by estimating the effect on national saving of budget deficits associated with tax reductions, after controlling for government purchases, transfers, marginal tax rates, and other factors. Our empirical results imply that an increase in the budget deficit substantially reduces national saving: specifically, after controlling for other factors, a one-dollar increase in the deficit reduces national saving by between 50 and 80 cents. This suggests that the Ricardian view is not a good approximation to reality.

We then test the small open economy view against the conventional view by examining whether deficits affect interest rates. Our results suggest that the emergence of larger projected budget deficits raises long-term interest rates in the United States. Specifically, we find that a sustained increase in the projected unified deficit equal to 1 percent of GDP raises interest rates by 25 to 35 basis points, ${ }^{4}$ and a sustained increase of that magnitude in the projected primary deficit (the unified deficit excluding interest payments) raises interest rates by 40 to 70 basis points. Indeed, despite a rancorous public debate, there appears to be a surprising degree of convergence in recent estimates of the effects of fiscal policy on interest rates: results from a variety of econometric studies imply that an increase in the unified deficit of 1 percent of GDP, sustained over ten years, would raise interest rates by 30 to 60 basis points. This estimated relationship between deficits and interest rates not only provides further evidence against the Ricardian view, but also implies that the conventional view is a better description of reality for the United States than the small open economy view.

A second objective of the paper is to apply these findings to an analysis of recent and proposed or expected future fiscal policy actions. Under plausible assumptions described below, the unified deficit over the next decade will average about 3.5 percent of GDP. Our estimates imply that such deficits will reduce national saving over that period by between 2 and 3 percent of GDP. Therefore, after ten years, assets held by Americans will be

4. Except where stated otherwise, "deficit" refers to the unified deficit, which includes the deficit or surplus in Social Security and Medicare and net interest payments. 
lower, by 20 to 30 percent of GDP, than they otherwise would be; with a rate of return on capital in the range of 6 percent, this implies that national income will be between 1 and 2 percent lower on an ongoing basis by 2015 . This suggests that current fiscal policy trends will exert a significant drag on future economic performance and living standards. In addition, our estimated interest rate effects imply that making the 2001 and 2003 tax cuts permanent would raise interest rates by enough to raise the cost of capital for new investment even after taking account of the direct effects of the tax cuts, which means that long-term investment and economic growth would fall.

The first section of the paper describes recent historical patterns and current projections for the federal debt, deficits, and their components. The second section provides a framework for evaluating fiscal policy by comparing the three models identified above and by discussing several other ways in which deficits can affect economic performance. The third section provides a preliminary empirical analysis, whose results generally support the conventional view, and gives a sense of the magnitude of the effects of fiscal policy under the conventional approach in a simplified model. The fourth section examines the effects of deficits on aggregate consumption, and the fifth section explores the links between deficits and interest rates. We conclude by discussing some of the implications of our findings.

\section{Fiscal Policy: Trends and Projections}

The federal budget deficit in any year can be measured in a variety of ways; the most appropriate measure is likely to depend on the particular model or application of interest. The most widely used measure, the unified budget balance, is fundamentally a cash-flow metric that includes both the Social Security and the non-Social Security components of the federal budget. To a first approximation, the unified balance shows the extent to which the federal government borrows or lends in credit markets during the year. ${ }^{5}$ For some purposes it is more informative to examine the primary budget balance, which excludes net interest payments. Another

5. The unified budget is not recorded entirely on a cash-flow basis, and so the unified deficit does not precisely match the increase in debt held by the public. For example, only the subsidy cost of direct loan transactions is now recorded in the unified budget. The government must, however, finance the full value of the loan. This factor causes the unified budget deficit to be smaller than the increase in debt held by the public. 
Figure 1. Actual and Standardized Federal Budget Balance, 1962-2004

Percent of potential GDP

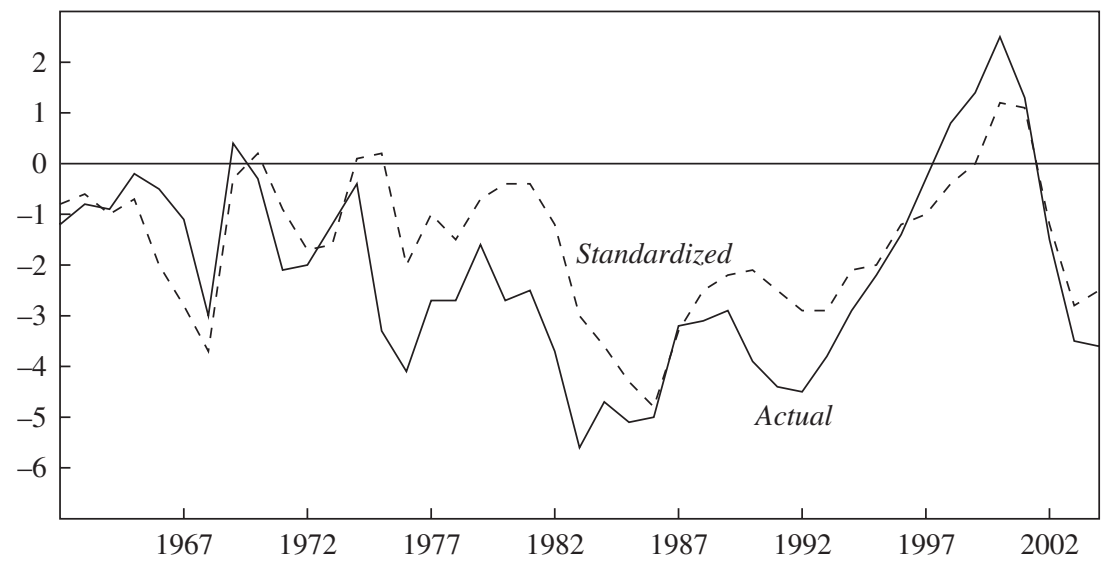

Sources: Congressional Budget Office, "The Cyclically Adjusted and Standardized Budget Measures" (September 2004).

measure, the standardized budget balance, adjusts the unified budget for the business cycle and certain special items. ${ }^{6} \mathrm{We}$ focus primarily on these traditional cash-flow measures. In particular, although we recognize the importance of the implicit debt created by promises of future government benefits, we do not incorporate these promises directly into our analysis, in part because historical time series of this accrued debt are not generally available, and in part because it is unclear how the market and households value this implicit debt relative to the government's explicit debt. ${ }^{7}$

Figure 1 shows the surplus or deficit in the federal unified budget and in the standardized budget, both since 1962, as reported by the Congressional Budget Office (CBO). ${ }^{8}$ Both measures clearly show an increase in the deficit relative to GDP in the early and mid-1980s, a dramatic correction

6. These include losses due to deposit insurance, receipts from auctions of licenses to use the electromagnetic spectrum, timing adjustments, and the contributions of the United States' allies for Operation Desert Storm (the 1991 Gulf war; Congressional Budget Office, "The Cyclically Adjusted and Standardized Budget Measures," September 2004).

7. Auerbach and others (2003) discuss the relationship among the cash-flow measures, accrual accounting, generational accounting, and other ways of measuring the fiscal status of the government. 2004.

8. CBO, "The Cyclically Adjusted and Standardized Budget Measures," September 


\section{Figure 2. Federal Budget Balance, Projected 2004-14a}

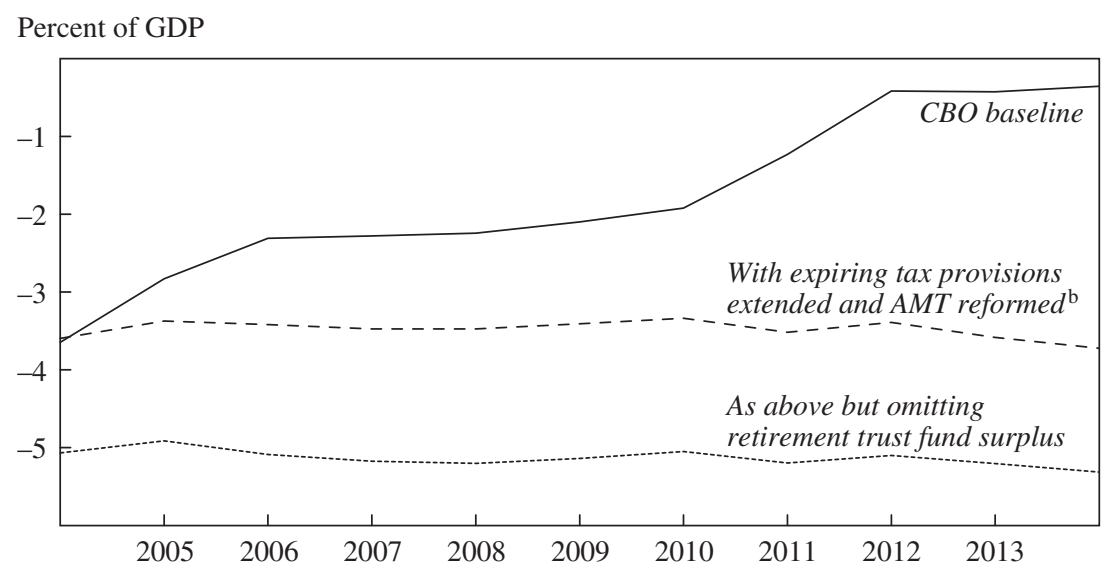

Source: Authors' calculations using Congressional Budget Office, "The Budget and Economic Outlook: An Update" (September 2004), and the TPC Microsimulation Model.

a. Debt service is imputed using the $\mathrm{CBO}$ interest matrix.

b. Assumes that the 2001 and 2003 tax cuts are made permanent and other expiring tax provisions (except the 2002 tax cuts) extended, and that the AMT is indexed for inflation and dependent exemptions are allowed under the AMT.

over the course of the 1990s, and an equally dramatic deterioration since 2000. In fiscal 2004 the unified deficit was 3.6 percent of potential GDP, and the standardized deficit about 2.5 percent. As the figure shows, deficits of this magnitude are large relative to historical norms. Even so, the current budget situation would not be a concern if future fiscal prospects were auspicious. Unfortunately, those prospects are in fact dismal.

The top line in figure 2 shows the CBO's baseline projections for the deficit in the unified budget as of September 2004. ${ }^{9}$ The projections assume that the 2001 and 2003 tax cuts expire as scheduled. Summing the annual projections results in a ten-year baseline unified budget deficit of $\$ 2.3$ trillion, or 1.5 percent of cumulative GDP over that period, for fiscal 2005 to 2014, with the deficits shrinking over time.

This baseline projection is intended to provide a benchmark for legislative purposes. It is explicitly not intended to be a projection of actual or likely budget outcomes or a measure of the financial status of the federal government. ${ }^{10}$ Thus adjustments to the baseline are required to generate a

9. CBO, “The Economic and Budget Outlook," January 2004. 
more plausible budget scenario and to develop more meaningful measures of the government's financial situation. ${ }^{11}$ One concern is that the baseline assumes that all temporary tax provisions expire as scheduled, even though most have been routinely extended in the past. Traditionally, this concern only applied to a small set of policies - such as tax credits for work opportunity or for research and experimentation - that have existed for years, are narrow in scope, and have relatively minor budget costs, and for which extensions occur as a matter of routine. In recent years, however, the distortion created by assuming that all temporary tax provisions will expire as scheduled has grown dramatically, because all of the provisions of the tax cuts in each of the years 2001 through 2004 are scheduled to expire by the end of the decade. These "temporary" provisions are quite different in nature and scope from the other expiring provisions. Whether they will be extended is a major fiscal policy choice, not a matter of routine. ${ }^{12}$

A second concern is that revenue from the alternative minimum tax (AMT) grows dramatically under the baseline, a development that few observers regard as plausible. ${ }^{13}$ Finally, the baseline uses cash-flow accounting, which is appropriate for many programs, but which can distort the financial status of programs whose liabilities increase substantially outside the projection period. ${ }^{14}$

Adjusting for these factors has an enormous impact on the ten-year budget projections. Figure 2 shows that, if the 2001, 2002, and 2003 tax cuts are made permanent, if the other expiring tax provisions are extended, and if the AMT problem is resolved (by indexing the AMT for inflation and allowing dependent exemptions, which would still leave 5 million

10. CBO, "The Economic and Budget Outlook," January 2004.

11. See Auerbach and others (2003) for an extended discussion of these issues.

12. See Gale and Orszag (2003b) for further discussion of the expiring provisions, and Gale and Orszag (2004a) on the effects of making the tax cuts permanent.

13. See Burman, Gale, and Rohaly (2003) for discussion of AMT projections and trends.

14. Another concern is that the baseline holds real discretionary spending constant over time. In a growing economy with an expanding population and evolving security needs, this assumption is not credible. But the September 2004 projections contain offsetting biases for discretionary spending that roughly cancel out. In particular, the baseline includes the recent supplemental spending authority for military expenditures in Iraq, which is unlikely to persist for an entire decade. Removing the supplemental and adjusting the spending level for population results in a ten-year outlay total that is about the same as that in the baseline, and so we simply adopt the official baseline figures for discretionary spending. 


\section{Figure 3. Public Debt, 1950-2014a}

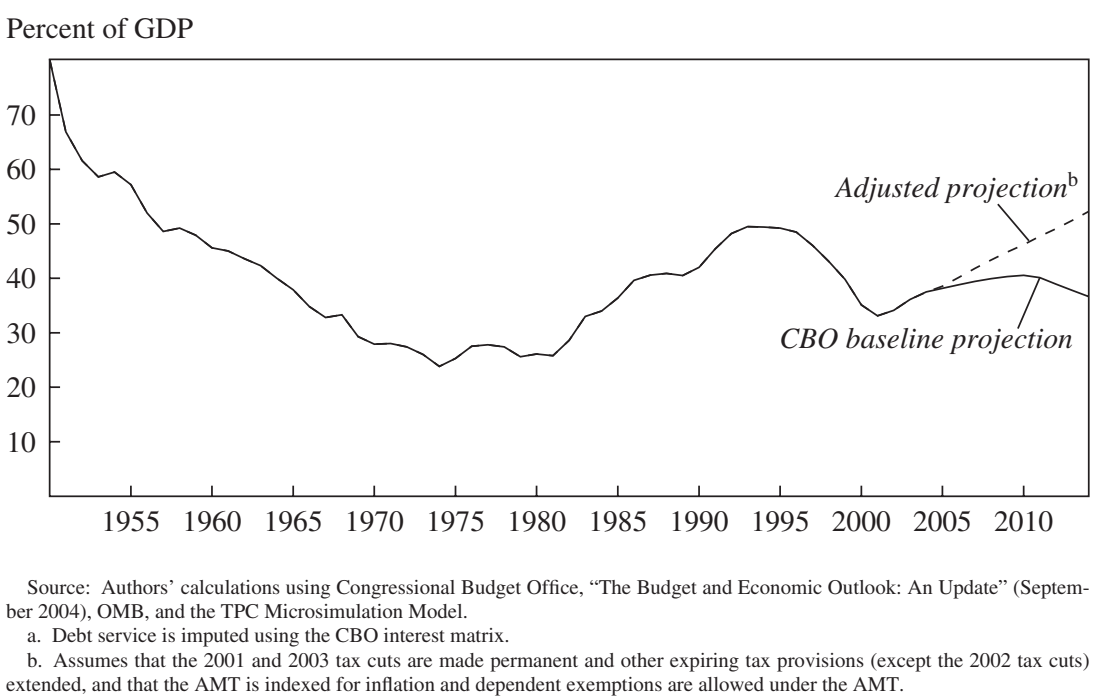

households paying the AMT in 2014), then the adjusted unified budget deficit would remain at approximately 3.5 percent of GDP over the decade and would be 3.7 percent of GDP (almost $\$ 700$ billion) in $2014 . .^{15}$

One way to gauge the implications of the adjusted unified baseline is to examine the implied ratio of public debt to GDP, as is done in figure 3 . Under the adjusted baseline, the debt-GDP ratio would rise steadily throughout the decade and by 2014 would equal 52 percent, well above the most recent high of 49 percent in 1992, and the highest level since 1956. The debt-GDP ratio would continue to rise thereafter.

The ratio of marketable public debt to GDP tells only part of the longterm budget story, however. Social Security, Medicare part A (the hospital insurance program), and government employee pension programs are projected to run surpluses over the next decade but face shortfalls in the long term. One way to control for these effects is to examine the ten-year

15. These figures include the cost of extending the bonus depreciation provision as specified in the 2003 tax law. Some ambiguity surrounds whether this temporary measure will be extended; its extension was not proposed in the administration's fiscal 2005 budget. If this provision were not extended past its sunset at the end of 2004, the deficit over the decade would be about 3 percent of GDP. 
horizon while separating the retirement trust funds from the rest of the budget. For example, the bottom line in figure 2 shows that, omitting the retirement trust funds, the rest of the budget would face deficits of 5.1 percent of GDP over the decade (and 5.3 percent of GDP in 2014) under the assumptions above.

An alternative way to incorporate the entitlement programs is to extend the time horizon of the analysis so that future shortfalls are included. To do this, we report estimates of the fiscal gap, defined as the immediate and permanent increase in taxes or reduction in noninterest expenditure that would be required to establish the same debt-GDP ratio in the long run as holds currently. ${ }^{16}$ In an article co-written with Alan Auerbach, we estimate that, under adjustments similar to those made in figure 2 , the nation faces a longterm fiscal gap in 2004 of 7.2 percent of GDP through 2080 and 10.5 percent of GDP on a permanent basis. ${ }^{17}$ Jagadeesh Gokhale and Kent Smetters have made similar projections, as has the Bush administration. ${ }^{18}$

The main drivers of the fiscal gap, under the above assumptions, are the revenue losses from making the 2001 and 2003 tax cuts permanent and the growth in spending for Medicare, Medicaid, and Social Security. The recent tax cuts, if extended and not eroded over time by the AMT, would cost roughly 2 percent of GDP over the long term. ${ }^{19}$ To help put these figures in context, over the next seventy-five years the actuarial deficit in Social Security is 0.7 percent of GDP under the Social Security trustees' assumptions, and 0.4 percent of GDP under new projections issued by the $\mathrm{CBO} .{ }^{20}$ The deficit in Medicare part A is 1.4 percent of GDP over the next

16. See Auerbach (1994). Over an infinite planning horizon, the requirement is equivalent to assuming that the debt-GDP ratio does not explode. Alternatively, the adjustments set the present value of all future primary surpluses equal to the current value of the national debt, where the primary surplus is the difference between revenue and noninterest expenditure.

17. Auerbach, Gale, and Orszag (2004). In perhaps more familiar terms, the primary deficit would be 4.1 percent of GDP in 2030, 5.5 percent in 2060, and 5.8 percent by 2080; the unified deficit would rise much faster because of accruing interest payments: it would be 13 percent of GDP in 2030, 37 percent by 2060, and 64 percent by 2080. Public debt would be 139 percent of GDP in 2030, 505 percent in 2060, and 942 percent in 2080.

18. Gokhale and Smetters (2003); Office of Management and Budget, Budget of the United States Government: Fiscal Year 2005 Budget.

19. Gale and Orszag (2004a).

20. CBO, "The Outlook for Social Security," June 2004. The actuarial deficit in Social Security over an infinite horizon amounts to 1.2 percent of GDP over that horizon under the trustees' assumptions. 
Figure 4. Entitlement Expenditure under Current Law, 2003 and Projected 2004-80

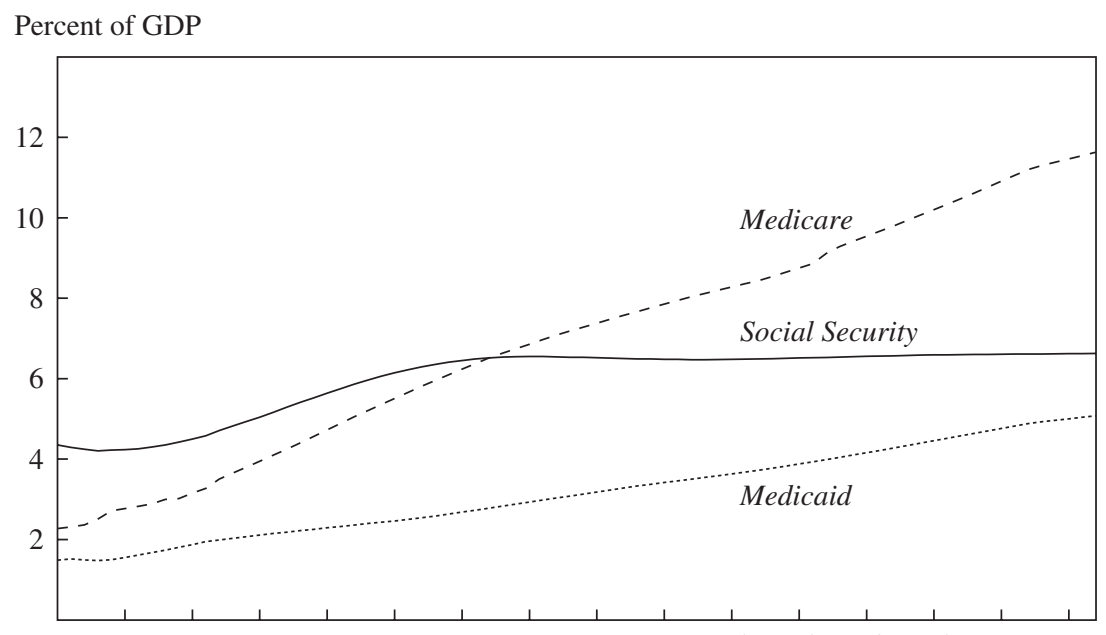

200820132018202320282033203820432048205320582063206820732078

Source: Auerbach, Gale, and Orszag (2004).

seventy-five years under the trustees' assumptions. ${ }^{21}$ Thus, extending the tax cuts would reduce revenue over the next seventy-five years by an amount about as large as the entire shortfall in the Social Security and Medicare part A trust funds over the same period.

Even if the tax cuts are not made permanent, however, the fiscal gap would be 5.1 percent of GDP through 2080 and 8.2 percent on a permanent basis. A primary reason is substantial projected increases in entitlement costs. Figure 4 shows the projected increases in Social Security, Medicare (this time including not only part A but also part B, supplementary Medicare insurance, and part D, the new prescription drug benefit), and federal Medicaid costs as a share of GDP over the long term. ${ }^{22}$ The projected retirement of the baby boomers, ongoing increases in life expectancy, and growth in health care costs per beneficiary in excess of growth in GDP per capita combine to drive federal expenditure on these three programs from 8.1 per-

21. Unlike with Social Security, the CBO has not issued its own fully independent actuarial analysis of Medicare's long-term finances.

22. Auerbach, Gale, and Orszag (2004). Medicaid is not wholly a federal liability; rather, it is financed in part by the states. 
cent of GDP in 2004 to a projected 10.2 percent by $2015,13.3$ percent by 2025 , and 22.7 percent by $2075 .{ }^{23}$ Figure 4 also shows that the vast majority of the growth occurs in the health-related programs, not in Social Security. Indeed, after about 2030, Social Security costs are roughly stable relative to GDP. The health-related programs not only are projected to increase in cost much more dramatically than Social Security but are also much more difficult to reform.

To be sure, substantial uncertainty surrounds these short- and long-term budget projections. Much of the problem stems from the fact that the surplus or deficit is the difference between two large quantities, revenue and spending. Small percentage errors in either can cause large percentage changes in the difference between them. Furthermore, small differences in growth rates sustained for extended periods can have surprisingly large economic effects. Variations in assumed health care cost inflation, in particular, can have a substantial effect on the projections. ${ }^{24}$ Nonetheless, almost all studies that have examined the issue suggest that, even if major sources of uncertainty are accounted for, serious long-term fiscal imbalances will remain..$^{25}$

\section{The Economic Effects of Budget Deficits}

We categorize the effects of budget deficits into two types. What we here call the "traditional" effects are those described in terms of changes in the usual macroeconomic aggregates, such as consumption, saving, and investment, resulting from the linkages among them as described in macroeconomics textbooks. The Ricardian view, the small open economy view, and the "conventional" view of deficits all address these kinds of effects. The "nontraditional" effects include the effects of weakened investor confidence in a country's economic leadership due to increased deficits, the possible threshold effect of a sudden change in investor perceptions of

23. Although it is clear that entitlement spending is a major factor in generating longterm fiscal shortfalls, it is not straightforward to determine how much of the fiscal gap is due to these programs, because to a large extent they are supposed to be funded from general revenue. Auerbach, Gale, and Orszag (2004) examine different ways of decomposing the longterm fiscal gap.

24. CBO, "The Long-Term Budget Outlook," December 2003.

25. For example, see Lee and Edwards (2001) and Shoven (2002). 
the sustainability of a country's deficits, and those effects that go beyond the strictly economic realm, such as the effect of a country's debtor or creditor status on its international power and influence.

\section{Traditional Models}

Figure 5 summarizes the three "traditional" views of deficits, at least as they apply to a deficit created by changes in the timing of a lump-sum tax, holding the path of government purchases constant, as described earlier. Under Ricardian equivalence, private saving rises in response to the deficit by the same amount that government saving falls (that is, by the same amount that the deficit rises); national saving is therefore constant, and no further adjustments are required or expected. ${ }^{26}$

If private saving rises by less than the full amount that public saving falls, then national saving falls, and further adjustments are required to bring national saving and the sum of domestic and net foreign investment back into balance. ${ }^{27}$ If the flow of capital from overseas is infinitely elastic, the entire quantity adjustment occurs through increased capital inflows. In this case net foreign investment declines, but the domestic capital stock remains constant. With no change in the domestic capital stock, domestic output (GDP) is likewise constant. Americans' claims on that output, however, decline because the increased borrowing from abroad must be repaid in the future. In other words, the obligation to repay effectively creates a mortgage against future national income; as a result, future gross national product declines even though gross domestic product is constant. ${ }^{28}$ Because the capital inflow in this example is assumed to be infinitely elastic, inter-

26. Barro (1974).

27. The effects described in response to a change in the deficit would all occur simultaneously. Our ordering of the discussion is intended merely to provide a way of thinking about the channels through which deficits affect the economy. It does not imply or require that the effects occur in any particular order over time.

28. The distinction between domestic investment and net foreign investment is of secondary importance in determining national income (GNP), although it clearly affects domestic income (GDP). Elmendorf and Mankiw (1999, p. 1637) note that, "As long as the returns to wealth are the same at home and abroad, the location of the ... [change in] wealth does not affect our income... Tomorrow's national output and income depend on today's national saving, wherever this saving is ultimately invested." They also note several caveats to this statement, including differences in the tax implications of investment abroad relative to investment at home, and implications for income distribution. 
Figure 5. Theoretical Responses to a Change in the Budget Deficit

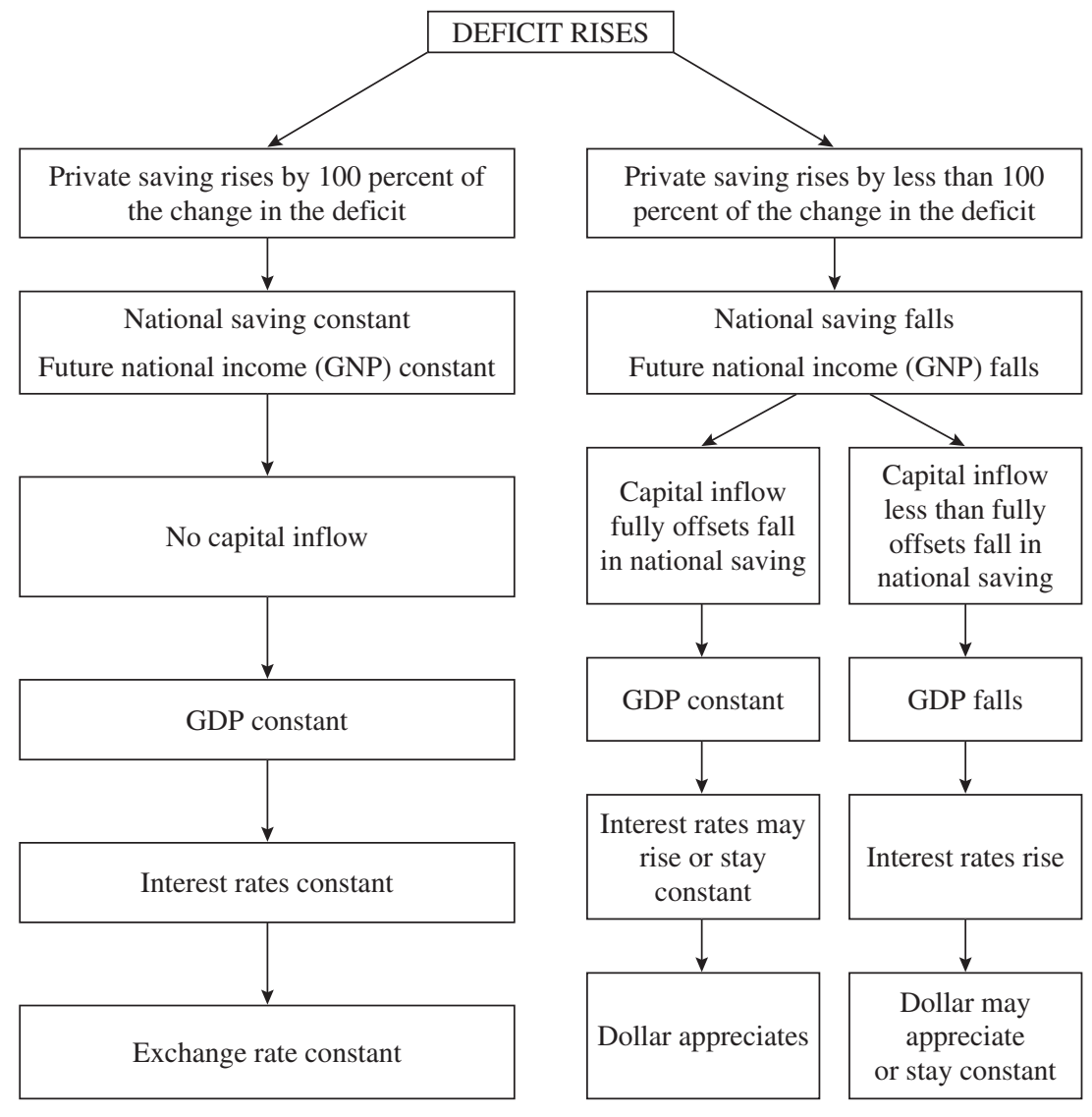

Ricardian equivalence

Small open economy Conventional view

est rates do not change. Even so, larger deficits reduce future national income (GNP). We refer to this scenario as the small open economy view.

A third possibility is that the supply of international capital is not infinitely elastic. In this case, if national saving falls in response to an increased budget deficit, the relative price and quantity adjustments are different than under the small open economy model, but the end result-a decline in future national income-remains the same. In the absence of perfect capital mobility, the reduction in national saving implies a shortage of funds to finance 
investment, given existing interest rates and exchange rates. That imbalance puts upward pressure on interest rates, as firms compete for the limited pool of funds to finance investment. The increase in interest rates serves to reduce domestic investment. In a closed economy, the entire adjustment to the reduction in national saving would occur through reduced domestic investment. In an open economy with imperfect capital mobility, the decline in national saving and the resulting rise in interest rates induce some combination of a decline in domestic investment and a decline in net foreign investment (that is, an increase in capital inflows). These changes must be sufficient to ensure that the change in national investment equals the change in national saving. Following Douglas Elmendorf and Gregory Mankiw, we refer to this scenario as the conventional view. ${ }^{29}$

\section{Nontraditional Effects}

Beyond their traditional effects on national saving, future national income, and interest rates, deficits can affect the economy in other ways. For example, increased deficits may cause investors to gradually lose confidence in U.S. economic leadership. As Edwin Truman emphasizes,${ }^{30}$ a substantial fiscal deterioration over the longer term may cause "a loss of confidence in the orientation of US economic policies." Such a loss in confidence could then put upward pressure on domestic interest rates, as investors demand a higher risk premium on dollar-denominated assets. The costs of current account deficits - which are in part induced by large budget deficits - may even extend beyond the economic costs narrowly defined. Benjamin Friedman notes that, "World power and influence have historically accrued to creditor countries. It is not coincidental that America emerged as a world power simultaneously with our transition from a debtor nation . . . to a creditor supplying investment capital to the rest of the world." 31

Both the traditional models and the analysis of nontraditional effects focus on gradual negative effects from reduced national saving. This focus may be too limited, however, in that it ignores the possibility of much more sudden and severe adverse consequences. ${ }^{32}$ In particular, the

29. Elmendorf and Mankiw (1999).

30. Truman (2001).

31. Friedman (1988, p. 76).

32. Rubin, Orszag, and Sinai (2004). 
traditional analysis of budget deficits in large advanced economies does not seriously entertain the possibility of explicit default, or of implicit default through high inflation. ${ }^{33}$ If market expectations regarding the avoidance of default were to change and investors had difficulty seeing how the policy process could avoid extreme measures, the consequences could be much more sudden and severe than traditional estimates suggest. The role of financial market expectations in this type of scenario is central. One of the principal ways in which such a "hard landing" could be triggered is if investors begin to doubt whether a country will maintain its strong historical commitment to avoiding high inflation in order to reduce the real value of the public debt. As Laurence Ball and Mankiw note,

We can only guess what level of debt will trigger a shift in investor confidence, and about the nature and severity of the effects. Despite the vagueness of fears about hard landings, these fears may be the most important reason for seeking to reduce budget deficits ... as countries increase their debt, they wander into unfamiliar territory in which hard landings may lurk. If policymakers are prudent, they will not take the chance of learning what hard landings in G-7 countries are really like. ${ }^{34}$

Although we do not explicitly incorporate nontraditional effects in our analysis below, they serve as an important reminder of why budget deficits, especially chronic deficits, could exert large adverse effects on U.S. economic performance. Our focus on traditional effects is certainly justifiable in the context of a historical analysis of postwar data from the United States. That does not imply, however, that ignoring such issues is appropriate when examining the likely impacts of future deficits. The nation has never before faced the prospect of deficits that are large, sustained, and indeed likely to grow over many decades.

33. The traditional view also suggests that either the exchange rate would stay constant or the currency would appreciate in response to the inflow of capital from abroad. The sign of the exchange rate change, however, is unclear in the presence of changes in a country-specific risk premium. If that premium increases as a country's net international indebtedness (or flow of new international borrowing) increases, the country's currency could depreciate. In other words, although nontraditional effects are likely to accentuate the impact of deficits on interest rates, they may alter even the sign of the exchange rate dynamics.

34. Ball and Mankiw (1995, p. 117). 
Figure 6. Net National Saving and Net Federal Saving, 1950-2003

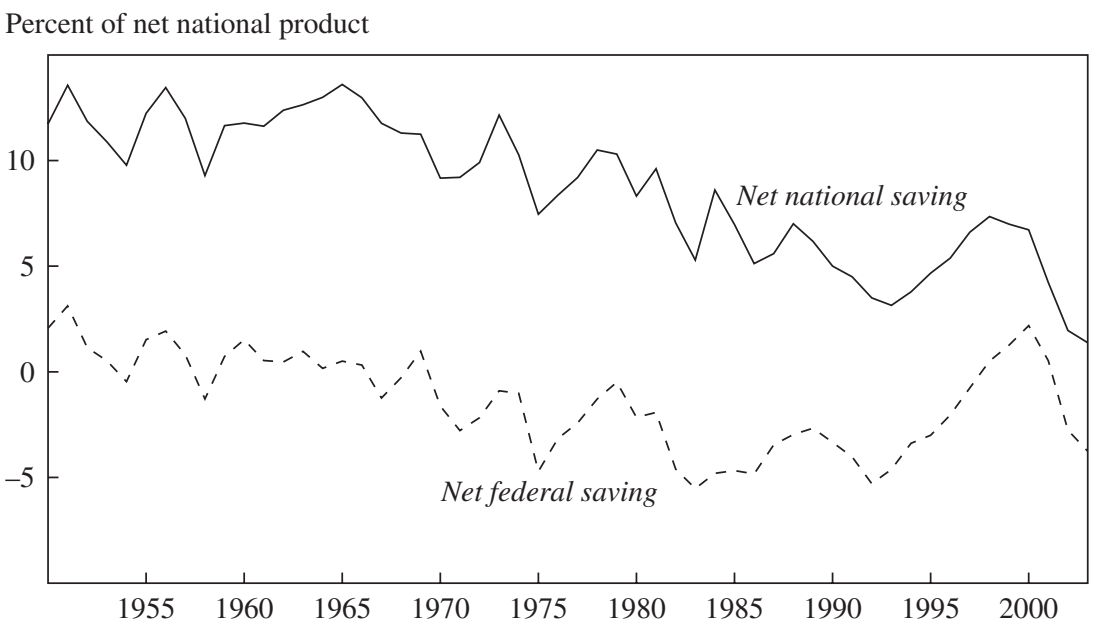

Source: Bureau of Economic Analysis, National Income and Product Accounts.

\section{Preliminary Evidence and Benchmark Calculations}

The first part of this section sets up the later analysis of deficits, national saving, and interest rates by providing prima facie evidence of the relationships among them that are consistent with the conventional view but hard to reconcile with the small open economy view or the Ricardian view. The second part then provides some benchmark calculations that give a sense of the magnitudes involved.

\section{A Preliminary Examination of the Data}

Figure 6 shows net national saving and net federal government saving as shares of net national product (NNP) since $1950 .{ }^{35}$ Federal saving has fluctuated significantly over time, and this variation is visibly correlated

35. Net national saving is defined as gross saving minus depreciation of the capital stock and is taken from the National Income and Product Accounts, table 5.1, line 2. Net federal saving is defined as gross federal saving minus depreciation on the federal government's physical capital stock and is taken from the same table, line 11. 
Figure 7. Net Domestic Investment and Net National Saving, 1950-2003

Percent of net national product

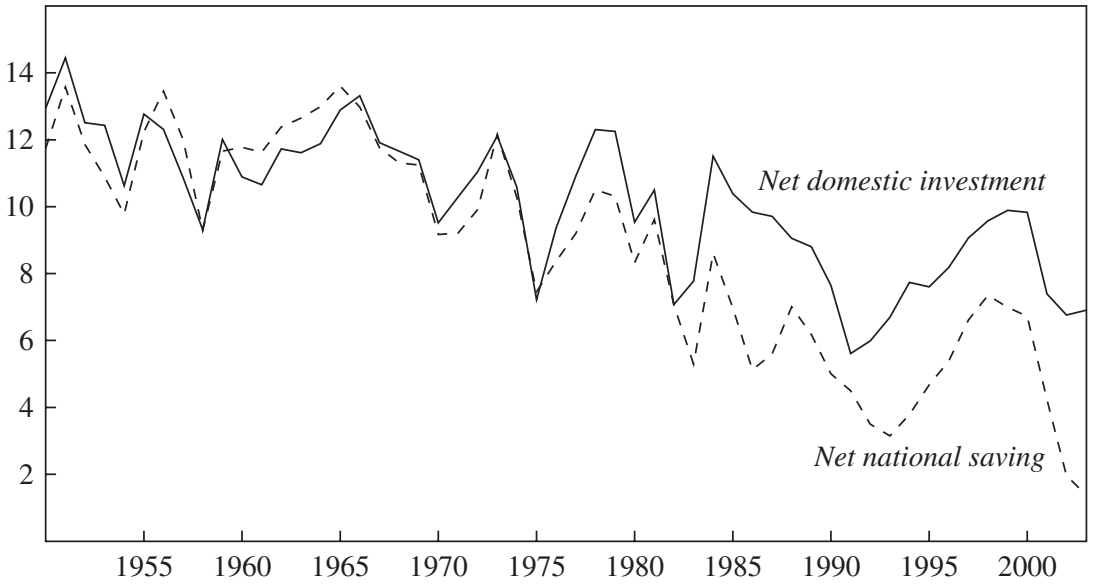

Source: Bureau of Economic Analysis, National Income and Product Accounts.

with swings in national saving. The correlation is especially apparent in the last two decades. The two series both rise moderately in the mid-1980s, decline from the late 1980s to the early 1990s, rise significantly during the 1990s, and then decline again over the past few years. Over the whole period, a regression of national saving on federal saving (each expressed as a share of NNP) yields a coefficient of $1.02(t=7)$, and an equivalent first-differences regression (regressing changes in the national saving-NNP ratio on changes in the federal saving-NNP ratio) yields a coefficient of $0.86(t=9){ }^{36}$

Figure 7 shows net national saving and net domestic investment since 1950, again as shares of NNP. ${ }^{37}$ The two series follow very similar patterns over time. Domestic investment has declined by less than national saving over the past twenty years and has exceeded national saving in every year since the early 1980s. The difference is reflected in chronic current account

36. Both regressions include a constant term, as do those mentioned in the next two paragraphs.

37. Net domestic investment is equal to gross investment minus depreciation of the capital stock and is taken from the National Income and Product Accounts, table 5.1, line 31. 
deficits (not shown) and a substantial decline in the nation's net international investment position. ${ }^{38}$ Over the past few years, the decline in national saving has been much sharper than the decline in net domestic investment. Between 1998 and 2003, national saving declined by 6 percent of NNP, with about half of the decline made up by increased capital inflows, and half by reduced net domestic investment. A regression of the net domestic investment-NNP ratio on the net national saving-NNP ratio yields a coefficient of $0.57(t=15)$. When the regression is performed on first differences of the two measures, the coefficient is $0.83(t=10){ }^{39}$

Figure 8 plots annual observations of the projected five-year-ahead real ten-year interest rate on Treasury bonds against the CBO's projections of the unified federal deficit as a share of GDP five years ahead. ${ }^{40}$ Figure 9 shows similar observations for real forward long-term rates and projections of the publicly held debt. Both figures show a clear association between projected fiscal policy outcomes and forward long-term real interest rates. A regression of the two series in figure 8 implies that an increase in the projected deficit by 1 percent of GDP is associated with an increase in the forward rate of about 27 basis points $(t=5)$.

Figures 6 through 9 suggest a very simple story: Increases in current federal budget deficits significantly reduce net national saving. This reduction in national saving is reflected partly in increased borrowing from abroad and partly in reduced net domestic investment. Increases in projected future federal deficits raise long-term interest rates, which explains how reductions in national saving serve to reduce domestic investment. These patterns are consistent with the conventional view, but not with the Ricardian or the small open economy view. A primary goal of the paper is to see how robust these simple relationships are to more formal analysis.

38. The current account, as defined by the "net lending" series published by the Bureau of Economic Analysis, ran a small surplus in 1991, in part because of capital account transactions related to the Gulf war and in part because of a large statistical discrepancy. On a current-cost basis, the United States has gone from being the world's largest creditor nation in 1980, with a net international investment position (NIIP) of 13 percent of GDP, to the world's largest debtor nation, with an NIIP of about -22 percent of GDP at the end of 2003. On a market-value basis, the NIIP was 7 percent of GDP in 1982, falling to -24 percent at the end of 2003 (Bureau of Economic Analysis, National Income and Product Accounts, table $1.1 .5,2004)$.

39. The positive correlation between domestic saving and domestic investment mirrors the findings of a long line of research initiated by Feldstein and Horioka (1980).

40. The data in the figure are described in more detail later in the paper. 
Figure 8. Forward Ten-Year Real Treasury Rates and Projected Deficits, 1976-2004a

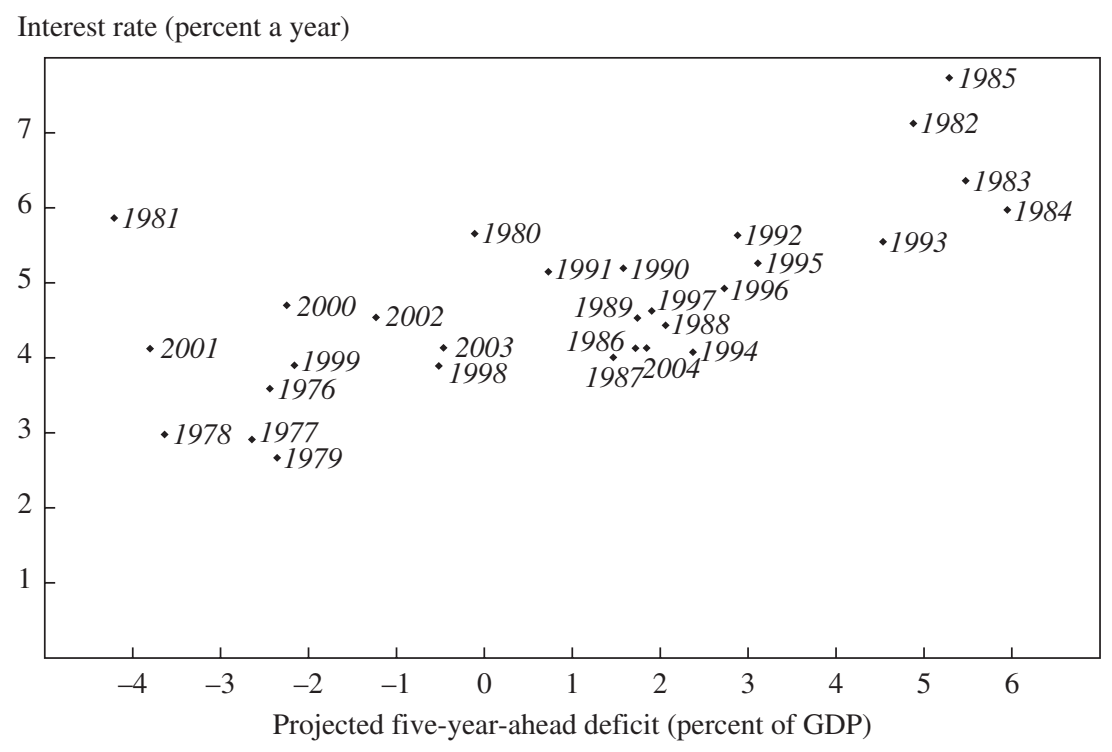

Source: Laubach (2003)

a. Projected deficits as constructed by Laubach (2003).

\section{The Magnitude of Conventional Effects in Two Simplified Models}

To generate some intuition about the potential magnitudes involved in the conventional approach, we examine the impact of budget deficits in two simplified models. Before turning to these models, however, we must first address a key issue: If fiscal policy does influence interest rates, does it do so through changes in government deficits (what we call the "flow perspective") or through changes in the government debt (the "stock perspective")? According to Eric Engen and Glenn Hubbard, ${ }^{41}$ government debt rather than deficits should affect the level of interest rates. However, since many models (including the IS-LM model widely taught to undergraduates) imply that budget deficits affect interest rates, we take a broader view. Throughout this paper we leave open the possibility that either the stock perspective or the flow perspective may be valid. In this section we there-

41. Engen and Hubbard (2004). 
Figure 9. Forward Ten-Year Real Treasury Rates and Projected Debt, 1976-2004a

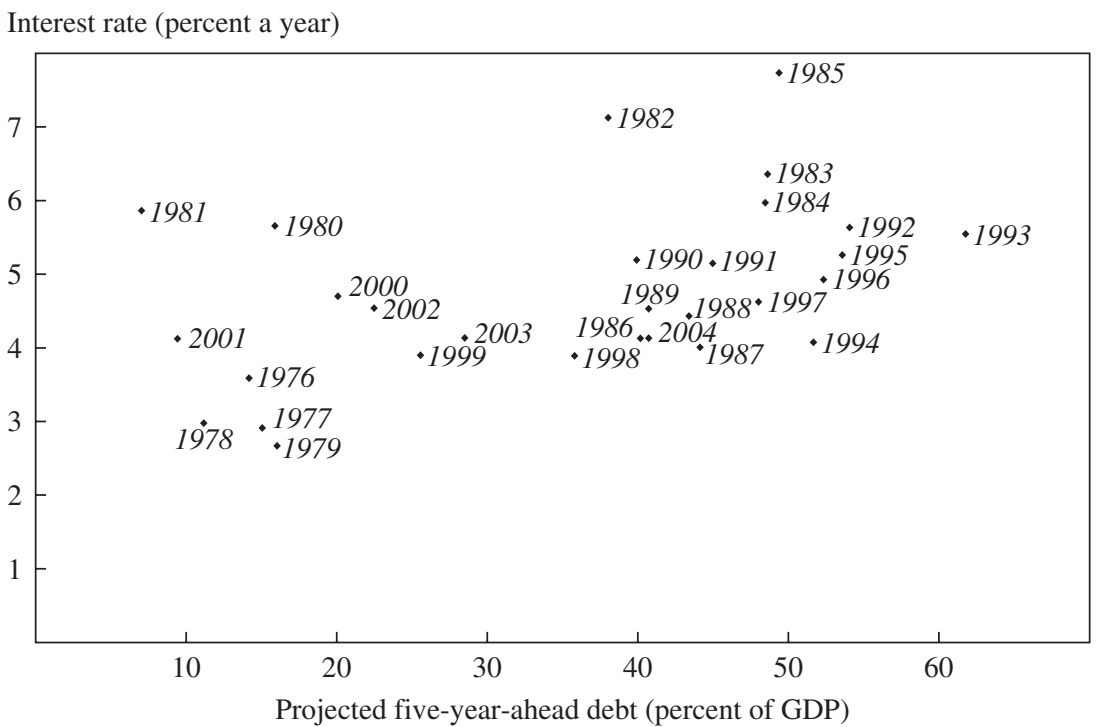

Source: Laubach (2003).

a. Projected debt as constructed by Laubach (2003).

fore undertake two related calibration exercises. One focuses on the impact of the deficit in a Solow model of economic growth, and the other on the impact of debt in a highly stylized steady-state exercise.

First, we follow Matthew Shapiro and examine the effects of sustained budget deficits in the context of the Solow growth model.$^{42}$ Following Mankiw, ${ }^{43}$ we assume that the economy's growth rate (the sum of the rate of population growth and that of output per worker) is equal to 3 percent a year, the depreciation rate is 4 percent a year, and the capital share of output is 30 percent. We also assume that the initial gross national saving rate is 17.5 percent of output. ${ }^{44}$ This level for the saving rate could, for example, reflect a private gross saving rate of 20 percent of output and a unified budget deficit of 2.5 percent, which are the values we assume for

42. Shapiro (2004).

43. Mankiw (2000a, p. 123).

44. Mankiw assumes a capital-output ratio of 2.5 and then solves for the saving rate. The implied saving rate is 17.5 percent. 
Table 1. Steady-State Effects of an Increased Budget Deficit in the Solow Growth Model Percent except where stated otherwise

\begin{tabular}{lcccc}
\hline & & \multicolumn{3}{c}{$\begin{array}{c}\text { Value in new steady state following } \\
\text { increase in deficit of 1 percent of output, } \\
\text { offset by private saving as indicated }\end{array}$} \\
\cline { 3 - 5 } Parameter & $\begin{array}{c}\text { Assumed } \\
\text { initial } \\
\text { value }\end{array}$ & $\begin{array}{c}\text { Offset }=25 \\
\text { percent }\end{array}$ & $\begin{array}{c}\text { Offset }=0 \\
\text { percent }\end{array}$ & $\begin{array}{c}\text { Offset }=50 \\
\text { percent }\end{array}$ \\
\hline Capital share of output & 30.0 & 30.0 & 30.0 & 30.0 \\
Annual depreciation rate & 4.0 & 4.0 & 4.0 & 4.0 \\
Annual GDP growth rate & 3.0 & 3.0 & 3.0 & 3.0 \\
National saving as share of GDP & 17.5 & 16.75 & 16.5 & 17.0 \\
Private saving as share of GDP & 20.0 & 20.25 & 20.0 & 20.5 \\
Budget deficit as share of GDP & 2.5 & 3.5 & 3.5 & 3.5 \\
Income per capita & 1.48 & 1.45 & 1.44 & 1.46 \\
Capital-output ratio & 2.5 & 2.39 & 2.36 & 2.43 \\
Marginal product of capital & 12.0 & 12.5 & 12.7 & 12.4 \\
\hline
\end{tabular}

Source: Authors' calculations.

illustrative purposes. These assumptions generate an initial steady state with a capital-output ratio of 2.5 and a gross marginal product of capital of 12 percent, which are reasonable values for the United States (table 1).

Now assume that the unified budget deficit rises by 1 percent of output on a sustained basis. ${ }^{45}$ Suppose that one-quarter of this decline in public saving is offset by an increase in private saving. ${ }^{46} \mathrm{With}$ this response, private saving rises to 20.25 percent of output, and the national saving rate declines to 16.75 percent. Given the reduction in national saving, output per capita in the new steady state is reduced by 1.9 percent. The marginal product of capital is 54 basis points higher. If we assume that the change

45. Note that this simplified model does not impose a government budget constraint. As a result, we do not have to specify how the tax cut is paid for.

46. This private saving response is somewhat larger than might be expected based on the data patterns in figure 6, but it is within the range of the econometric estimates we report below. It is also roughly consistent with the calculations undertaken by the Council of Economic Advisers (Economic Report of the President, 2003) in the Bush administration, which reports that a one-dollar increase in the deficit reduces the domestic capital stock by about 60 cents. The Council's scenario could occur, for example, if a one-dollar increase in the deficit causes private saving to rise by 25 cents (the effect we assume) and international capital flows offset an additional 15 cents of the decline in national saving. Dennis and others (2004) make similar assumptions about private saving and capital flow offsets in modeling the macroeconomy. See Feldstein and Horioka (1980) and Dornbusch (1991) for analyses of the relationship between capital inflows and national saving. 
in the interest rate at which government borrows is equal to the change in the marginal product of capital, the implication is that the increase in the unified budget deficit raises the interest rate by 54 basis points.

These results provide one way of calibrating the traditional effects of changes in the budget deficit. Under our base case assumptions, holding other factors constant, a sustained increase in the unified deficit of 1 percent of GDP reduces output by about 2 percent and raises interest rates by about 50 basis points. If half of the decline in public saving, rather than onequarter, is offset by an increase in private saving, long-term output per capita would decline by 1.2 percent and interest rates would rise by 35 basis points. If there is no private saving response, output per capita would fall by 2.5 percent, and the marginal product of capital would rise by 73 basis points. (Table 1 summarizes these results.)

The Solow model exercise underscores the somewhat arbitrary nature of choosing between the stock and flow perspectives described above: In the steady state of the Solow model, deficits and debt are linked, making it difficult to assert that one variable rather than the other is the one that influences interest rates. Nonetheless, since our Solow analysis was presented in terms of the flow variable (the deficit), we also undertake a closely related exercise framed in terms of the stock variable (government debt). In steady state the debt-GDP ratio is equal to the unified deficit-GDP ratio divided by the GDP growth rate. ${ }^{47}$ Assuming a 3 percent growth rate as in the Solow model exercise above, an increase in the unified deficit-GDP ratio of 1 percent of GDP would thus raise the steady-state debt-GDP ratio by approximately 33 percentage points.

To map this increase in the debt-GDP ratio into a change in income and interest rates, we follow the basic contours of the "debt fairy" calculation in Ball and Mankiw. ${ }^{48}$ First, as in the Solow model above, we assume that the initial steady state for the economy involves a capitaloutput ratio of 2.5. The change in the ratio depends on how much of the debt increase is offset by increased private capital accumulation; we assume a 25 percent offset. (Because of depreciation, the 25 percent capital offset is a slightly different concept from the 25 percent saving off-

47. If the unified deficit is a constant share $k$ of GDP, then $(r D+p) / Y=k$, where $r$ is the interest rate, $D$ is government debt, $p$ is the primary budget balance, and $Y$ is GDP. A constant debt-GDP ratio requires that $D$ grow at rate $g$, or that $(r D+p) / D=g$, where $g$ is the growth rate of $Y$. Therefore, in a steady state with a constant debt-GDP ratio, $D / Y=k / g$.

48. Ball and Mankiw (1995). 
set assumed in the Solow model, and so the results presented here differ slightly from the Solow model results.) The reduction in capital is thus equal to 25 percent $(=33 \times 0.75)$ of initial GDP. Assuming a marginal product of capital equal to 12 percent, the reduction in the capital stock causes income to decline by about 3 percent. Second, to map the change in the capital-output ratio into a change in the marginal product of capital, a specific form of the aggregate production function is necessary. With a Cobb-Douglas production function, the percentage increase in the marginal product of capital is equal to the percentage decline in the capitaloutput ratio. The capital-output ratio falls by 7 percent, from 2.50 to 2.32 . The marginal product of capital would thus rise by 7 percent, from 12.0 to 12.8. Finally, we again assume that the change in the long-term government borrowing rate is equal to the change in the marginal product of capital. The result is that income declines by 3 percent, and steady-state long-term interest rates increase by about 80 basis points.

Since these two exercises are quite closely related despite their different framing in terms of deficits and debt, it is not surprising that the results are basically similar. A sustained increase in the unified deficit equal to 1 percent of GDP reduces income by 2 to 3 percent and raises long-term interest rates by roughly 50 to 80 basis points under the base case assumptions. ${ }^{49}$

To be sure, it is challenging to move from these simplified models to real-world results. For one thing, the models assume a closed economy, whereas the U.S. economy is large and open. One would therefore expect capital inflows to mitigate the interest rate and domestic production effects to some degree, even though the effect on national income should be largely unaffected by the assumption of a closed economy. In our view, however, these exercises not only help to calibrate the potential magnitude of the effects of deficits and debt on income and interest rates, but also underscore the shortcomings in ruling out the stock (debt) or the flow (deficit) perspective a priori.

Another key consideration is that the results above consider only the effects of increased budget deficits or debt per se. A full analysis of the effects of public policies on economic growth should take into account not only the effects of increased deficits and debt, but also the direct effects of the increases in spending programs or reductions in taxes that cause them. The effects of fiscal policies on both economic performance and interest

49. As noted in the text, the small differences reflect the treatment of depreciation. 
rates depend not only on the deficit but also on the specific elements of the policies generating that deficit. For example, a dollar spent on public investment projects would increase the unified budget deficit by one dollar, but the net effect on future income would depend on whether the return on those investment projects exceeded the return on the private capital that would have instead been financed by the national saving crowded out by the deficit. Similarly, a deficit of 1 percent of GDP caused by reducing marginal tax rates will generally have different implications for both national income and interest rates than a deficit of 1 percent of GDP caused by increasing government purchases of goods and services. We return to this issue in the concluding section.

\section{Deficits and Consumption}

Our goal in this section is to measure the effects of fiscal policy on consumption and thus to distinguish the Ricardian view from the other two views. A wide variety of research tends to reject various indirect implications of Ricardian equivalence. For example, previous studies have generally found that motives for bequests are neither universal nor purely altruistic, that consumer spending responds to temporary tax cuts, that only current and not anticipated changes in income affect consumption (although there is mixed evidence on this point), and that aggregate consumption is sensitive to the age distribution of the population. ${ }^{50}$

We focus on a different set of tests: those using aggregate time-series data to examine the impact of tax revenue on consumption, holding other factors constant. Despite the numerous rejections of Ricardian equivalence in the indirect tests noted above, the time has come to revisit the aggregate time-series effects of fiscal policy on consumption, for several reasons. First, these analyses provide a direct test of whether the timing of tax collections affects the economy, controlling for other factors. Second, the aggregate time-series tests measure the magnitude of the effects in question. This is particularly important because virtually no one claims that Ricardian equivalence is literally true. Rather, the controversy is over the extent to which Ricardian equivalence is a good approximation

50. See, for example, the discussions in Bernheim (1987), Elmendorf and Mankiw (1999), and Seater (1993). 
of the aggregate impact of fiscal policies. The indirect tests noted above can be helpful in distinguishing whether the literal implications of Ricardian equivalence hold, but they are often uninformative about the quantitative importance of any particular rejection of the theory. Third, there has been little work on these issues using data beyond the early 1990s. The past ten years, however, have witnessed dramatic shifts in fiscal policy in both directions (figures 1 and 6 ). These shifts have raised the prominence of policy concerns about budget deficits and should provide useful variation from an econometric perspective. Fourth, despite the rejection of many of the indirect implications of Ricardian equivalence noted above, some lines of research using aggregate time-series data have proved more favorable to the Ricardian view. This may be due to problems that are unique to time-series analysis, but it may also be that Ricardian equivalence is more robust—in particular as a working approximation-than the indirect tests suggest.

\section{Previous Research}

The authors of earlier literature surveys have noted the wide variety of research findings from studies of aggregate consumption and fiscal policy and emphasize the daunting econometric problems inherent in such studies, but they come to different conclusions about what the literature shows. Robert Barro, and Elmendorf and Mankiw, conclude that the literature is inconclusive. ${ }^{51}$ John Seater concludes that, once the studies are corrected for econometric problems, Ricardian equivalence is corroborated, or at least cannot be rejected. ${ }^{52}$ Douglas Bernheim concludes that, once the studies are normalized appropriately, Ricardian equivalence should be rejected..$^{53}$

Previous studies of the effects of fiscal policy on consumption have taken three general approaches. A variety of studies undertake reducedform analysis of consumption and saving patterns in the United States and other countries. ${ }^{54}$ Like figures 6 and 7 above, these studies generally appear to support non-Ricardian interpretations of the data.

51. Barro (1989); Elmendorf and Mankiw (1999).

52. Seater (1993).

53. Bernheim (1989).

54. See, for example, Summers (1985), Carroll and Summers (1987), Poterba and Summers (1986, 1987), and Serres and Pelgrin (2003). 
A second, and by far the largest, strand of the literature specifies consumption functions and then tests for the effects of fiscal policy given the consumption function. ${ }^{55}$ Perhaps the best-known research in this area is that by Roger Kormendi and Philip Meguire, who find no evidence of nonRicardian effects..$^{56}$

A third strand of the literature focuses on Euler equation tests. David Aschauer examines the effects of fiscal policy assuming utility maximization and rational expectations, but his model does not nest a non-Ricardian specification. ${ }^{57}$ Fred Graham and Daniel Himarios nest Ricardian and nonRicardian views in a model that builds on work by Fumio Hayashi; they find non-Ricardian results using a nonlinear instrumental variables estimation procedure. ${ }^{58}$ Paul Evans and Iftekhar Hasan estimate an empirical

55. Feldstein (1982); Seater and Mariano (1985); Kormendi (1983).

56. Kormendi (1983); Kormendi and Meguire (1986, 1990, 1995). A comprehensive review of the literature following Kormendi (1983) is beyond the scope of this paper, but some highlights include the following. Barth, Iden, and Russek (1986) update the data, correct some data problems, and obtain results broadly similar to those of Kormendi (1983). Modigliani and Sterling (1986) argue that Kormendi's results are flawed because of data problems, a failure to distinguish between temporary and permanent taxes, and inappropriate first-differencing of the data. They develop an aggregate consumption function derived from the life-cycle model that contains Ricardian equivalence as a special case. Their empirical results show strongly non-Ricardian results. Kormendi and Meguire (1986) note significant problems with how Modigliani and Sterling have defined temporary taxes. They show that imposing the condition that taxes and transfers have effects of equal magnitude and opposite sign (as Modigliani and Sterling do) is not supported by the data, and that when that restriction is relaxed, taxes and government debt continue to have Ricardian effects. Feldstein and Elmendorf (1990) work within the Kormendi framework and evaluate the effects of removing the war years, extending the sample, introducing other specification changes, and instrumenting for endogenous explanatory variables. After reproducing Kormendi's estimates, they find that their extensions fundamentally alter the findings, and they obtain very strong nonRicardian results. Kormendi and Meguire (1990), however, show that Feldstein and Elmendorf's results obtain only as the joint consequence of using what Kormendi and Meguire view as the wrong deflators and failing to incorporate the improved definitions of variables that came out of the 1986 exchanges. Graham (1995) makes two adjustments to the Kormendi and Meguire framework, extended to 1991. He allows state and local variables to have different effects than federal variables. He also claims that theory suggests that labor and capital income should have distinct effects, and he proposes a decomposition of aggregate income and taxes into those due to labor and those due to capital. His reestimates suggest some non-Ricardian results, but not for tax revenue. Kormendi and Meguire (1995) challenge the decomposition of income into labor and capital and show that an alternative definition generates Ricardian results. Meguire $(1998,2003)$ continues research in this vein.

57. Aschauer (1985); see also Bernheim (1987) and Graham and Himarios (1991).

58. Graham and Himarios (1991); Hayashi (1982). 
version of a model due to Olivier Blanchard, which nests Ricardian and non-Ricardian alternatives, and obtain results consistent with Ricardian equivalence. ${ }^{59}$ Graham and Himarios correct several data and econometric problems in Evans' work and find strong non-Ricardian effects. ${ }^{60}$

The relative value of the consumption function and Euler equation approaches is a recurring theme in the literature. The advantage of using the Euler equation approach is that Ricardian equivalence requires a combination of utility maximization and rational expectations that the Euler equation can explicitly incorporate. The disadvantage is that Euler equation models can (and do) fail for reasons unrelated to Ricardian equivalence, and Ricardian equivalence can fail in ways that do not affect the Euler equation. ${ }^{61}$ Marjorie Flavin argues that the consumption function approach is fundamentally inconsistent with Ricardian equivalence and therefore cannot be used to test the theory. ${ }^{62}$ On the other hand, the strongest evidence in favor of Ricardian equivalence comes from the consumption function studies by Kormendi and Meguire. ${ }^{63}$ Rather than attempt to resolve this debate, we estimate both consumption function and Euler equation models. We also show that the two specifications are closely related, so that the differences between the resulting estimated equations may not be large, even though the conceptual frameworks are quite different.

\section{Specifying the Consumption Function}

Our specification of the consumption function replicates, updates, and extends the work by Kormendi and Meguire and their critics. Kormendi specifies an aggregate consumption function of the following form: ${ }^{64}$

$$
\begin{aligned}
C_{t}= & \alpha_{0}+\alpha_{11} Y_{t}+\alpha_{12} Y_{t-1}+\alpha_{2} G S_{t}+\alpha_{3} W_{t-1}+\alpha_{4} T R_{t} \\
& +\alpha_{5} T X_{t}+\alpha_{6} R E_{t}+\alpha_{7} G I N T_{t}+\alpha_{8} G B_{t-1}+\varepsilon_{t},
\end{aligned}
$$

where $t$ indexes time periods; $C$ is a measure of consumption; $Y$ is net national product; $G S$ is government purchases of goods and services; $W$ is a measure of private net worth, not including government debt; $T R$ is government transfer payments; $T X$ is tax revenue; $R E$ is corporate retained

59. Evans (1988, 1993); Evans and Hasan (1994); Blanchard (1985).

60. Graham and Himarios (1996).

61. Bernheim (1987),

62. Flavin (1987).

63. Kormendi (1983); Kormendi and Meguire (1986, 1990).

64. Kormendi (1983). 
earnings; GINT is government interest payments; and $G B$ is the value of outstanding government debt. ${ }^{65}$

RICARDIAN AND NON-RICARDIAN HYPOTHESES. Although equation 1 is not specified in a structural manner, Kormendi argues that this framework nests both Ricardian and non-Ricardian hypotheses. ${ }^{66}$ The Ricardian view is that consumption depends on current wealth, expected future income, and the burdens imposed by government purchases. If current and lagged NNP serve as proxies for future income, then the expected coefficients on NNP and lagged NNP should be between zero and one. Likewise, in this formulation, the coefficient on wealth represents the marginal propensity to consume out of wealth. Current government purchases are included as a proxy for expected future government purchases. The non-Ricardian view embodied in the equation is that consumption depends on disposable income, wealth, and government bonds. Note that disposable income is given by $Y+T R-T X-R E+G I N T$.

The central tests between the Ricardian and the non-Ricardian view have to do with the coefficients on current taxes and current transfers. Ricardian equivalence implies that $\alpha_{4}=\alpha_{5}=0$, that is, that transfers and taxes should not affect consumption, given the path of government purchases. The values of these coefficients, if they are not zero, provide a quantitative measure of the extent to which Ricardian equivalence fails as a description of reality. The coefficients on the two variables may be different from each other if transfers and taxes generally accrue to groups with different consumption patterns.

Ricardian equivalence also implies that $\alpha_{8}=0$, that is, that consumers do not treat government bonds as net wealth. Although this channel for non-Ricardian effects has attracted an enormous amount of attention over the past several decades, it is unlikely to prove useful in distinguishing Ricardian and non-Ricardian views, for several reasons. First, it is unlikely to be the major channel through which non-Ricardian effects occur. James Poterba and Lawrence Summers, as well as Evans, show that, if Ricardian equivalence is violated solely because forward-looking, life-cycle consumers treat government bonds completely as net worth, the effects of fis-

65. National saving equals NNP less government purchases and private consumption. Therefore, because the regression controls for NNP and government purchases, the effect of tax revenue on national saving is simply the inverse of the effect of tax revenue on consumption.

66. Kormendi (1983). 
cal policy on short-run consumption are likely to be small. ${ }^{67}$ In addition, as discussed further below, there are both data and conceptual problems with interpreting the government bond and wealth variables. As a result, we do not emphasize this channel for testing between the different models. ${ }^{68}$

Unfortunately, the coefficient on government spending does not provide a test of Ricardian equivalence. Ricardian equivalence is a statement about how variations in the timing of taxation affect private consumption, holding expected government purchases constant. It has no necessary implications for the effects of government purchases on private consumption, since the items the government purchases could be substitutes or complements for private consumption. ${ }^{69}$ Thus, although it is important to control for expected government purchases, the coefficient on the purchases variable does not provide information that can test the theory. ${ }^{70}$

DATA. All of the variables are first transformed into real per capita levels. ${ }^{71}$ To deal with stationarity issues, Kormendi and Meguire, and Martin Feldstein and Elmendorf, estimate regressions in first differences of the levels of the variables and in first differences of their ratios to NNP per capita. ${ }^{72}$ Following John Campbell and Mankiw, ${ }^{73}$ we also adjust for stationarity a third way, by dividing the first differences in the levels by lagged NNP per capita. ${ }^{74}$

67. Poterba and Summers (1987); Evans (1991).

68. The coefficients on government interest payments and retained earnings should be zero under Ricardian equivalence, but this test is not particularly interesting, because these coefficients should also be zero under other hypotheses. For example, the view that households pierce the corporate veil suggests that retained earnings should not affect consumption. Likewise, if government interest payments accrue mainly to high-income households who tend to save the funds, they will not affect consumption.

69. Kormendi (1983) obtains a negative coefficient on government purchases and interprets this finding as evidence in favor of Ricardian equivalence. Kormendi and Meguire (1990), however, acknowledge that the coefficient on government spending is essentially uninformative in testing Ricardian and non-Ricardian views.

70. There is an inconsistency in the specification in that current levels of government purchases are intended to proxy for permanent levels, but current levels of taxes and transfers are intended to represent levels that may well be altered in the future.

71. Details of the data construction may be found at www.brookings.edu/es/commentary/ journals/bpea-macro/2004_2_bpea.consumptiondata.pdf or obtained from the authors on request.

72. Kormendi and Meguire (1990); Feldstein and Elmendorf (1990).

73. Campbell and Mankiw (1990).

74. Campbell and Mankiw (1990) divide by lagged disposable income rather than NNP, but the difference is unimportant empirically in our specifications. We divide by NNP in order to maintain consistency with the first-difference-in-ratios specification. 
We use two measures of consumption. The first is the one developed by Kormendi: expenditure on nondurables and services, plus 10 percent of current durable expenditures, plus 30 percent of the existing stock of durable goods, all per capita. ${ }^{75}$ The second measure is nondurables plus services, a more common measure used in many studies of aggregate consumption. ${ }^{76}$

The wealth variable used by Kormendi and Meguire and others in this literature is an amalgam of different series, with several extrapolations. We instead use data on household wealth from the Federal Reserve Board's Flow of Funds reports. We use household rather than private sector net worth, because the household measure includes the market value of corporate equities held by households, whereas the private sector measure instead uses book values of corporate equity. Since we want to capture the influence of wealth on consumption, we believe that the market value of equities is the more appropriate measure to include. Note, however, that the data for private sector bonds are reported on a book-value basis in the Flow of Funds accounts.

For data on the market value of federal government bonds, we use information from the Federal Reserve Bank of Dallas. For state debt we use the same methodology as Seater, ${ }^{77}$ but we include more recent data. Generally, the data under the new definitions track the data under the old definitions very closely for the years in which values of both are present. ${ }^{78}$

With these adjustments, we have nearly the same specification employed by Kormendi and Meguire. ${ }^{79}$ In earlier work we almost exactly replicate their results for earlier time periods dating from as far back as 1931 up to $1992 .{ }^{80}$

EXTENDING THE KORMENDI-MEGUIRE APPROACH. Our analysis here focuses on three extensions of this framework. First, we extend the sample

75. Kormendi (1983).

76. Graham (1992) and Graham and Himarios (1996) discuss the importance of alternative consumption measures in testing Ricardian equivalence.

77. Seater (1981).

78. The data from the Federal Reserve Bank of Dallas appear to have been derived using the same procedures as those developed in Cox (1985). The market value of state debt is calculated by multiplying the outstanding par value of state and local bonds (taken from the Statistical Abstract of the United States) by the ratio of market to par value for municipal bonds (taken from Standard and Poor's, 2003).

79. Kormendi (1983); Kormendi and Meguire (1986, 1990, 1995).

80. Gale and Orszag (2003c). 
period to 2002. The added ten years of data provide valuable variation in fiscal policy and national saving.

Second, we alter the treatment of government taxes and transfers. In the Kormendi-Meguire specification, all government variables (taxes, transfers, purchases, interest payments, and debt) represent combined values for federal, state, and local governments. But federal and state fiscal variables are likely to have different effects on aggregate consumption. Perhaps most important, the states collect a significant share of their revenue through consumption taxes; this revenue would be expected to vary positively with consumption, whereas revenue from other taxes would be expected, at least in non-Ricardian theory, to vary negatively. In addition, the states face balanced budget rules. The cyclical dynamics of changes in state taxes or spending may therefore be different than for federal taxes or spending, which implies that the behavioral response to such changes might be different. The balanced budget rules also imply that state debt may be paid off at a different rate than federal debt, which again could influence behavior. Likewise, to the extent that state and local taxes are capitalized into local real estate prices, they are likely to have different effects than federal taxes.$^{81}$ For all of these reasons, testing for differences in the effects of federal and state taxes is a reasonable specification check.

Third, in some specifications we include as control variables estimates of marginal tax rates on labor income and capital income. Not controlling for marginal tax rates may bias the coefficient on tax revenue. Changes in tax revenue that also entail changes in tax rates create both substitution and income effects for current consumers. Even in a Ricardian world, changes in marginal tax rates will induce shifts in consumption and labor supply behavior. Therefore, in order to isolate the effects of changes in tax revenue, a control for tax rates is required. Several authors emphasize the potential importance of the confounding effects of not controlling for marginal tax rates; ${ }^{82}$ its importance is buttressed by the work of Kenneth Judd and of Alan Auerbach and Laurence Kotlikoff, who show that the

81. Another issue is that state and federal governments typically allocate their purchases of goods and services differently: a large share of federal purchases goes to defense, whereas state purchases are dedicated more to education, police, and health care. Finally, mobility across states is much higher than emigration out of the United States; the basic Ricardian story does not hold when individuals (and their offspring) can escape the future burden of taxation by moving.

82. Barro (1989); Bernheim (1989); Plosser (1987b). 
short-term dynamics of tax cuts are strongly affected by private responses to marginal tax incentives. ${ }^{83}$ Despite all of these considerations, however, almost all previous studies of Ricardian equivalence omit marginal tax rates from their regressions; an exception is the study by Seater and Roberto Mariano, and even they omit corporate tax rates. ${ }^{84}$

For the marginal tax rate on labor income we use a measure constructed by the Treasury Department, which represents the combined marginal tax rate due to income and payroll taxes on a four-person family with twice the median income, all of which comes from wages. (We use twice median income, rather than median income, to capture the fact that significantly more than half of all earnings accrue to those who earn more than the median.) Our capital income tax rate is the average, economy-wide, marginal effective tax rate on new capital investment. ${ }^{85}$ An advantage of these series is that most of the variation in them stems from legislative changes in tax rules rather than from changes in macroeconomic aggregates.

\section{Consumption Function Results}

Table 2 shows ordinary least squares (OLS) results for the specification described above. We estimate regressions for three time periods, two measures of consumption, three transformations of the dependent and independent variables, and three specifications of the explanatory variables.

The first panel of table 2 reports results from regressions that follow the Kormendi and Meguire specification of explanatory variables ${ }^{86}$ The first three columns report estimates of equations in which the variables are entered as first differences of their levels; the second column of this group shows that, when the sample is restricted to 1954-92, consumption does not respond to changes in taxes in a statistically significant fashion. This finding replicates and confirms the basic Kormendi and Meguire estimates. The first column, however, shows that merely updating the data through 2002 alters the conclusion, even with no further changes in specification. In this regression the coefficient on the tax variable implies that, controlling for other factors, between 27 and 39 percent of a tax cut is spent in the year it occurs; the Ricardian benchmark would be zero, and the pure Keynesian

83. Judd (1985, 1987a, 1987b); Auerbach and Kotlikoff (1987). In contrast, Seater (1993) suggests that any bias arising from the omission of marginal tax rates is not important.

84. Seater and Mariano (1985).

85. These data are from Gravelle (2004).

86. Kormendi and Meguire (1990). 
Table 2. Consumption Function OLS Estimates of the Effects of Taxes on Aggregate Consumption ${ }^{\mathrm{a}}$

\begin{tabular}{|c|c|c|c|c|c|c|c|c|c|}
\hline \multirow[b]{2}{*}{ Dependent variable } & \multicolumn{3}{|c|}{$\begin{array}{l}\text { Variables entered as first } \\
\text { differences of levels }\end{array}$} & \multicolumn{3}{|c|}{$\begin{array}{l}\text { Variables entered as first differences } \\
\text { of ratios to NNP per capita }\end{array}$} & \multicolumn{3}{|c|}{$\begin{array}{l}\text { Variables entered as first differences } \\
\text { of levels, scaled to NNP per capita }\end{array}$} \\
\hline & 1956-2002 & 1954-92 & 1954-2000 & $1956-2002$ & 1954-92 & $1954-2000$ & $1956-2002$ & 1954-92 & $1954-200$ \\
\hline \multicolumn{10}{|c|}{ Regressions using Kormendi-Meguire specification of independent variables } \\
\hline $\begin{array}{l}\text { Kormendi measure of } \\
\text { consumption }^{\mathrm{b}}\end{array}$ & $\begin{array}{l}-0.39 \\
(-0.14)\end{array}$ & $\begin{array}{l}-0.14 \\
(0.16)\end{array}$ & $\begin{array}{l}-0.23 \\
(0.17)\end{array}$ & $\begin{array}{c}-0.22 \\
(0.13)\end{array}$ & $\begin{array}{c}-0.09 \\
(0.15)\end{array}$ & $\begin{array}{c}-0.19 \\
(0.14)\end{array}$ & $\begin{array}{c}-0.24 \\
(0.12)\end{array}$ & $\begin{array}{c}-0.14 \\
(0.14)\end{array}$ & $\begin{array}{c}-0.23 \\
(0.13)\end{array}$ \\
\hline $\begin{array}{l}\text { Expenditure on nondurables } \\
\text { and services }{ }^{c}\end{array}$ & $\begin{array}{c}-0.27 \\
(0.12)\end{array}$ & $\begin{array}{c}-0.15 \\
(0.16)\end{array}$ & $\begin{array}{c}-0.23 \\
(0.16)\end{array}$ & $\begin{array}{l}-0.18 \\
(0.13)\end{array}$ & $\begin{array}{l}-0.10 \\
(0.15)\end{array}$ & $\begin{array}{l}-0.18 \\
(0.14)\end{array}$ & $\begin{array}{l}-0.21 \\
(0.12)\end{array}$ & $\begin{array}{l}-0.15 \\
(0.14)\end{array}$ & $\begin{array}{l}-0.22 \\
(0.13)\end{array}$ \\
\hline \multicolumn{10}{|c|}{ As above but entering federal taxes and state and local taxes separately ${ }^{\mathrm{d}}$} \\
\hline $\begin{array}{l}\text { Kormendi measure } \\
\text { of consumption }\end{array}$ & $\begin{array}{l}-0.46 \\
(0.13)\end{array}$ & $\begin{array}{c}-0.21 \\
(0.16)\end{array}$ & $\begin{array}{c}-0.30 \\
(0.16)\end{array}$ & $\begin{array}{c}-0.28 \\
(0.12)\end{array}$ & $\begin{array}{c}-0.17 \\
(0.15)\end{array}$ & $\begin{array}{c}-0.26 \\
(0.13)\end{array}$ & $\begin{array}{c}-0.31 \\
(0.11)\end{array}$ & $\begin{array}{c}-0.25 \\
(0.12)\end{array}$ & $\begin{array}{c}-0.31 \\
(0.12)\end{array}$ \\
\hline $\begin{array}{l}\text { Expenditure on nondurables } \\
\text { and services }\end{array}$ & $\begin{array}{c}-0.34 \\
(0.11)\end{array}$ & $\begin{array}{l}-0.23 \\
(0.16)\end{array}$ & $\begin{array}{c}-0.29 \\
(0.14)\end{array}$ & $\begin{array}{l}-0.25 \\
(0.11)\end{array}$ & $\begin{array}{c}-0.20 \\
(0.14)\end{array}$ & $\begin{array}{c}-0.26 \\
(0.12)\end{array}$ & $\begin{array}{c}-0.27 \\
(0.11)\end{array}$ & $\begin{array}{c}-0.27 \\
(0.12)\end{array}$ & $\begin{array}{l}-0.31 \\
(0.12)\end{array}$ \\
\hline \multicolumn{10}{|c|}{ As above but also including marginal tax rates ${ }^{\mathrm{d}}$} \\
\hline $\begin{array}{l}\text { Kormendi measure of } \\
\text { consumption }\end{array}$ & $\begin{array}{c}-0.46 \\
(0.14)\end{array}$ & $\begin{array}{l}-0.15 \\
(0.15)\end{array}$ & $\begin{array}{l}-0.26 \\
(0.17)\end{array}$ & $\begin{array}{l}-0.34 \\
(0.13)\end{array}$ & $\begin{array}{l}-0.22 \\
(0.14)\end{array}$ & $\begin{array}{l}-0.30 \\
(0.13)\end{array}$ & $\begin{array}{l}-0.34 \\
(0.12)\end{array}$ & $\begin{array}{l}-0.24 \\
(0.13)\end{array}$ & $\begin{array}{l}-0.33 \\
(0.13)\end{array}$ \\
\hline $\begin{array}{l}\text { Expenditure on nondurables } \\
\text { and services }\end{array}$ & $\begin{array}{l}-0.34 \\
(0.12)\end{array}$ & $\begin{array}{l}-0.18 \\
(0.15)\end{array}$ & $\begin{array}{c}-0.27 \\
(0.15)\end{array}$ & $\begin{array}{l}-0.30 \\
(0.12)\end{array}$ & $\begin{array}{l}-0.25 \\
(0.15)\end{array}$ & $\begin{array}{l}-0.30 \\
(0.13)\end{array}$ & $\begin{array}{l}-0.30 \\
(0.11)\end{array}$ & $\begin{array}{l}-0.26 \\
(0.14)\end{array}$ & $\begin{array}{c}-0.32 \\
(0.13)\end{array}$ \\
\hline
\end{tabular}

Source: Authors' regressions using data from Bureau of Economic Analysis, National Income and Product Accounts; Gravelle (2004); Department of the Treasury; Federal Reserve; U.S. Census Bureau; an Standard and Poor's.

a. Table reports regression coefficients on the tax revenue variable in equation 1 in the text. Numbers in parentheses are robust standard errors.

b. Real consumption per capita of nondurables and services, plus 10 percent of expenditure on durable goods, plus 30 percent of the stock of durable goods (Kormendi, 1983).

c. Real expenditure per capita on nondurables and services multiplied by the sample-period mean ratio of total consumption expenditure to nondurable and services expenditure.

d. Coefficients are for the effect of federal taxes only. Data on marginal tax rates on capital and labor are unavailable before 1956. 
benchmark would be close to 100 percent. These conclusions are not particularly sensitive to the starting point for the data (results not shown), but they are sensitive to the ending date: the third column shows that the statistical significance of the tax coefficient depends on whether 2001 and 2002 are included. This sensitivity to the last two years of the data is not present when the specification is improved, as shown below. The remaining columns in the first panel report results of different transformations of the dependent variable and show similar although smaller effects.

The middle panel splits the federal and state tax variables, for the reasons noted above. This has several effects on the results. First, the absolute values of the coefficients and the associated $t$ statistics on federal taxes are larger than were the corresponding values for all taxes in the first panel. For the period 1954 through 2002, the estimates suggest that between 25 and 46 cents of every dollar in federal tax cuts is consumed in the first year, controlling for other factors. Second, the statistical significance of the results is no longer sensitive to whether the last two years are included. Third, although the results are not shown, the coefficients on the state tax variables are positive, large, and precisely estimated. This buttresses the view that federal and state taxes can have different effects on the economy, and it points out an important source of aggregation bias (between federal and state tax revenue) in previous work on this subject. ${ }^{87}$

The regressions reported in the bottom panel of table 2 again split the tax variables into their federal and state components but also include the variables for marginal tax rates on labor income and capital income. Their inclusion has only a small effect on the estimated coefficients.

Table 3 reports the coefficient estimates for the six regressions in the bottom panel of table 2 that cover the full sample period (1956-2002). Several results are worth highlighting. The coefficients on NNP and lagged NNP are similar to those reported by Kormendi and Meguire. ${ }^{88}$ Government purchases enter with a small, positive, statistically insignificant coefficient. ${ }^{89}$ The contrast between the effects of federal and state taxes is stark. State taxes enter with a positive coefficient that hovers around 1.0, whereas the

87. The results are similar when all the fiscal variables, not just taxes, are split into federal and state components (not shown).

88. Kormendi and Meguire (1990).

89. In Gale and Orszag (2003c) we show that, in earlier periods, the coefficient on the purchases variable is larger and precisely estimated, consistent with other results in the literature. 
Table 3. OLS Coefficient Estimates for All Independent Variables in the Consumption Function ${ }^{\mathrm{a}}$

\begin{tabular}{|c|c|c|c|c|c|c|}
\hline \multirow[b]{2}{*}{ Independent variable } & \multicolumn{2}{|c|}{$\begin{array}{l}\text { Variables measured as first } \\
\text { differences of levels }\end{array}$} & \multicolumn{2}{|c|}{$\begin{array}{c}\text { Variables measured as first } \\
\text { differences of ratios to NNP } \\
\text { per capita }\end{array}$} & \multicolumn{2}{|c|}{$\begin{array}{l}\text { Variables measured as first } \\
\text { differences of levels, scaled } \\
\text { to NNP per capita }\end{array}$} \\
\hline & $\begin{array}{l}\text { Kormendi } \\
\text { consumption } \\
\text { measure }\end{array}$ & $\begin{array}{l}\text { Nondurables } \\
\text { and services } \\
\text { expenditure }\end{array}$ & $\begin{array}{l}\text { Kormendi } \\
\text { consumption } \\
\text { measure }\end{array}$ & $\begin{array}{l}\text { Nondurables } \\
\text { and services } \\
\text { expenditure }\end{array}$ & $\begin{array}{l}\text { Kormendi } \\
\text { consumption } \\
\text { measure }\end{array}$ & $\begin{array}{l}\text { Nondurables } \\
\text { and services } \\
\text { expenditure }\end{array}$ \\
\hline Current-period NNP & $\begin{array}{c}0.36 \\
(0.08)\end{array}$ & $\begin{array}{c}0.33 \\
(0.07)\end{array}$ & $\begin{array}{c}3.41 \\
(0.96)\end{array}$ & $\begin{array}{c}3.05 \\
(0.92)\end{array}$ & $\begin{array}{c}0.27 \\
(0.06)\end{array}$ & $\begin{array}{c}0.31 \\
(0.06)\end{array}$ \\
\hline Lagged NNP & $\begin{array}{c}0.13 \\
(0.05)\end{array}$ & $\begin{array}{l}0.08 \\
(0.04)\end{array}$ & $\begin{array}{l}0.08 \\
(0.04)\end{array}$ & $\begin{array}{l}0.07 \\
(0.03)\end{array}$ & $\begin{array}{l}0.04 \\
(0.04)\end{array}$ & $\begin{array}{l}0.03 \\
(0.04)\end{array}$ \\
\hline Government purchases & $\begin{array}{c}0.15 \\
(0.15)\end{array}$ & $\begin{array}{c}0.10 \\
(0.12)\end{array}$ & $\begin{array}{c}0.11 \\
(0.11)\end{array}$ & $\begin{array}{c}0.07 \\
(0.10)\end{array}$ & $\begin{array}{c}0.08 \\
(0.10)\end{array}$ & $\begin{array}{c}0.06 \\
(0.10)\end{array}$ \\
\hline Federal taxes & $\begin{array}{l}-0.46 \\
(0.14)\end{array}$ & $\begin{array}{l}-0.34 \\
(0.12)\end{array}$ & $\begin{array}{l}-0.34 \\
(0.13)\end{array}$ & $\begin{array}{l}-0.30 \\
(0.12)\end{array}$ & $\begin{array}{l}-0.34 \\
(0.12)\end{array}$ & $\begin{array}{l}-0.30 \\
(0.11)\end{array}$ \\
\hline State and local taxes & $\begin{array}{c}0.88 \\
(0.49)\end{array}$ & $\begin{array}{c}0.99 \\
(0.41)\end{array}$ & $\begin{array}{c}0.85 \\
(0.37)\end{array}$ & $\begin{array}{l}1.00 \\
(0.35)\end{array}$ & $\begin{array}{c}0.92 \\
(0.37)\end{array}$ & $\begin{array}{c}0.98 \\
(0.35)\end{array}$ \\
\hline Government transfers & $\begin{array}{c}0.76 \\
(0.29)\end{array}$ & $\begin{array}{c}0.52 \\
(0.25)\end{array}$ & $\begin{array}{c}0.56 \\
(0.19)\end{array}$ & $\begin{array}{c}0.55 \\
(0.18)\end{array}$ & $\begin{array}{c}0.26 \\
(0.26)\end{array}$ & $\begin{array}{c}0.25 \\
(0.24)\end{array}$ \\
\hline Government interest paid & $\begin{array}{c}0.08 \\
(0.31)\end{array}$ & $\begin{array}{c}0.15 \\
(0.26)\end{array}$ & $\begin{array}{c}0.06 \\
(0.26)\end{array}$ & $\begin{array}{c}0.24 \\
(0.25)\end{array}$ & $\begin{array}{l}-0.06 \\
(0.27)\end{array}$ & $\begin{array}{c}0.09 \\
(0.25) \\
\text { (continued) }\end{array}$ \\
\hline
\end{tabular}


Table 3. OLS Coefficient Estimates for All Independent Variables in the Consumption Functiona (continued)

\begin{tabular}{|c|c|c|c|c|c|c|}
\hline \multirow[b]{2}{*}{ Independent variable } & \multicolumn{2}{|c|}{$\begin{array}{l}\text { Variables measured as first } \\
\text { differences of levels }\end{array}$} & \multicolumn{2}{|c|}{$\begin{array}{c}\text { Variables measured as first } \\
\text { differences of ratios to NNP } \\
\text { per capita }\end{array}$} & \multicolumn{2}{|c|}{$\begin{array}{c}\text { Variables measured as first } \\
\text { differences of levels, scaled } \\
\quad \text { to NNP per capita }\end{array}$} \\
\hline & $\begin{array}{l}\text { Kormendi } \\
\text { consumption } \\
\text { measure }\end{array}$ & $\begin{array}{l}\text { Nondurables } \\
\text { and services } \\
\text { expenditure }\end{array}$ & $\begin{array}{l}\text { Kormendi } \\
\text { consumption } \\
\text { measure }\end{array}$ & $\begin{array}{l}\text { Nondurables } \\
\text { and services } \\
\text { expenditure }\end{array}$ & $\begin{array}{l}\text { Kormendi } \\
\text { consumption } \\
\text { measure }\end{array}$ & $\begin{array}{l}\text { Nondurables } \\
\text { and services } \\
\text { expenditure }\end{array}$ \\
\hline Lagged government debt & $\begin{array}{l}-0.03 \\
(0.02)\end{array}$ & $\begin{array}{l}-0.03 \\
(0.02)\end{array}$ & $\begin{array}{l}-0.03 \\
(0.02)\end{array}$ & $\begin{array}{l}-0.02 \\
(0.02)\end{array}$ & $\begin{array}{c}-0.02 \\
(0.02)\end{array}$ & $\begin{array}{c}-0.02 \\
(0.02)\end{array}$ \\
\hline Lagged wealth & $\begin{array}{c}0.02 \\
(0.01)\end{array}$ & $\begin{array}{c}0.02 \\
(0.01)\end{array}$ & $\begin{array}{c}0.01 \\
(0.01)\end{array}$ & $\begin{array}{c}0.01 \\
(0.01)\end{array}$ & $\begin{array}{c}0.01 \\
(0.01)\end{array}$ & $\begin{array}{c}0.01 \\
(0.01)\end{array}$ \\
\hline Corporate retained earnings & $\begin{array}{c}0.10 \\
(0.16)\end{array}$ & $\begin{array}{c}0.06 \\
(0.14)\end{array}$ & $\begin{array}{c}0.08 \\
(0.15)\end{array}$ & $\begin{array}{c}0.06 \\
(0.14)\end{array}$ & $\begin{array}{c}0.01 \\
(0.00)\end{array}$ & $\begin{array}{c}0.00 \\
(0.00)\end{array}$ \\
\hline Marginal tax rate on capital ${ }^{\mathrm{b}}$ & $\begin{array}{c}1.03 \\
(0.65)\end{array}$ & $\begin{array}{c}1.08 \\
(0.55)\end{array}$ & $\begin{array}{c}0.06 \\
(0.03)\end{array}$ & $\begin{array}{c}0.06 \\
(0.03)\end{array}$ & $\begin{array}{c}0.06 \\
(0.03)\end{array}$ & $\begin{array}{c}0.07 \\
(0.03)\end{array}$ \\
\hline Marginal tax rate on labor ${ }^{b}$ & $\begin{array}{l}-1.39 \\
(0.71)\end{array}$ & $\begin{array}{l}-1.45 \\
(0.59)\end{array}$ & $\begin{array}{l}-0.06 \\
(0.03)\end{array}$ & $\begin{array}{l}-0.06 \\
(0.03)\end{array}$ & $\begin{array}{l}-0.06 \\
(0.03)\end{array}$ & $\begin{array}{c}-0.07 \\
(0.03)\end{array}$ \\
\hline Constant & $\begin{array}{c}0.06 \\
(0.05)\end{array}$ & $\begin{array}{c}0.07 \\
(0.04)\end{array}$ & $\begin{array}{c}0.00 \\
(0.00)\end{array}$ & $\begin{array}{c}0.00 \\
(0.00)\end{array}$ & $\begin{array}{c}0.00 \\
(0.00)\end{array}$ & $\begin{array}{c}0.01 \\
(0.00)\end{array}$ \\
\hline
\end{tabular}

Source: Authors' regressions using data from Bureau of Economic Analysis, National Income and Product Accounts; Gravelle (2004); Department of the Treasury; Federal Reserve; U.S. Census Bureau; and Standard and Poor's.

a. Table reports regression coefficients for all independent variables in the regressions using 1956-2002 data in the bottom panel of table 2. Numbers in parentheses are robust standard errors. Number of observations $N=47$. All lags are one-period lags. Consumption measures are as defined in table 2.

b. Both the coefficient and the standard error are multiplied by 100 . 
coefficient on federal taxes is always negative; both coefficients are significantly different from zero. Government transfers raise consumption, and the effect is statistically different from zero in most of the specifications. ${ }^{90}$ The marginal tax rate on capital enters with a positive coefficient, whereas the marginal tax rate on labor enters with a negative coefficient. Both effects are plausible and are economically small. Private wealth enters with a small, positive, but imprecisely estimated effect, and government bonds with a small, negative, but imprecisely estimated effect. ${ }^{91}$

In summary, these results demonstrate that, within the framework that supporters of Ricardian equivalence have viewed as providing the most credible evidence in their favor, updated data and an improved specification reveal robust non-Ricardian effects: in these specifications about 30 to 46 cents of every dollar in federal tax cuts is spent in the same year.

Nevertheless, there are significant concerns with this set of specifications. Most notably, the equations are not derived explicitly from a welldefined economic model, and many of the key explanatory variables are likely to be endogenous. Although one can use instrumental variables techniques to address concerns about endogeneity, such an effort raises special problems in the consumption function approach, ${ }^{92}$ and the specification contains a very large number of potentially endogenous variables. For these reasons we turn to Euler equations, which we estimate in both OLS and instrumental variables forms.

\section{Specifying the Euler Equation}

This section develops an Euler equation specification that nests Ricardian and non-Ricardian alternatives. In the standard specification, under the permanent-income hypothesis, consumers adjust their consumption in each

90. In the regressions that exclude the marginal tax rates, the transfers coefficient is always large, positive, and statistically significant.

91. We examined several alternative specifications, none of which affected the results in any important way. First, to account for the fact that Ricardian consumers should care about expected future government purchases, not just current purchases, we performed regressions using data on future government purchases, or with $\mathrm{CBO}$ projections of fiveyear-ahead government spending, instead of current values. Second, we adjusted the government bond variable to include only domestically held bonds. Third, we explored alternative definitions of taxes and transfers, by changing the classification of nontax payments from a revenue item to a negative transfer payment and changing the classification of federal transfers to states from a government purchase to a transfer.

92. See Flavin (1987). 
period so that the marginal utility of consumption follows a random walk. ${ }^{93}$ With a few simplifying assumptions, consumption itself follows a random walk (with drift), which implies that the change in consumption is given by

$$
\Delta C_{t}=\alpha+\varepsilon_{t},
$$

where $\varepsilon_{t}$ is a forecast error that is uncorrelated with all information in periods $t-1$ and before but may be correlated with current-period information.

Our goal is to expand on the model in equation 2 to account explicitly for Ricardian consumers and for consumers who exhibit any of a variety of types of non-Ricardian behavior. Campbell and Mankiw specify a model in which a share $\lambda$ of all disposable income $Y D$ goes to rule-of-thumb consumers who immediately consume the resources. ${ }^{94}$ The remainder of income accrues to "farsighted" consumers, who behave according to equation 2. This generates a consumption equation of the form

$$
\Delta C_{t}=\alpha+\lambda \Delta Y D_{t}+(1-\lambda) \varepsilon_{t} .
$$

Blanchard develops a model of farsighted, life-cycle consumers that also contains Ricardian equivalence as a special case (where consumers have an infinite horizon) ${ }^{95}$ Based on Blanchard, Evans, and Graham and Himarios, ${ }^{96}$ the model implies that aggregate consumption can be written as

$$
\Delta C_{t}=\alpha+\beta_{1} \Delta W_{t-1}+\beta_{2} \Delta B_{t-1}+v 1_{t},
$$

where $W$ is private net worth and $B$ is the real outstanding stock of government bonds. As Evans shows, ${ }^{97}$ life-cycle consumers will generate negative values for $\beta_{1}$ and $\beta_{2}$. In the limiting case of Ricardian equivalence, $\beta_{1}$ and $\beta_{2}$ are zero, and the equation collapses to equation 2 . Thus, if proportions $\mu_{1}$ and $\mu_{2}$ of private wealth and government bonds, respectively, are held by life-cycle consumers, and the remaining shares by Ricardian consumers, equations 3 and 4 can be combined to allow for both groups of consumers:

$$
\Delta C_{t}=\alpha+\lambda \Delta Y D_{t}+\gamma_{1} \Delta W_{t-1}+\gamma_{2} \Delta B_{t-1}+v 2_{t},
$$

where $\gamma_{i}=\beta_{i} \mu_{i}$.

93. Hall (1978).

94. Campbell and Mankiw $(1989,1990)$.

95. Blanchard (1985).

96. Blanchard (1985); Evans (1988); Graham and Himarios (1996).

97. Evans (1988). 
Finally, Ricardian consumers should not be influenced by changes in disposable income or past changes in wealth, but they may be affected by changes in expectations regarding future government purchases (although, as noted above, the sign of the effect is not clear). Moreover, for all groups, with the possible exception of strict rule-of-thumb consumers, changes in the marginal tax rates on capital and labor (MTRK and $M T R L$, respectively) may affect consumption choices. These considerations generate an Euler specification of the following form:

$$
\begin{aligned}
\Delta C_{t}= & \alpha+\lambda \Delta Y D_{t}+\gamma_{1} \Delta W_{t-1}+\gamma_{2} \Delta B_{t-1}+\varphi_{1} \Delta G S_{t} \\
& +\varphi_{2} \Delta M T R K_{t}+\varphi_{3} \Delta M T R L_{t}+u_{t},
\end{aligned}
$$

where $G S$ is again government purchases and the error term $u_{t}$ is uncorrelated with all variables in earlier time periods.

This Euler equation has a number of interesting properties. First, it allows for the presence of both rule-of-thumb consumers and life-cycle consumers, and it contains Ricardian equivalence as the special case where $\lambda=\gamma_{1}=\gamma_{2}=0 .{ }^{98}$ Thus the equation allows for testing of Ricardian equivalence in a utility-maximizing framework that nests both Ricardian and several non-Ricardian hypotheses and shows the quantitative importance of any deviations from Ricardian equivalence.

Second, with a little transformation the equation is not that different from the consumption function specification developed by Kormendi (equation 1). In the notation used earlier in the paper, disposable income can be written as $Y D=N N P-T X-R E+T R+G I N T$. When that expression is substituted into equation 6 and the coefficients on each component of disposable income are allowed to vary, the resulting equation differs from equation 1 only in that equation 1 contains a lagged NNP term and equation 6 includes marginal tax rate terms.

To isolate the effects of federal taxes on consumption, we decompose the disposable income term in equation 6 into pretax income $(Y P)$, federal taxes $(T X F)$, and state and local taxes $(T X S L)$. This yields equation 7 , which we estimate by OLS and instrumental variables in the next section:

$$
\begin{aligned}
\Delta C_{t}= & \alpha+\lambda_{1} \Delta Y P_{t}+\lambda_{2} \Delta T X F_{t}+\lambda_{3} \Delta T X S L_{t}+\gamma_{1} \Delta W_{t-1} \\
& +\gamma_{2} \Delta B_{t-1}+\varphi_{1} \Delta G S_{t}+\varphi_{2} \Delta M T R K_{t}+\varphi_{3} \Delta M T R L_{t}+u_{t} .
\end{aligned}
$$

98. These restrictions derive directly from the Campbell and Mankiw $(1989,1990)$ and Blanchard (1985) models. 


\section{Euler Equation Results}

Table 4 presents estimates of equation 7 for the period 1956-2002. ${ }^{99}$ The top panel presents the results of OLS regressions, for comparison with table 2 . The results using first differences of levels and those using first differences scaled by lagged income are somewhat smaller than those in table 2 and suggest that between 22 and 39 cents of each dollar in federal tax cuts is consumed in the year the tax cuts occur. The results using the first difference in ratios are substantially larger, suggesting that between 50 and 70 cents per dollar of tax cuts is consumed in the first year. Thus the results show no obvious bias relative to the findings in table 2.

These results, of course, still suffer from endogeneity problems. We therefore follow Campbell and Mankiw in using lagged values of the right-hand-side variables as instruments for their current value, and lagged values of consumption itself as an instrument for current income. ${ }^{100} \mathrm{In}$ models where agents are forward-looking, lagged consumption will help to predict current income but is not correlated with the stochastic component of current consumption. For reasons discussed by Robert Hall, Campbell and Mankiw, and others, ${ }^{101}$ we avoid using once-lagged variables as instruments and instead use variables that are lagged twice and three times.

The middle panel of table 4 reports instrumental variables estimates in which all of the current-period variables are treated as endogenous except for private sector wealth and government bonds, which are measured at the end of the previous period and are treated as exogenous. All of the regressions report negative effects of tax revenue on consumption. Most of the effects are statistically significant, ranging between 32 and 64 cents per dollar of tax cuts. The regressions that control for marginal tax rates usually produce larger (in absolute value) effects of tax cuts on consumption.

99. Given the lags and the choice of instruments, the availability of the tax rate variables restricts consideration to samples starting in 1956. When the tax rate variables are dropped, regressions with samples that begin earlier in the 1950s are possible. These regressions yield results very similar to those of regressions without marginal tax rates where the sample begins in 1956 .

100. Campbell and Mankiw $(1989,1990)$.

101. Hall (1988); Campbell and Mankiw (1989). 
Table 4. Euler Equation OLS and Instrumental Variables Estimates of the Effects of Taxes on Aggregate Consumption ${ }^{\mathrm{a}}$

\begin{tabular}{|c|c|c|c|c|c|c|}
\hline \multirow[b]{2}{*}{ Dependent variable } & \multicolumn{2}{|c|}{$\begin{array}{l}\text { Variables entered as first } \\
\text { differences of levels }\end{array}$} & \multicolumn{2}{|c|}{$\begin{array}{c}\text { Variables entered as first } \\
\text { differences of ratios to NNP } \\
\text { per capita }\end{array}$} & \multicolumn{2}{|c|}{$\begin{array}{l}\text { Variables entered as first } \\
\text { differences of levels, scaled } \\
\text { to NNP per capita }\end{array}$} \\
\hline & $\begin{array}{l}\text { Marginal } \\
\text { tax rate } \\
\text { excluded }\end{array}$ & $\begin{array}{l}\text { Marginal } \\
\text { tax rate } \\
\text { included }\end{array}$ & $\begin{array}{l}\text { Marginal } \\
\text { tax rate } \\
\text { excluded }\end{array}$ & $\begin{array}{l}\text { Marginal } \\
\text { tax rate } \\
\text { included }\end{array}$ & $\begin{array}{l}\text { Marginal } \\
\text { tax rate } \\
\text { excluded }\end{array}$ & $\begin{array}{l}\text { Marginal } \\
\text { tax rate } \\
\text { included }\end{array}$ \\
\hline \multicolumn{7}{|l|}{ OLS estimates } \\
\hline $\begin{array}{l}\text { Kormendi consumption } \\
\text { measure }\end{array}$ & $\begin{array}{l}-0.38 \\
(0.15)\end{array}$ & $\begin{array}{c}-0.39 \\
(0.16)\end{array}$ & $\begin{array}{c}-0.70 \\
(0.19)\end{array}$ & $\begin{array}{c}-0.56 \\
(0.14)\end{array}$ & $\begin{array}{c}-0.25 \\
(0.11)\end{array}$ & $\begin{array}{c}-0.27 \\
(0.11)\end{array}$ \\
\hline $\begin{array}{l}\text { Expenditure on nondurables } \\
\text { and services }\end{array}$ & $\begin{array}{l}-0.27 \\
(0.11)\end{array}$ & $\begin{array}{l}-0.26 \\
(0.11)\end{array}$ & $\begin{array}{l}-0.65 \\
(0.17)\end{array}$ & $\begin{array}{l}-0.50 \\
(0.13)\end{array}$ & $\begin{array}{l}-0.22 \\
(0.11)\end{array}$ & $\begin{array}{c}-0.22 \\
(0.09)\end{array}$ \\
\hline \multicolumn{7}{|c|}{$\begin{array}{l}\text { Instrumental variables, current } \\
\text { explanatory variables endogenous }\end{array}$} \\
\hline $\begin{array}{l}\text { Kormendi consumption } \\
\text { measure }\end{array}$ & $\begin{array}{c}-0.51 \\
(0.23)\end{array}$ & $\begin{array}{l}-0.64 \\
(0.20)\end{array}$ & $\begin{array}{c}-0.56 \\
(0.28)\end{array}$ & $\begin{array}{c}-0.38 \\
(0.31)\end{array}$ & $\begin{array}{l}-0.30 \\
(0.22)\end{array}$ & $\begin{array}{l}-0.45 \\
(0.18)\end{array}$ \\
\hline $\begin{array}{l}\text { Expenditure on nondurables } \\
\text { and services }\end{array}$ & $\begin{array}{c}-0.32 \\
(0.18)\end{array}$ & $\begin{array}{c}-0.41 \\
(0.16)\end{array}$ & $\begin{array}{c}-0.51 \\
(0.26)\end{array}$ & $\begin{array}{c}-0.29 \\
(0.31)\end{array}$ & $\begin{array}{c}-0.22 \\
(0.20)\end{array}$ & $\begin{array}{c}-0.32 \\
(0.16)\end{array}$ \\
\hline $\begin{array}{l}\text { Sample period } \\
\text { Instrumental variables, all ex } \\
\quad \text { variables endogenous }\end{array}$ & 1957-2002 & 1959-2002 & 1957-2002 & 1959-2002 & 1957-2002 & 1959-2002 \\
\hline $\begin{array}{l}\text { Kormendi consumption } \\
\text { measure }\end{array}$ & $\begin{array}{c}-0.62 \\
(0.40)\end{array}$ & $\begin{array}{l}-0.98 \\
(0.41)\end{array}$ & $\begin{array}{l}-0.75 \\
(0.43)\end{array}$ & $\begin{array}{c}-0.61 \\
(0.50)\end{array}$ & $\begin{array}{c}-0.44 \\
(0.35)\end{array}$ & $\begin{array}{l}-0.73 \\
(0.34)\end{array}$ \\
\hline $\begin{array}{l}\text { Expenditure on nondurables } \\
\text { and services }\end{array}$ & $\begin{array}{c}-0.42 \\
(0.35)\end{array}$ & $\begin{array}{l}-0.85 \\
(0.44)\end{array}$ & $\begin{array}{c}-0.70 \\
(0.41)\end{array}$ & $\begin{array}{c}-0.53 \\
(0.53)\end{array}$ & $\begin{array}{c}-0.51 \\
(0.39)\end{array}$ & $\begin{array}{c}-0.71 \\
(0.36)\end{array}$ \\
\hline Sample period & 1957-2002 & 1959-2002 & $1957-2002$ & 1959-2002 & 1957-2002 & 1959-2002 \\
\hline
\end{tabular}


The bottom panel of table 4 reports the effects on consumption when all right-hand-side variables, including the lagged value of private sector wealth and government bonds, are treated as endogenous. These results uniformly show a larger (in absolute value) effect of tax revenue on consumption. Six of the twelve regressions generate statistically significant effects, with coefficients ranging from 71 to 98 cents in added consumption per dollar of taxes cut. All six have p-values below .10, and in three the $\mathrm{p}$-value is below .05 . The other six regressions also show large effects (44 to 62 cents on the dollar) but are estimated less precisely.

Table 5 reports the coefficients on all regressors for the six instrumental variables regressions in table 4 that include marginal tax rates as explanatory variables. Before-tax income and federal tax revenue usually enter as important determinants of aggregate consumption. Most of the other variables do not. In particular, marginal tax rates have much smaller and less significant effects in this specification than in the consumption function specification. Government bonds have negative coefficients when they are not instrumented and positive coefficients when they are, but in neither case are the estimates statistically different from zero. Likewise, private sector wealth enters with a small, positive, but usually statistically insignificant coefficient. The state and local tax variable generally enters positively but is estimated imprecisely. The fact that standard errors are larger across the board is not unexpected in instrumental variables estimates, and they serve to highlight the generally statistically significant and economically substantial effects of federal taxes on consumption.

\section{Discussion}

The results just presented establish that changes in tax revenue can have significant negative effects on contemporaneous changes in consumption when government purchases, marginal tax rates, and other factors are controlled for. The implications of these findings for Ricardian equivalence merit additional discussion. Define a Ricardian consumer as one who would have a zero marginal propensity to consume (MPC) out of a current tax cut if all of the following assumptions hold: all taxes are lump-sum, the tax cut is coupled with a future lump-sum tax increase of equivalent present value on the consumer or the consumer's heirs; the future income of the consumer and his or her heirs is known; and government purchases are unaffected. 
Table 5. Instrumental Variables Coefficient Estimates for All Independent Variables in the Euler Equation ${ }^{\mathrm{a}}$

\begin{tabular}{|c|c|c|c|c|c|c|}
\hline \multirow[b]{2}{*}{ Independent variable } & \multicolumn{2}{|c|}{$\begin{array}{l}\text { Variables entered as first } \\
\text { differences of levels }\end{array}$} & \multicolumn{2}{|c|}{$\begin{array}{c}\text { Variables entered as first } \\
\text { differences of ratios to NNP } \\
\text { per capita }\end{array}$} & \multicolumn{2}{|c|}{$\begin{array}{l}\text { Variables entered as first } \\
\text { differences of levels, scaled } \\
\text { to NNP per capita }\end{array}$} \\
\hline & $\begin{array}{l}\text { Kormendi } \\
\text { consumption } \\
\text { measure }\end{array}$ & $\begin{array}{l}\text { Nondurables } \\
\text { and services } \\
\text { expenditure }\end{array}$ & $\begin{array}{l}\text { Kormendi } \\
\text { consumption } \\
\text { measure }\end{array}$ & $\begin{array}{l}\text { Nondurables } \\
\text { and services } \\
\text { expenditure }\end{array}$ & $\begin{array}{l}\text { Kormendi } \\
\text { consumption } \\
\text { measure }\end{array}$ & $\begin{array}{c}\text { Nondurables } \\
\text { and services } \\
\text { expenditure }\end{array}$ \\
\hline \multicolumn{7}{|c|}{ Current independent variables endogenous } \\
\hline Before-tax income & $\begin{array}{c}0.41 \\
(0.17)\end{array}$ & $\begin{array}{c}0.36 \\
(0.14)\end{array}$ & $\begin{array}{c}0.94 \\
(0.27)\end{array}$ & $\begin{array}{c}0.89 \\
(0.25)\end{array}$ & $\begin{array}{c}0.41 \\
(0.13)\end{array}$ & $\begin{array}{c}0.41 \\
(0.13)\end{array}$ \\
\hline Government purchases & $\begin{array}{c}0.25 \\
(0.29)\end{array}$ & $\begin{array}{c}0.20 \\
(0.24)\end{array}$ & $\begin{array}{c}0.11 \\
(0.27)\end{array}$ & $\begin{array}{c}0.04 \\
(0.28)\end{array}$ & $\begin{array}{c}0.12 \\
(0.20)\end{array}$ & $\begin{array}{c}0.11 \\
(0.19)\end{array}$ \\
\hline Federal taxes & $\begin{array}{c}-0.64 \\
(0.20)\end{array}$ & $\begin{array}{c}-0.41 \\
(0.16)\end{array}$ & $\begin{array}{c}-0.38 \\
(0.31)\end{array}$ & $\begin{array}{l}-0.29 \\
(0.31)\end{array}$ & $\begin{array}{l}-0.45 \\
(0.18)\end{array}$ & $\begin{array}{l}-0.32 \\
(0.16)\end{array}$ \\
\hline State and local taxes & $\begin{array}{c}0.22 \\
(0.80)\end{array}$ & $\begin{array}{c}0.74 \\
(0.66)\end{array}$ & $\begin{array}{l}-0.16 \\
(0.85)\end{array}$ & $\begin{array}{c}0.09 \\
(0.87)\end{array}$ & $\begin{array}{c}0.48 \\
(0.54)\end{array}$ & $\begin{array}{c}0.83 \\
(0.52)\end{array}$ \\
\hline Lagged government debt & $\begin{array}{c}-0.02 \\
(0.03)\end{array}$ & $\begin{array}{c}-0.02 \\
(0.02)\end{array}$ & $\begin{array}{c}-0.01 \\
(0.04)\end{array}$ & $\begin{array}{c}-0.01 \\
(0.04)\end{array}$ & $\begin{array}{l}-0.01 \\
(0.02)\end{array}$ & $\begin{array}{l}-0.01 \\
(0.02)\end{array}$ \\
\hline Lagged wealth & $\begin{array}{c}0.03 \\
(0.01)\end{array}$ & $\begin{array}{c}0.01 \\
(0.01)\end{array}$ & $\begin{array}{c}0.00 \\
(0.01)\end{array}$ & $\begin{array}{c}0.00 \\
(0.01)\end{array}$ & $\begin{array}{c}0.01 \\
(0.01)\end{array}$ & $\begin{array}{c}0.01 \\
(0.01)\end{array}$ \\
\hline Marginal tax rate on capital ${ }^{\mathrm{b}}$ & $\begin{array}{c}2.60 \\
(1.60)\end{array}$ & $\begin{array}{c}1.50 \\
(1.30)\end{array}$ & $\begin{array}{c}0.00 \\
(0.10)\end{array}$ & $\begin{array}{c}-0.10 \\
(0.10)\end{array}$ & $\begin{array}{c}0.10 \\
(0.10)\end{array}$ & $\begin{array}{c}0.10 \\
(0.10)\end{array}$ \\
\hline Marginal tax rate on labor ${ }^{b}$ & $\begin{array}{c}-0.70 \\
(1.40)\end{array}$ & $\begin{array}{c}-0.90 \\
(1.10)\end{array}$ & $\begin{array}{c}0.00 \\
(0.10)\end{array}$ & $\begin{array}{c}-0.10 \\
(0.10)\end{array}$ & $\begin{array}{c}0.00 \\
(0.10)\end{array}$ & $\begin{array}{c}0.00 \\
(0.00)\end{array}$ \\
\hline Constant & $\begin{array}{c}0.16 \\
(0.06)\end{array}$ & $\begin{array}{c}0.12 \\
(0.05)\end{array}$ & $\begin{array}{c}0.00 \\
(0.00)\end{array}$ & $\begin{array}{c}0.00 \\
(0.00)\end{array}$ & $\begin{array}{c}0.01 \\
(0.00)\end{array}$ & $\begin{array}{c}0.01 \\
(0.00) \\
(\text { continued })\end{array}$ \\
\hline
\end{tabular}


Table 5. Instrumental Variables Coefficient Estimates for All Independent Variables in the Euler Equationa (continued)

\begin{tabular}{|c|c|c|c|c|c|c|}
\hline \multirow[b]{2}{*}{ Independent variable } & \multicolumn{2}{|c|}{$\begin{array}{l}\text { Variables entered as first } \\
\text { differences of levels }\end{array}$} & \multicolumn{2}{|c|}{$\begin{array}{c}\text { Variables entered as first } \\
\text { differences of ratios to NNP } \\
\text { per capita }\end{array}$} & \multicolumn{2}{|c|}{$\begin{array}{c}\text { Variables entered as first } \\
\text { differences of levels, scaled } \\
\text { to NNP per capita }\end{array}$} \\
\hline & $\begin{array}{l}\text { Kormendi } \\
\text { consumption } \\
\text { measure }\end{array}$ & $\begin{array}{c}\text { Nondurables } \\
\text { and services } \\
\text { expenditure }\end{array}$ & $\begin{array}{c}\text { Kormendi } \\
\text { consumption } \\
\text { measure }\end{array}$ & $\begin{array}{c}\text { Nondurables } \\
\text { and services } \\
\text { expenditure }\end{array}$ & $\begin{array}{l}\text { Kormendi } \\
\text { consumption } \\
\text { measure }\end{array}$ & $\begin{array}{c}\text { Nondurables } \\
\text { and services } \\
\text { expenditure }\end{array}$ \\
\hline \multicolumn{7}{|c|}{ All explanatory variables endogenous } \\
\hline Before-tax income & $\begin{array}{c}0.52 \\
(0.26)\end{array}$ & $\begin{array}{c}0.49 \\
(0.27)\end{array}$ & $\begin{array}{c}0.89 \\
(0.29)\end{array}$ & $\begin{array}{c}0.84 \\
(0.28)\end{array}$ & $\begin{array}{c}0.48 \\
(0.18)\end{array}$ & $\begin{array}{c}0.51 \\
(0.20)\end{array}$ \\
\hline Government purchases & $\begin{array}{c}0.16 \\
(0.40)\end{array}$ & $\begin{array}{c}0.09 \\
(0.40)\end{array}$ & $\begin{array}{c}0.12 \\
(0.31)\end{array}$ & $\begin{array}{c}0.07 \\
(0.33)\end{array}$ & $\begin{array}{c}0.09 \\
(0.25)\end{array}$ & $\begin{array}{c}0.07 \\
(0.28)\end{array}$ \\
\hline Federal taxes & $\begin{array}{r}-0.98 \\
(0.41)\end{array}$ & $\begin{array}{l}-0.85 \\
(0.44)\end{array}$ & $\begin{array}{c}-0.61 \\
(0.50)\end{array}$ & $\begin{array}{r}-0.53 \\
(0.53)\end{array}$ & $\begin{array}{l}-0.73 \\
(0.34)\end{array}$ & $\begin{array}{c}-0.71 \\
(0.36)\end{array}$ \\
\hline State and local taxes & $\begin{array}{c}0.36 \\
(1.04)\end{array}$ & $\begin{array}{c}0.65 \\
(1.06)\end{array}$ & $\begin{array}{c}0.09 \\
(0.98)\end{array}$ & $\begin{array}{c}0.34 \\
(1.00)\end{array}$ & $\begin{array}{c}0.47 \\
(0.69)\end{array}$ & $\begin{array}{c}0.76 \\
(0.76)\end{array}$ \\
\hline Lagged government debt & $\begin{array}{c}0.04 \\
(0.11)\end{array}$ & $\begin{array}{c}0.09 \\
(0.11)\end{array}$ & $\begin{array}{c}0.05 \\
(0.11)\end{array}$ & $\begin{array}{c}0.07 \\
(0.11)\end{array}$ & $\begin{array}{c}0.02 \\
(0.08)\end{array}$ & $\begin{array}{c}0.04 \\
(0.08)\end{array}$ \\
\hline Lagged wealth & $\begin{array}{c}0.04 \\
(0.02)\end{array}$ & $\begin{array}{c}0.03 \\
(0.02)\end{array}$ & $\begin{array}{c}0.01 \\
(0.03)\end{array}$ & $\begin{array}{c}0.01 \\
(0.03)\end{array}$ & $\begin{array}{c}0.03 \\
(0.02)\end{array}$ & $\begin{array}{c}0.03 \\
(0.02)\end{array}$ \\
\hline Marginal tax rate on capital ${ }^{b}$ & $\begin{array}{c}2.50 \\
(2.30)\end{array}$ & $\begin{array}{c}1.30 \\
(2.30)\end{array}$ & $\begin{array}{c}0.00 \\
(0.10)\end{array}$ & $\begin{array}{c}-0.10 \\
(0.10)\end{array}$ & $\begin{array}{c}0.10 \\
(0.10)\end{array}$ & $\begin{array}{c}0.10 \\
(0.10)\end{array}$ \\
\hline Marginal tax rate on labor ${ }^{b}$ & $\begin{array}{c}0.60 \\
(2.30)\end{array}$ & $\begin{array}{c}0.80 \\
(2.30)\end{array}$ & $\begin{array}{c}0.00 \\
(0.10)\end{array}$ & $\begin{array}{c}0.00 \\
(0.10)\end{array}$ & $\begin{array}{c}0.00 \\
(0.10)\end{array}$ & $\begin{array}{c}0.00 \\
(0.10)\end{array}$ \\
\hline Constant & $\begin{array}{c}0.11 \\
(0.10)\end{array}$ & $\begin{array}{c}0.07 \\
(0.10)\end{array}$ & $\begin{array}{c}0.00 \\
(0.00)\end{array}$ & $\begin{array}{c}0.00 \\
(0.00)\end{array}$ & $\begin{array}{c}0.01 \\
(0.00)\end{array}$ & $\begin{array}{c}0.00 \\
(0.00)\end{array}$ \\
\hline
\end{tabular}

Source: Authors' regressions using data from Bureau of Economic Analysis, National Income and Product Accounts; Gravelle (2004); Department of the Treasury; Federal Reserve; U.S. Census Bureau; and Standard and Poor's.

a. Table reports regression coefficients for all independent variables in the regressions including the marginal tax rate in the bottom two panels of table 4 . Numbers in parentheses are robust standard errors. Number of observations $N=44$. All lags are one-period lags. Consumption measures are as defined in table 2.

b. Both the coefficient and the standard error are multiplied by 100 . 
It is well established that a Ricardian consumer can have a nonzero MPC out of a tax cut if any of these assumptions is violated. As a result, interpreting our empirical results requires some care. We make two broad points. First, violations of several of the assumptions above can generate nonzero MPCs for Ricardian consumers but seem unlikely to explain our empirical results, which generate MPCs between 50 and 80 percent. Second, the violations that can explain such high MPCs out of tax cuts also generate strongly non-Ricardian effects of public policies even if consumers are Ricardian in the sense defined above.

On the first point: violations of several of the assumptions may indeed exist in the real world but are unlikely to explain our results. If taxes are distortionary, tax cuts will alter relative prices and hence affect consumption and labor supply through standard substitution effects. However, the marginal propensity to consume out of a temporary tax cut created by distortionary taxes is likely to be either small or negative for Ricardian consumers. ${ }^{102}$

Likewise, the "fiscal rule" that households believe to be operating will affect the MPC, but it is unlikely that uncertainty about fiscal rules can explain our results. If the path of government purchases is held constant and future income is known, but the incidence of the future lump-sum tax is uncertain (in terms of either the timing or who will be affected), a lumpsum tax cut now coupled with a lump-sum tax increase later could lead Ricardian consumers to increase their precautionary saving. That is, they would save not only the tax cut but also an additional amount to account for the increased riskiness of future taxes. This would generate a negative MPC out of the tax cut. ${ }^{103}$ Clearly, this cannot explain the MPCs estimated above.

The more likely it is that a tax cut will be financed by reductions in future government purchases, the more likely that the MPC out of a tax cut will be positive for Ricardian consumers, because such a tax cut would imply that the burden of future taxes would also fall-that is, that the tax cut would be permanent. But current tax revenue does not appear to be a

102. Cardia (1997) shows that, in simulation models that would generate Ricardian equivalence but for the presence of distortionary taxes, or distortionary taxes in combination with finite horizons, the estimated MPC out of a tax cut in equations like those estimated in this paper is less than .08. Judd (1987b) shows that, in an infinite-horizon model, the MPC out of a temporary cut in tax rates, coupled with a future increase in tax rates, is negative.

103. Barro (1989); Kormendi (1983); Seater (1993). 
good predictor of future government purchases, and so it is unlikely that changing views of government purchases explain our results. ${ }^{104}$

On the second point: simulation models suggest that, if future income is uncertain or if taxes serve a social insurance role in reducing the amplitude of swings in uncertain future income, the MPC out of a tax cut could be within the 50 to 80 percent range that we estimate. ${ }^{105}$ In this case consumers are "Ricardian" in the sense defined above, but intergenerational transfers of public resources have long-lasting, strongly non-Ricardian effects on the economy.

A related issue is that our empirical consumption results address only short-term Ricardian equivalence. In some models Ricardian equivalence fails in the short run but holds in the long run. ${ }^{106}$ In others, small deviations from short-term Ricardian equivalence grow over time into very large deviations from long-term Ricardian equivalence. ${ }^{107}$

Thus our empirical findings cannot distinguish between the view that consumers are truly non-Ricardian and the view that consumers are Ricardian but that the characteristics of enacted policies do not conform to the assumptions stated above under which Ricardian equivalence holds. In either case, however, our results imply that, controlling for other factors, tax cut-induced deficits reduce national saving, at least in the short run. This is the sense in which we describe our results as "non-Ricardian."

\section{Summary}

Our consumption function OLS regressions demonstrate robust nonRicardian effects even within the basic specification that has previously suggested the strongest support for Ricardian equivalence. When the sample period is extended to cover the most recent years, federal and state tax variables are split, and a marginal tax rate variable is included, the results suggest that about 30 to 46 cents of every dollar in tax cuts is spent in the same year-and the effect is precisely estimated in all specifications that use the full sample period.

The OLS regressions likely suffer from severe simultaneity problems, however. When instrumental variables regressions are used in the Euler

104. Modigliani and Sterling (1986) and Feldstein and Elmendorf (1990) report regressions of current government purchases on lagged values of tax revenue, controlling for other factors, and find no predictive power of tax revenue for future purchases.

105. Barsky, Mankiw, and Zeldes (1986); Feldstein (1988).

106. Smetters (1999); Mankiw (2000b).

107. Auerbach and Kotlikoff (1987). 
specification, with twice- and three-times-lagged variables as instruments, the results are generally more strongly non-Ricardian. If we drop the highest and lowest estimates in the bottom panel of table 4, the remaining coefficients from this specification, which is our preferred one, suggest that about 50 to 85 cents of every dollar in tax cuts is spent in the first year; half of the effects are measured precisely. This range is consistent with some previous assessments, ${ }^{108}$ but it is inconsistent with the Ricardian prediction of a full offset from private saving, and the difference, as we will discuss further in the concluding section, is economically important.

\section{Deficits and Interest Rates}

In this section we present our findings on the effects of deficits and other fiscal measures on long-term interest rates. We begin by reviewing previous research on this issue.

\section{Previous Research}

For a number of well-known reasons, the effects of fiscal policy on interest rates have proved difficult to pin down statistically. The issues include the appropriate definitions of deficits and debt, whether deficits or debt should be the variable of interest, how to distinguish expected from unexpected changes in these variables, and the potential endogeneity of many of the key explanatory variables. We discuss several of these issues below. ${ }^{109}$ In part because of these statistical issues, the evidence from the empirical literature as a whole is mixed. ${ }^{110}$

108. For example, Bernheim (1987) and the CBO ("Description of Economic Models," November 1998) conclude that private saving would rise by between 20 and 50 percent of an increase in the deficit (hence consumption would rise by between 50 and 80 percent of the increase in the deficit). Elmendorf and Liebman (2000) conclude that private saving would offset 25 percent of the increase in the deficit. Gale and Potter (2002) estimate that private saving will offset 31 percent of the decline in public saving caused by the 2001 tax cut.

109. Bernheim (1987), Elmendorf and Mankiw (1999), and Seater (1993) provide comprehensive analyses.

110. Previous analyses reach widely varying conclusions about the effects of deficits on interest rates. For example, Barth and others (1991) survey forty-two studies through 1989, seventeen of which found a "predominately significant, positive" effect of deficits on interest rates (that is, larger deficits raised interest rates); six studies found mixed effects, and 
As we noted in our discussion of the stylized models above, we take no a priori view regarding whether interest rates should be affected by deficits or by debt. Below, however, we often refer to the relationship between interest rates and "deficits," in part for simplicity and in part because our results suggest that deficits contain more useful information than debt in explaining interest rates.

PROJECTED DEFICITS AND INTEREST RATES. Our previous contribution to interpreting the literature has been to highlight the key role of using expected deficits rather than current deficits. ${ }^{111}$ Almost twenty years ago, Feldstein wrote, "it is wrong to relate the rate of interest to the concurrent budget deficit without taking into account the anticipated future deficits. It is significant that almost none of the past empirical analyses of the effect of deficits on interest rates makes any attempt to include a measure of expected future deficits." 12 Since financial markets are forward-looking, excluding expectations could bias the analysis toward finding no relationship between interest rates and deficits. ${ }^{113}$

Over the past twenty years, many studies have incorporated more accurate information on expectations of future sustained deficits. These studies tend to find economically and statistically significant connections between anticipated deficits and current interest rates. In a recent paper we summarize the findings of the studies on this topic reviewed by James Barth and others as well as

nineteen found "predominately insignificant or negative" effects. Barth and others (p. 72) conclude that "Since the available evidence on the effects of deficits is mixed, one cannot say with complete confidence that budget deficits raise interest rates. . . . But, equally important, one cannot say that they do not have these effects." Other reviewers of the literature have reached similar conclusions. Elmendorf and Mankiw (1999, p. 1658) note that "Our view is that this literature . . is not very informative." Bernheim $(1989$, p. 56$)$ writes that "it is easy to cite a large number of studies that support any conceivable position." Appendix table A-1 updates the Barth and others (1991) survey and shows that, of more than sixty studies, roughly half found a predominantly significant, positive effect and the other half found either no effect or mixed effects.

111. Gale and Orszag $(2002,2003 a)$. One recent study expands the literature along a different dimension: Kiley (2003) examines the relationship between current government debt and the return to capital in the nonfinancial corporate sector. Kiley finds that a 1-percentagepoint increase in the debt-GDP ratio is associated with a 10-basis-point increase in the return to capital.

112. Feldstein (1986).

113. Bernheim (1987) notes that, if households perfectly anticipate future deficits, one may well find no empirical relationship between current deficits and interest rates, even though the path of interest rates and economic activity would be substantially different in the absence of the deficits. 
several more recent papers. ${ }^{114}$ Appendix table A-1 shows that, of nineteen papers that incorporate timely information on projected deficits, thirteen find predominantly positive, significant effects between anticipated deficits and current interest rates, five find mixed effects, and only one finds no effects. The studies that find no significant effect are disproportionately those that do not take expectations into account at all or do so only indirectly through a vector autoregression. Thus, although the literature as a whole, taken at face value, generates mixed results, those analyses that focus on the effects of anticipated deficits tend to find a positive and significant impact on interest rates.

The challenge in incorporating market expectations about future deficits is that such expectations are not directly observable. An important caveat to the literature examining expected deficits, then, is that, to the extent that proxies for expected deficits are imperfect reflections of current expectations, the coefficient on the projected deficit will tend to be biased toward zero because of classical measurement error, and the tendency will be to underestimate the effects of deficits on interest rates.

Researchers have used different strategies in the face of this challenge. One approach is to use published forecasts of the deficit as a proxy for market expectations. For example, Elmendorf, using deficit forecasts from Data Resources, Inc., finds that an increase in the projected deficit of 1 percent of GNP raises five-year bond yields by 43 basis points. Matthew Canzoneri, Robert Cumby, and Behzad Diba, using CBO projections, find that "an increase in projected future deficits averaging 1 percent of current GDP is associated with an increase in the long-term interest rate relative to the short-term interest rate of 53 to 60 basis points." 115

One potential concern with these studies is that the business cycle could be affecting current yields. ${ }^{116}$ Thomas Laubach suggests a novel way to resolve this issue: ${ }^{117}$ he examines the relationship between projected deficits (or debt) and the level of real forward (five-year-ahead)

114. Gale and Orszag (2003a); Barth and others (1991).

115. Canzoneri, Cumby, and Diba (2002, p. 365).

116. For example, in a recession the projected unified deficit could increase merely because of the lingering effects from the rise in debt during the downturn; at the same time, the yield curve could steepen as short-term interest rates are depressed by Federal Reserve policy. This could potentially introduce an artificial relationship, actually driven by the business cycle and monetary policy, between the yield spread and the projected unified deficit.

117. Laubach (2003). 
long-term interest rates. The underlying notion is that current business cycle conditions should not influence the long-term rates expected to prevail beginning five years from now. Laubach uses $\mathrm{CBO}$ and Office of Management and Budget (OMB) deficit and debt projections and finds that a 1-percentage-point increase in the five-year-ahead projected deficitGDP ratio raises the five-year-ahead interest rate on ten-year Treasury notes by between 24 and 39 basis points, and that a 1-percentage-point increase in the projected debt-GDP ratio raises the same long-term forward rate by between 3.5 and 5.6 basis points.

Following Laubach but controlling for additional variables, Engen and Hubbard use CBO projections and obtain somewhat smaller effects. ${ }^{118}$ They find that an increase in the projected deficit equal to 1 percent of GDP raises the five-year-ahead ten-year rate (the same rate Laubach examines) by 18 basis points, and that an increase in the projected debt equal to 1 percent of GDP raises the forward long-term rate by between 2.8 and 3.3 basis points.

For Laubach and for Engen and Hubbard, the deficit-based results are not dissimilar from the debt-based results. Consider, for example, an increase in the budget deficit equal to 1 percent of GDP in each year over the next ten years. By the end of the ten years, such an increase will have raised government debt by roughly 10 percent of GDP. The deficit-based results found by Laubach would suggest about a 30-basis-point increase in interest rates in this scenario, whereas the debt-based results would suggest about a 45-basis-point increase. Likewise, the deficit-based results of Engen and Hubbard would suggest an increase in long-term rates of roughly 20 basis points, and their debt-based results suggest an increase of roughly 30 basis points (ten times the effect for an increase of 1 percent of GDP).

A second approach to incorporating expected deficits involves event analysis of news reports about deficit reduction legislation or budget projections. This approach examines the change in interest rates (or other variables) on the day on which deficit news is released. For example, Elmendorf examines financial market reactions to events surrounding passage of the Gramm-Rudman-Hollings legislation in 1985 and the Budget Enforcement Act of $1990 ;{ }^{119}$ he concludes that "higher expected government spending and budget deficits raised real interest rates ... while lower expected spend-

118. Engen and Hubbard (2004).

119. Elmendorf (1996). 
ing and deficits reduced real rates." ${ }^{120}$ Unfortunately, given the inability to measure market expectations, this approach does not permit a mapping between the size of the unanticipated deficit and the interest rate effect. ${ }^{121}$

Notably, the results of most studies using either of the two approaches to incorporating anticipated deficits are consistent with the range of 20 to 60 basis points for an increase in projected deficits equal to 1 percent of GDP over ten years mentioned by us in a previous paper, and with the range of 30 to 60 basis points proposed by Robert Rubin, Orszag, and Allen Sinai. ${ }^{122}$ This range is also consistent with the results of large macroeconometric models. ${ }^{123}$ The simplified Solow model and debt calculation discussed

120. The Council of Economic Advisers (Economic Report of the President, 1994, p. 78), studying the events surrounding passage of the Omnibus Budget Reconciliation Act of 1993, concluded that event analysis "linking the announcement and enactment of credible budget reduction to changes in the long-term interest rate ... provides support for the view that the interest rate declines were largely due to budget policy."

121. Several other papers examine interest rate changes surrounding the release of new budget projections. Thorbecke (1993) uses OMB and CBO projections and finds that a $\$ 100$ billion increase in the deficit (relative to the previously projected level) is associated with an immediate increase in ten-year interest rates of 14 to 26 basis points. Quigley and Porter-Hudak (1994) use CBO and OMB projections and find that a 1 percent increase in the deficit itself (not as a percentage of GDP) raises short-term interest rates by 0.37 to 0.87 basis point. Assuming a baseline deficit of 2 percent of GDP, their result implies that an increase in the deficit of 1 percent of GDP (a 50 percent increase in the deficit) would raise short-term interest rates by 18.5 to 43.5 basis points. Kitchen (1996) uses changes in $\mathrm{OMB}$ forecasts and finds a statistically significant but quite modest effect: an increase in the deficit projection of 1 percent of GDP raises ten-year bond yields by 3.4 basis points for one-year budget projections. He finds even smaller effects for multiyear budget projections on long-term interest rates. Calomiris and others (2004) examine announcement effects about previous deficits, rather than announcement effects about future deficits or future legislation. They find no effects on current interest rates of the announcement of the previous month's deficit. Their deficit measure, however, is based on the monthly budget updates provided by the $\mathrm{CBO}$ and the Department of the Treasury. These monthly updates are quite noisy and depend on factors such as the timing of defense contract payments. The variation in the monthly data is thus unlikely to provide significant information about the budget outlook.

122. Gale and Orszag (2003a); Rubin, Orszag, and Sinai (2004). Brook (2003) similarly concludes that "most empirical work conducted in the past ten years estimates the impact on US real long-term interest rates of a sustained 1 percentage point decrease in the US fiscal position to be in the range of 20-40 basis points, and the impact on the slope of the yield curve to be in the range of $10-60$ basis points."

123. Almost all major macroeconometric models imply an economically significant connection between changes in budget deficits and changes in long-term interest rates. The precise effects depend on a wide variety of factors, including whether the change in the deficit is caused by a change in taxes or a change in spending, how monetary policy reacts, 
above generate somewhat larger numbers, but those calculations assume a closed economy. In a large open economy like the United States, the effect of deficits on interest rates would be expected to be somewhat smaller, and this is consistent with the empirical evidence summarized above.

VECTOR AUTOREGRESSIONS. Some of the most frequently cited papers that find no effect of deficits on interest rates, including those by Evans and by Charles Plosser, employ vector autoregressions (VARs). ${ }^{124}$ The VARs in these studies are typically based on a very limited number of variables and only on past values of such variables; they ignore information on current and projected deficits that is not reflected in such variables but may be widely known to market participants. As a result, the VARbased projections have been shown to be inferior to those produced by the OMB or Data Resources, Inc. ${ }^{125}$ The implication is that VAR-based projections based on past values of variables are more likely to suffer from measurement error and thus to be biased toward showing no effect of deficits on interest rates. ${ }^{126}$

Despite these limitations, several recent papers have applied the VAR methodology to examining the connection between deficits and interest rates. For example, Canzoneri, Cumby, and Diba include both the federal funds rate and the ten-year bond rate in a structural VAR; they find that the ten-year yield rises by 45 basis points immediately, and by roughly 40 basis points in the long run, in response to an upward spending shock equal to 1 percent of GDP. ${ }^{127}$ Engen and Hubbard use a VAR framework that includes anticipated deficits to estimate that an increase in the federal deficit equal to 1 percent of GDP causes the real interest rate to rise by 12 basis

and how foreign governments react. The results vary widely, in part because different policies are simulated and standardization is difficult, but suggest that a sustained increase in the primary (noninterest) deficit of 1 percent of GDP would raise interest rates by 40 to 50 basis points after one year and 50 to 100 basis points after ten years (see Gale and Orszag, 2002).

124. Evans (1987a, 1987b); Plosser (1982, 1987a).

125. Bernheim (1987); Cohen and Garnier (1991); Elmendorf (1993).

126. These studies have also been criticized on other grounds. For example, the tests appear to have very little power and in some cases are even unable to reject the hypothesis that expected inflation has no effect on nominal interest rates, and the results are not robust to changes in sample period or specification. For further discussion see Bernheim (1987) and Elmendorf and Mankiw (1999). A recent study by Kormendi and Protopapadakis (2004) shares the characteristic of estimating the effects on interest rates of a deficit measure that depends only on past values of the explanatory variables.

127. Canzoneri, Cumby, and Diba (2002). 
points. ${ }^{128}$ Qiang Dai and Thomas Philippon estimate a structural VAR that uses information provided by no-arbitrage restrictions on the yield curve. ${ }^{129}$ They conclude that a 1-percent-of-GDP increase in the unified deficit raises ten-year bond yields by 41 basis points. Silvia Ardagna, Francesco Caselli, and Timothy Lane, using data from a panel of sixteen advanced industrial countries over several decades, show in a VAR that a 1-percent-of-GDP increase in the primary deficit leads to a cumulative increase in interest rates of almost 150 basis points over ten years. ${ }^{130}$ They also show that the initial, static effect of such an increase is in the neighborhood of 10 basis points.

\section{Specification}

To examine these issues we follow Laubach and Engen and Hubbard and undertake reduced-form regressions of the following generic form: ${ }^{131}$

$$
i_{t}=\alpha+\beta f_{t}+\Gamma \mathbf{Z}+\varepsilon_{t},
$$

where $i$ is a measure of the interest rate, $f$ is a measure of fiscal policy, and $\mathbf{Z}$ is a vector of control variables. ${ }^{132}$

Our primary interest is in the coefficient $\beta$, which estimates the effect of the fiscal policy variable on interest rates. We examine the role of several such variables, each expressed as a share of GDP, at different time periods: federal publicly held debt, the unified deficit, the primary deficit, and primary outlays and revenue.

Since it is conceivable that both stock and flow measures of fiscal policy matter, and that the effect of a change in one fiscal variable could depend on the level of the other, we include both debt and deficits in some of the regressions. ${ }^{133}$ The regressions that separate primary outlays and revenue provide insight to the extent that, as noted in the discussion of Ricardian equiva-

128. Engen and Hubbard (2004).

129. Dai and Phillippon (2004).

130. Ardagna, Caselli, and Lane (2004).

131. Laubach (2003); Engen and Hubbard (2004).

132. Details of the variable definitions and sources used in these regressions may be found at www.brookings.edu/es/commentary/journals/bpea-macro/2004_2_bpea_interest data.pdf or obtained from the authors on request.

133. Ardagna, Caselli, and Lane (2004, p. 4) include both debt and deficits in their model, for similar reasons: “. . . in theory, the relationship between fiscal policy and interest rates may be mediated by either variable. ... Furthermore, even if one were specifically interested in the effects of only one of these variables, it would still make sense to control for the other. For example, given the current stock of debt, including the deficit may help [control] for the expected future path of the debt itself." 
lence above, changes in outlays could have different effects on national saving and thus on interest rates than changes in revenue. ${ }^{134} \mathrm{We}$ undertake several different versions of our generic regression, all of them using data from 1976 to 2004:

-Effects of projected fiscal policy on forward interest rates. Our preferred specifications examine the relationship between forward long-term interest rates and projected fiscal variables. This specification comes closest to eliminating the confounding effect of current macroeconomic conditions on both interest rates and deficits: most projections assume that the economy will be operating at full employment within a relatively short projection period into the future. In these specifications, $i_{t}$ reflects the simple average of one-year-forward interest rates from five to fourteen years ahead, calculated from the yield curve for zero-coupon bonds. ${ }^{135}$ This provides a forward ten-year interest rate. The fiscal policy measures $f_{t}$ are measured five years ahead, as a share of projected GDP in that year, and are taken from the $\mathrm{CBO}$ baseline projections.

-Effects of projected fiscal policy on current interest rates. In these regressions, $i_{t}$ is the current ten-year constant-maturity Treasury yield rather than the forward yield. The fiscal measures are the same as above.

-Effects of current fiscal policy on current interest rates. In these regressions we examine the relationship between current long-term rates and current rather than projected fiscal policy outcomes. The fiscal measures are all for the current year.

We perform (but do not always report) each regression using both real and nominal values of the variables. We compute the real interest rate by adjusting the nominal rate for the long-term inflationary expectations series incorporated in the Federal Reserve Board's FRB/US macroeconomic model. ${ }^{136}$ In the regressions explaining the nominal interest rate, the inflationary expectations series is included as an explanatory variable. In

134. Ricardian equivalence is a statement about the effects of variations in the timing of lump-sum tax payments, holding constant both the path of transfers and government purchases. Our regressions separate tax revenue from purchases and transfers.

135. These variables and some of the other data used in this study come from Thomas Laubach and Eric Engen. The forward interest rate is computed from the zero-coupon yield curve as of the last trading day for the month of the CBO projection.

136. Since 1991:3, this series is based on that of the Survey of Professional Forecasters published by the Federal Reserve Bank of Philadelphia. An appendix to Laubach (2003) describes this series before 1991:3. 
both cases the variable measures expected inflation over the subsequent twelve-month period.

All regressions include a constant term and an estimate of the GDP growth rate. The equations using projected fiscal policy include the growth rate projected by the $\mathrm{CBO}$ five years ahead. The equations using current fiscal policy measures include the current growth rate.

We include several additional control variables, since macroeconomic conditions can affect the level of interest rates associated with any given fiscal policy outcome. We include a dummy variable for periods when the economy is in recession (as determined by the Business Cycle Dating Committee of the National Bureau of Economic Research); the variable is both entered on its own and interacted with the fiscal measures. The purpose of this dummy and interaction term is to examine whether, even when controlling for projected GDP growth, future fiscal policy outcomes have a different effect on interest rates during a recession than during a recovery. ${ }^{137}$

Following Laubach and Engen and Hubbard, ${ }^{138}$ we include a measure of the equity premium, which is intended to control for changes in risk aversion, which in turn could affect interest rates. The measure is defined as dividend income, from the National Income and Product Accounts, divided by the market value of corporate equities held by households, from the Federal Reserve's Flow of Funds accounts, plus the trend growth rate in real GDP, minus the real yield on ten-year Treasury notes. ${ }^{139}$ We follow Engen and Hubbard in controlling for Federal Reserve holdings (in the debt equations) and purchases (in the deficit equations) of Treasury securities as a share of GDP, as a way of controlling for monetary policy. ${ }^{140} \mathrm{We}$ also follow Engen and Hubbard in including an oil price variable. ${ }^{141}$

Finally, Engen and Hubbard include a dummy variable for changes in defense spending, defined as the defense dummy variable constructed by

137. Rubin, Orszag, and Sinai (2004) raised such a possibility.

138. Laubach (2003); Engen and Hubbard (2004).

139. Laubach (2003).

140. The results were not affected by substituting the federal funds rate or the threemonth Treasury rate for Federal Reserve purchases or holdings of Treasury securities.

141. Engen and Hubbard (2004) cite evidence in Barro and Sala-i-Martin (1991) and Barro (1991) that real oil prices can affect real interest rates. We include the spot price for West Texas Intermediate crude oil, adjusted by the GDP deflator. This oil price series is slightly different from that in Engen and Hubbard (2004). The empirical results are unaffected by this difference. 
Figure 10. Defense Spending, 1976-2003

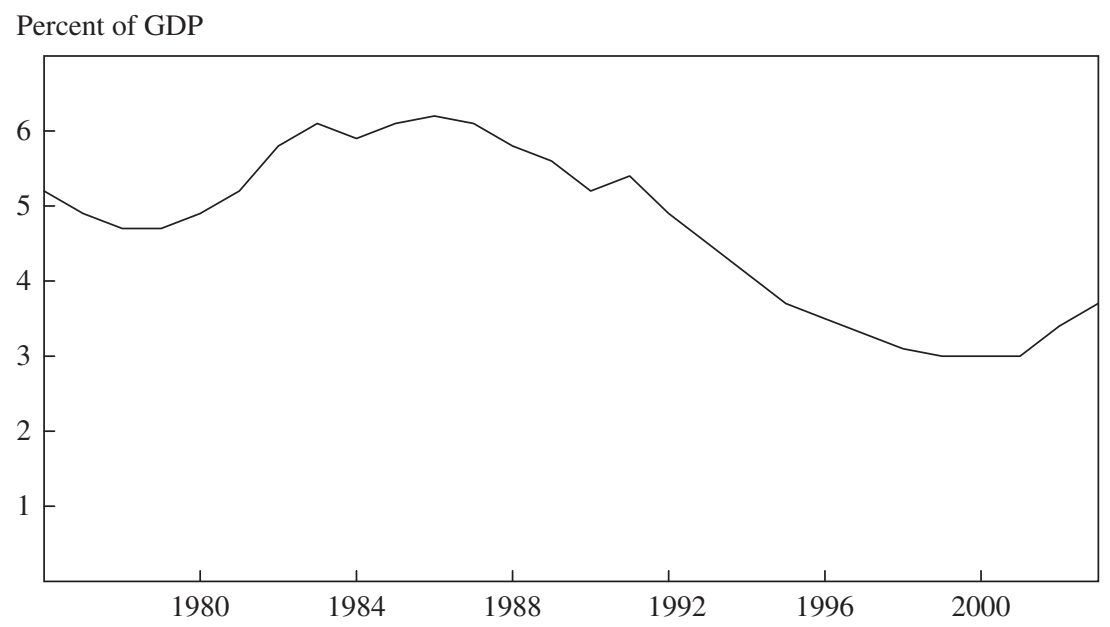

Source: CBO.

Valerie Ramey and Shapiro, augmented to include the military buildup in $2002 .{ }^{142} \mathrm{We}$ are skeptical that this variable is capturing significant shifts in defense spending, however. The Engen-Hubbard indicator variable is set equal to 1 only in 1980 and 2002. Yet increases in defense spending as a share of GDP were larger in 1981, 1982, 1983, and 2003 than in 1980 (figure 10). Another concern is that a sustained defense buildup should have lasting effects on interest rates, not a one-year effect as their dummy variable implies. Moreover, the decline in defense spending following the collapse of the Soviet Union might also rightfully be considered a noteworthy event in trends in defense spending. ${ }^{143}$ For these reasons we use actual defense spending as a share of GDP as a control variable, rather than the dummy variable.

Because some of the regression results suggested evidence of first-order autocorrelation in the error term, we use robust standard errors when esti-

142. Ramey and Shapiro (1998).

143. It is also worth noting that, in Ramey and Shapiro (1998, figure 6d), the effect on interest rates of a defense spending shock in their model dies out after five years, so that there ought not be an impact on the five-year ahead, ten-year interest rate in the first place. 
mation is undertaken using OLS; we also present the results using maximum likelihood to estimate a first-order autoregressive model. ${ }^{144}$

\section{Results}

PROJECTED FISCAL POLICY AND FORWARD INTEREST RATES. Table 6 reports results of OLS regressions in which the real forward (five-yearahead) long-term interest rate is the dependent variable. The findings leave two broad impressions. First, a robust, economically and statistically significant relationship is observed between forward long-term real interest rates and projected fiscal imbalances. Second, the $R^{2}$ statistics show that there is more information in the projected deficit variables than in the projected debt variables.

We begin with the simplest formulations (columns 6-1 through 6-4), which include only the projected fiscal policy measure and the projected GDP growth rate as control variables. An increase five years out in the projected debt of 1 percent of GDP (column 6-1) raises the real forward long-term interest rate by 4.9 basis points. An increase in the projected unified deficit equal to 1 percent of GDP (column 6-2) raises the forward long-term real interest rate by 29 basis points. An increase in the projected primary deficit of 1 percent of GDP (column 6-3) is associated with a still-larger impact on the forward long-term rate of 40 basis points. When revenue and primary outlays are entered separately, a projected reduction in revenue of 1 percent of GDP five years out is estimated to raise the forward long-term rate by 42 basis points, and a projected increase in outlays of the same magnitude and timing raises the forward long-term rate by 37 basis points. All of these estimates are significantly different from zero.

Adding a recession dummy and a term interacting the dummy with the fiscal policy variable (columns 6-5 through 6-8) raises the estimated coefficients on the fiscal variables slightly: the coefficient on the projected primary deficit, for example, rises from 40 to 45 basis points. The coefficients on the terms interacting the recession dummy and the projected fiscal measures suggest that a given fiscal projection has a smaller (in absolute value) effect on interest rates during a recession than during a period of full

144. Estimation is undertaken using the "arima" command in the STATA statistical software package. 
Table 6. OLS Estimates of the Effects of Projected Fiscal Variables on Real Forward Ten-Year Treasury Rates ${ }^{\mathrm{a}}$

\begin{tabular}{|c|c|c|c|c|c|c|c|c|c|c|c|c|}
\hline \multirow[b]{2}{*}{ Independent variable } & \multicolumn{12}{|c|}{ Regression } \\
\hline & $6-1$ & $6-2$ & $6-3$ & $6-4$ & $6-5$ & $6-6$ & $6-7$ & $6-8$ & $6-9$ & $6-10$ & $6-11$ & $6-12$ \\
\hline \multicolumn{13}{|l|}{ Fiscal variables } \\
\hline Projected debt/GDP & $\begin{array}{c}0.049 \\
(0.016)\end{array}$ & & & & $\begin{array}{c}0.056 \\
(0.018)\end{array}$ & & & & $\begin{array}{c}0.038 \\
(0.012)\end{array}$ & & & \\
\hline Projected deficit/GDP & & $\begin{array}{c}0.293 \\
(0.068)\end{array}$ & & & & $\begin{array}{c}0.315 \\
(0.070)\end{array}$ & & & & $\begin{array}{c}0.282 \\
(0.072)\end{array}$ & & \\
\hline $\begin{array}{l}\text { Projected primary } \\
\text { deficit/GDP }\end{array}$ & & & $\begin{array}{c}0.395 \\
(0.100)\end{array}$ & & & & $\begin{array}{c}0.445 \\
(0.091)\end{array}$ & & & & $\begin{array}{c}0.388 \\
(0.099)\end{array}$ & \\
\hline Projected revenue/GDP & & & & $\begin{array}{c}-0.424 \\
(0.203)\end{array}$ & & & & $\begin{array}{c}-0.531 \\
(0.130)\end{array}$ & & & & $\begin{array}{c}-0.292 \\
(0.133)\end{array}$ \\
\hline $\begin{array}{l}\text { Projected primary } \\
\text { outlays/GDP }\end{array}$ & & & & $\begin{array}{c}0.370 \\
(0.113)\end{array}$ & & & & $\begin{array}{c}0.391 \\
(0.141)\end{array}$ & & & & $\begin{array}{c}0.430 \\
(0.219)\end{array}$ \\
\hline \multicolumn{13}{|c|}{ Recession dummy and interactions } \\
\hline Recession dummy & & & & & $\begin{array}{c}2.913 \\
(0.554)\end{array}$ & $\begin{array}{l}1.615 \\
(0.396)\end{array}$ & $\begin{array}{l}1.128 \\
(0.484)\end{array}$ & $\begin{array}{c}-6.731 \\
(4.350)\end{array}$ & $\begin{array}{c}0.870 \\
(1.031)\end{array}$ & $\begin{array}{c}0.897 \\
(0.344)\end{array}$ & $\begin{array}{c}0.719 \\
(0.334)\end{array}$ & $\begin{array}{c}6.555 \\
(6.634)\end{array}$ \\
\hline $\begin{array}{l}\text { Recession dummy } \times \text { projected } \\
\text { debt/GDP }\end{array}$ & & & & & $\begin{array}{l}-0.043 \\
(0.025)\end{array}$ & & & & $\begin{array}{c}-0.012 \\
(0.023)\end{array}$ & & & \\
\hline $\begin{array}{l}\text { Recession dummy } \times \text { projected } \\
\text { deficit/GDP }\end{array}$ & & & & & & $\begin{array}{c}-0.178 \\
(0.109)\end{array}$ & & & & $\begin{array}{r}-0.099 \\
(0.053)\end{array}$ & & \\
\hline $\begin{array}{l}\text { Recession dummy } \times \text { projected } \\
\text { primary deficit/GDP }\end{array}$ & & & & & & & $\begin{array}{c}-0.258 \\
(0.147)\end{array}$ & & & & $\begin{array}{l}-0.152 \\
(0.075)\end{array}$ & \\
\hline $\begin{array}{l}\text { Recession dummy } \times \text { projected } \\
\text { revenue/GDP }\end{array}$ & & & & & & & & $\begin{array}{c}0.380 \\
(0.127)\end{array}$ & & & & $\begin{array}{c}0.030 \\
(0.157)\end{array}$ \\
\hline $\begin{array}{l}\text { Recession dummy } \times \text { projected } \\
\text { primary outlays/GDP }\end{array}$ & & & & & & & & $\begin{array}{c}0.057 \\
(0.173)\end{array}$ & & & & $\begin{array}{c}-0.356 \\
(0.229)\end{array}$ \\
\hline
\end{tabular}


Control variables

Oil price

Equity premium ${ }^{\mathrm{b}}$

Defense spending/GDP

Federal Reserve holdings of Treasuries

Federal Reserve purchases of Treasuries

Projected GDP growth rate

\section{Constant}

Adjusted $R^{2}$

\begin{tabular}{|c|c|c|c|c|c|c|c|c|c|c|c|}
\hline & & & & & & & & $\begin{array}{c}0.048 \\
(0.017) \\
-0.283 \\
(0.161) \\
-0.041 \\
(0.179) \\
-0.208 \\
(0.345)\end{array}$ & $\begin{array}{c}0.023 \\
(0.019) \\
-0.293 \\
(0.134) \\
-0.079 \\
(0.141)\end{array}$ & $\begin{array}{c}0.015 \\
(0.020) \\
-0.338 \\
(0.143) \\
0.012 \\
(0.148)\end{array}$ & $\begin{array}{c}0.023 \\
(0.022) \\
-0.377 \\
(0.175) \\
-0.028 \\
(0.195)\end{array}$ \\
\hline & & & & & & & & & $\begin{array}{c}-0.743 \\
(0.755)\end{array}$ & $\begin{array}{c}-0.690 \\
(0.741)\end{array}$ & $\begin{array}{c}-0.602 \\
(0.821)\end{array}$ \\
\hline $\begin{array}{c}0.555 \\
(0.438)\end{array}$ & $\begin{array}{c}0.278 \\
(0.300)\end{array}$ & $\begin{array}{c}0.185 \\
(0.289)\end{array}$ & $\begin{array}{c}0.204 \\
(0.264)\end{array}$ & $\begin{array}{c}0.296 \\
(0.406)\end{array}$ & $\begin{array}{c}0.034 \\
(0.233)\end{array}$ & $\begin{array}{c}-0.053 \\
(0.205)\end{array}$ & $\begin{array}{c}-0.001 \\
(0.208)\end{array}$ & $\begin{array}{c}0.152 \\
(0.585)\end{array}$ & $\begin{array}{c}0.346 \\
(0.521)\end{array}$ & $\begin{array}{c}0.363 \\
(0.526)\end{array}$ & $\begin{array}{c}0.311 \\
(0.554)\end{array}$ \\
\hline 1.335 & 3.666 & 4.809 & 5.767 & 1.629 & 4.168 & 5.377 & 7.880 & 3.522 & 4.261 & 4.999 & 2.586 \\
\hline (1.593) & $(0.806)$ & (0.799) & (4.878) & (1.687) & $(0.689)$ & $(0.494)$ & (3.684) & $(2.276)$ & (0.924) & $(0.880)$ & $(5.275)$ \\
\hline .213 & .436 & .408 & .386 & .463 & .642 & .641 & .636 & .679 & .779 & .773 & .758 \\
\hline
\end{tabular}

Source: Authors' regressions using data from CBO; Laubach (2003); OMB; Bureau of Economic Analysis, National Income and Product Accounts; Financial Forecast Center; National Bureau of Economic Research; Federal Reserve.

a. Sample period for all regressions is 1976-2004. All projected variables are five-year projections. Numbers in parentheses are robust standard errors. Number of observations $N=29$.

b. Dividend component of national income as a percentage of the market value of corporate equity held (directly or indirectly) by households, minus the real ten-year Treasury yield, plus the real GDP growth rate projected five years ahead. The value of the premium in the quarter prior to the release of the projections is used. 
employment. Four of the five interaction terms have p-values below .12, and one of these is significant at the 1 percent level. This suggests that the effect of a projected deficit on forward long-term rates may be smaller if the economy is currently in recession than if it is not. This presents a puzzle, since it is unclear why a current recession should affect the relationship between the two future variables. ${ }^{145}$

Adding the other control variables (monetary policy, defense spending, the oil price, and the equity premium; columns 6-9 through 6-12) reduces the estimated coefficients on the fiscal variables slightly: The coefficient on the projected primary imbalance, for example, declines to 39 basis points (column 6-11). The interaction between the recession dummy and projected unified or primary deficits remains statistically and economically significant (columns 6-10 and 6-11). Many of the additional control variables enter with the expected sign, but few are statistically significant other than the equity premium, which enters negatively. ${ }^{146}$ The coefficient on real oil prices is positive and significant in the debt equation (column 6-9), but it is not statistically significant in the others. The coefficient on Federal Reserve open-market purchases is negative but not statistically significant. Defense spending enters with a negative coefficient, but it is not statistically significant.

Running the same regressions using the nominal forward long-term rate as the dependent variable and including inflationary expectations as a righthand-side variable (table 7) generates similar fiscal effects. The coefficient on the projected primary deficit, for example, ranges between 33 and 46 basis points. The results in tables 6 and 7 underscore a robust, statistically significant connection between forward long-term interest rates and projected fiscal policy outcomes.

Table 8 includes both projected debt and projected primary deficit variables in the same regressions. To avoid double counting, we use projected debt as a share of GDP at the end of year $t+4$ and primary budget mea-

(text continues on page 164)

145. Rubin, Orszag, and Sinai (2004) hypothesize, based mostly on Rubin's experience with real-world financial markets, that "it is possible during economic downturns that financial markets do not focus on long-term fiscal issues; if this is the case, the effect of the fiscal deterioration on long-term interest rates will manifest itself only as the economy recovers." We have not evaluated whether arbitrage based on this evidence would generate expected profits after taking into account trading costs and other factors.

146. The same result is observed in Laubach (2003) and Engen and Hubbard (2004). 
Table 7. OLS Estimates of the Effects of Projected Fiscal Variables on Nominal Forward Ten-Year Treasury Rates ${ }^{\mathrm{a}}$

\begin{tabular}{|c|c|c|c|c|c|c|c|c|c|c|c|c|}
\hline \multirow[b]{2}{*}{ Independent variable } & \multicolumn{12}{|c|}{ Regression } \\
\hline & $7-1$ & $7-2$ & $7-3$ & $7-4$ & $7-5$ & $7-6$ & $7-7$ & $7-8$ & $7-9$ & $7-10$ & $7-11$ & $7-12$ \\
\hline \multicolumn{13}{|l|}{ Fiscal variables } \\
\hline Projected debt/GDP & $\begin{array}{c}0.035 \\
(0.019)\end{array}$ & & & & $\begin{array}{l}0.056 \\
(0.020)\end{array}$ & & & & $\begin{array}{c}0.038 \\
(0.011)\end{array}$ & & & \\
\hline Projected deficit/GDP & & $\begin{array}{l}0.250 \\
(0.096)\end{array}$ & & & & $\begin{array}{c}0.351 \\
(0.085)\end{array}$ & & & & $\begin{array}{l}0.281 \\
(0.073)\end{array}$ & & \\
\hline $\begin{array}{l}\text { Projected primary } \\
\text { deficit/GDP }\end{array}$ & & & $\begin{array}{c}0.329 \\
(0.127)\end{array}$ & & & & $\begin{array}{c}0.464 \\
(0.112)\end{array}$ & & & & $\begin{array}{c}0.384 \\
(0.098)\end{array}$ & \\
\hline Projected revenue/GDP & & & & $\begin{array}{l}-0.400 \\
(0.180)\end{array}$ & & & & $\begin{array}{r}-0.527 \\
(0.126)\end{array}$ & & & & $\begin{array}{c}-0.229 \\
(0.123)\end{array}$ \\
\hline $\begin{array}{l}\text { Projected primary } \\
\text { outlays/GDP }\end{array}$ & & & & $\begin{array}{c}0.245 \\
(0.147)\end{array}$ & & & & $\begin{array}{c}0.398 \\
(0.256)\end{array}$ & & & & $\begin{array}{c}0.458 \\
(0.238)\end{array}$ \\
\hline \multicolumn{13}{|c|}{ Recession dummy and interactions } \\
\hline Recession dummy & & & & & $\begin{array}{c}2.874 \\
(0.691)\end{array}$ & $\begin{array}{c}1.850 \\
(0.491)\end{array}$ & $\begin{array}{c}1.201 \\
(0.512)\end{array}$ & $\begin{array}{l}-6.515 \\
(6.437)\end{array}$ & $\begin{array}{c}1.243 \\
(1.168)\end{array}$ & $\begin{array}{c}0.988 \\
(0.432)\end{array}$ & $\begin{array}{c}0.750 \\
(0.347)\end{array}$ & $\begin{array}{c}9.254 \\
(7.462)\end{array}$ \\
\hline $\begin{array}{l}\text { Recession dummy } \times \text { projected } \\
\text { debt/GDP }\end{array}$ & & & & & $\begin{array}{l}-0.042 \\
(0.026)\end{array}$ & & & & $\begin{array}{l}-0.021 \\
(0.030)\end{array}$ & & & \\
\hline $\begin{array}{l}\text { Recession dummy } \times \text { projected } \\
\text { deficit/GDP }\end{array}$ & & & & & & $\begin{array}{r}-0.206 \\
(0.122)\end{array}$ & & & & $\begin{array}{l}-0.105 \\
(0.057)\end{array}$ & & \\
\hline $\begin{array}{l}\text { Recession dummy } \times \text { projected } \\
\text { primary deficit/GDP }\end{array}$ & & & & & & & $\begin{array}{l}-0.271 \\
(0.160)\end{array}$ & & & & $\begin{array}{c}-0.149 \\
(0.074)\end{array}$ & \\
\hline $\begin{array}{l}\text { Recession dummy } \times \text { projected } \\
\text { revenue/GDP }\end{array}$ & & & & & & & & $\begin{array}{c}0.375 \\
(0.130)\end{array}$ & & & & $\begin{array}{l}-0.037 \\
(0.159)\end{array}$ \\
\hline $\begin{array}{l}\text { Recession dummy } \times \text { projected } \\
\text { primary outlays/GDP }\end{array}$ & & & & & & & & $\begin{array}{l}0.050 \\
(0.254)\end{array}$ & & & & $\begin{array}{l}-0.430 \\
(0.263)\end{array}$ \\
\hline
\end{tabular}


Table 7. OLS Estimates of the Effects of Projected Fiscal Variables on Nominal Forward Ten-Year Treasury Rates ${ }^{\text {(continued })}$

\begin{tabular}{|c|c|c|c|c|c|c|c|c|c|c|c|c|}
\hline \multirow[b]{2}{*}{ Independent variable } & \multicolumn{12}{|c|}{ Regression } \\
\hline & $7-1$ & $7-2$ & $7-3$ & $7-4$ & $7-5$ & $7-6$ & $7-7$ & $7-8$ & $7-9$ & $7-10$ & $7-11$ & $7-12$ \\
\hline \multicolumn{13}{|l|}{ Control variables } \\
\hline Oil price & & & & & & & & & $\begin{array}{c}0.052 \\
(0.018)\end{array}$ & $\begin{array}{c}0.027 \\
(0.020)\end{array}$ & $\begin{array}{c}0.017 \\
(0.020)\end{array}$ & $\begin{array}{c}0.031 \\
(0.021)\end{array}$ \\
\hline Equity premium ${ }^{\mathrm{b}}$ & & & & & & & & & $\begin{array}{l}-0.244 \\
(0.136)\end{array}$ & $\begin{array}{c}-0.275 \\
(0.134)\end{array}$ & $\begin{array}{l}-0.330 \\
(0.142)\end{array}$ & $\begin{array}{r}-0.370 \\
(0.168)\end{array}$ \\
\hline Defense spending/GDP & & & & & & & & & $\begin{array}{c}0.055 \\
(0.275)\end{array}$ & $\begin{array}{c}0.011 \\
(0.230)\end{array}$ & $\begin{array}{c}0.051 \\
(0.235)\end{array}$ & $\begin{array}{c}0.056 \\
(0.259)\end{array}$ \\
\hline $\begin{array}{l}\text { Federal Reserve holdings } \\
\text { of Treasuries }\end{array}$ & & & & & & & & & $\begin{array}{c}-0.367 \\
(0.412)\end{array}$ & & & \\
\hline $\begin{array}{l}\text { Federal Reserve purchases } \\
\text { of Treasuries }\end{array}$ & & & & & & & & & & $\begin{array}{l}-0.786 \\
(0.702)\end{array}$ & $\begin{array}{l}-0.707 \\
(0.733)\end{array}$ & $\begin{array}{c}-0.615 \\
(0.804)\end{array}$ \\
\hline Projected GDP growth rate & $\begin{array}{l}-0.169 \\
(0.598)\end{array}$ & $\begin{array}{c}-0.078 \\
(0.443)\end{array}$ & $\begin{array}{l}-0.248 \\
(0.385)\end{array}$ & $\begin{array}{c}-0.265 \\
(0.378)\end{array}$ & $\begin{array}{c}0.273 \\
(0.525)\end{array}$ & $\begin{array}{c}0.274 \\
(0.370)\end{array}$ & $\begin{array}{c}0.042 \\
(0.333)\end{array}$ & $\begin{array}{c}0.011 \\
(0.378)\end{array}$ & $\begin{array}{c}0.228 \\
(0.635)\end{array}$ & $\begin{array}{c}0.393 \\
(0.551)\end{array}$ & $\begin{array}{c}0.372 \\
(0.552)\end{array}$ & $\begin{array}{c}0.335 \\
(0.594)\end{array}$ \\
\hline Expected inflation $^{c}$ & $\begin{array}{c}1.327 \\
(0.172)\end{array}$ & $\begin{array}{l}1.184 \\
(0.194)\end{array}$ & $\begin{array}{c}1.236 \\
(0.179)\end{array}$ & $\begin{array}{l}1.275 \\
(0.165)\end{array}$ & $\begin{array}{l}1.012 \\
(0.151)\end{array}$ & $\begin{array}{c}0.858 \\
(0.153)\end{array}$ & $\begin{array}{c}0.940 \\
(0.149)\end{array}$ & $\begin{array}{c}0.989 \\
(0.225)\end{array}$ & $\begin{array}{c}0.809 \\
(0.278)\end{array}$ & $\begin{array}{c}0.878 \\
(0.209)\end{array}$ & $\begin{array}{c}0.949 \\
(0.203)\end{array}$ & $\begin{array}{c}0.847 \\
(0.228)\end{array}$ \\
\hline Constant & $\begin{array}{c}2.740 \\
(1.907)\end{array}$ & $\begin{array}{c}4.057 \\
(0.875)\end{array}$ & $\begin{array}{l}5.088 \\
(0.722)\end{array}$ & $\begin{array}{l}7.874 \\
(3.774)\end{array}$ & $\begin{array}{l}1.678 \\
(1.851)\end{array}$ & $\begin{array}{l}3.939 \\
(0.739)\end{array}$ & $\begin{array}{l}5.340 \\
(0.506)\end{array}$ & $\begin{array}{c}7.671 \\
(5.871)\end{array}$ & $\begin{array}{l}4.103 \\
(2.050)\end{array}$ & $\begin{array}{c}3.989 \\
(1.157)\end{array}$ & $\begin{array}{c}4.883 \\
(1.123)\end{array}$ & $\begin{array}{c}0.668 \\
(6.100)\end{array}$ \\
\hline Adjusted $R^{2}$ & .813 & .854 & .853 & .851 & .854 & .906 & .903 & .900 & .914 & .941 & .938 & .935 \\
\hline
\end{tabular}

Source: Authors' regressions using data from CBO; Laubach (2003); OMB; Bureau of Economic Analysis, National Income and Product Accounts; Financial Forecast Center; National Bureau of Economic Research; Federal Reserve.

a. Sample period for all regressions is 1976-2004. All projected variables are five-year projections. Numbers in parentheses are robust standard errors. Number of observations $N=29$.

b. Defined as in table 6 .

c. As constructed by Laubach (2003) 
Table 8. Further OLS Estimates of the Effects of Projected Fiscal Variables on Real Forward Ten-Year Treasury Rates ${ }^{\mathrm{a}}$

\begin{tabular}{|c|c|c|c|c|c|c|}
\hline \multirow[b]{2}{*}{ Independent variable } & \multicolumn{6}{|c|}{ Regression } \\
\hline & $8-1$ & $8-2$ & $8-3$ & $8-4$ & $8-5$ & $8-6$ \\
\hline \multicolumn{7}{|l|}{ Fiscal variables } \\
\hline Projected debt/GDP & $\begin{array}{c}-0.034 \\
(0.028)\end{array}$ & $\begin{array}{r}-0.038 \\
(0.033)\end{array}$ & $\begin{array}{c}-0.042 \\
(0.028)\end{array}$ & $\begin{array}{l}-0.046 \\
(0.030)\end{array}$ & $\begin{array}{l}-0.016 \\
(0.027)\end{array}$ & $\begin{array}{l}-0.017 \\
(0.043)\end{array}$ \\
\hline $\begin{array}{l}\text { Projected primary } \\
\text { deficit/GDP }\end{array}$ & $\begin{array}{c}0.541 \\
(0.176)\end{array}$ & & $\begin{array}{c}0.648 \\
(0.156)\end{array}$ & & $\begin{array}{l}0.475 \\
0.177\end{array}$ & \\
\hline Projected revenue/GDP & & $\begin{array}{l}-0.528 \\
(0.212)\end{array}$ & & $\begin{array}{r}-0.661 \\
(0.179)\end{array}$ & & $\begin{array}{l}-0.400 \\
(0.275)\end{array}$ \\
\hline $\begin{array}{l}\text { Projected primary } \\
\text { outlays/GDP }\end{array}$ & & $\begin{array}{c}0.582 \\
(0.233)\end{array}$ & & $\begin{array}{c}0.665 \\
(0.224)\end{array}$ & & $\begin{array}{c}0.559 \\
(0.386)\end{array}$ \\
\hline \multicolumn{7}{|l|}{ Recession dummy and interactions } \\
\hline Recession dummy & & & $\begin{array}{c}1.036 \\
(1.366)\end{array}$ & $\begin{array}{c}-5.343 \\
(4.138)\end{array}$ & $\begin{array}{l}1.315 \\
(0.825)\end{array}$ & $\begin{array}{c}4.925 \\
(7.757)\end{array}$ \\
\hline $\begin{array}{l}\text { Recession dummy } \times \text { projected } \\
\text { debt/GDP }\end{array}$ & & & $\begin{array}{l}-0.005 \\
(0.028)\end{array}$ & $\begin{array}{r}-0.008 \\
(0.022)\end{array}$ & $\begin{array}{r}-0.016 \\
(0.019)\end{array}$ & $\begin{array}{l}-0.013 \\
(0.020)\end{array}$ \\
\hline $\begin{array}{l}\text { Recession dummy } \times \text { projected } \\
\text { primary deficit/GDP }\end{array}$ & & & $\begin{array}{c}-0.349 \\
(0.195)\end{array}$ & & $\begin{array}{c}-0.163 \\
(0.156)\end{array}$ & \\
\hline $\begin{array}{l}\text { Recession dummy } \times \text { projected } \\
\text { revenue/GDP }\end{array}$ & & & & $\begin{array}{c}0.397 \\
(0.179)\end{array}$ & & $\begin{array}{c}0.083 \\
(0.268)\end{array}$ \\
\hline $\begin{array}{l}\text { Recession dummy } \times \text { projected } \\
\text { primary outlays/GDP }\end{array}$ & & & & $\begin{array}{l}-0.026 \\
(0.208)\end{array}$ & & $\begin{array}{l}-0.280 \\
(0.279)\end{array}$ \\
\hline \multicolumn{7}{|l|}{ Control variables } \\
\hline Oil price & & & & & $\begin{array}{c}0.003 \\
(0.020)\end{array}$ & $\begin{array}{c}0.005 \\
(0.034)\end{array}$ \\
\hline Equity premium ${ }^{\mathrm{b}}$ & & & & & $\begin{array}{l}-0.354 \\
(0.152)\end{array}$ & $\begin{array}{l}-0.380 \\
(0.187)\end{array}$ \\
\hline Defense spending/GDP & & & & & $\begin{array}{c}0.077 \\
(0.143)\end{array}$ & $\begin{array}{c}0.015 \\
(0.167)\end{array}$ \\
\hline $\begin{array}{l}\text { Federal Reserve purchases } \\
\text { of Treasuries }\end{array}$ & & & & & $\begin{array}{c}-0.628 \\
(0.749)\end{array}$ & $\begin{array}{c}-0.561 \\
(0.844)\end{array}$ \\
\hline Projected GDP growth rate & $\begin{array}{l}-0.133 \\
(0.440)\end{array}$ & $\begin{array}{l}-0.186 \\
(0.426)\end{array}$ & $\begin{array}{c}-0.446 \\
(0.277)\end{array}$ & $\begin{array}{l}-0.501 \\
(0.315)\end{array}$ & $\begin{array}{c}0.307 \\
(0.601)\end{array}$ & $\begin{array}{c}0.305 \\
(0.620)\end{array}$ \\
\hline Constant & $\begin{array}{l}7.235 \\
(2.347)\end{array}$ & $\begin{array}{c}6.547 \\
(4.848)\end{array}$ & $\begin{array}{c}8.429 \\
(1.852)\end{array}$ & $\begin{array}{c}8.676 \\
(3.994)\end{array}$ & $\begin{array}{l}5.947 \\
(2.127)\end{array}$ & $\begin{array}{c}3.337 \\
(5.651)\end{array}$ \\
\hline Adjusted $R^{2}$ & .416 & .393 & .662 & .664 & .761 & .738 \\
\hline
\end{tabular}

Source: Authors' regressions using data from CBO; Laubach (2003); OMB; Bureau of Economic Analysis, National Income and Product Accounts; Financial Forecast Center; National Bureau of Economic Research; Federal Reserve.

a. Regressions are similar to those in table 6 except that at least two fiscal variables (one of which is projected debt) are included in each equation. Sample period for all regressions is 1976-2004. All projected variables are five-year projections except the debt-GDP ratio, which is a four-year projection. Numbers in parentheses are robust standard errors. Number of observations $N=29$.

b. Defined as in table 6 . 
sures in year $t+5 .{ }^{147}$ In this "horse race" between stocks and flows, the deficit variables dominate. Indeed, the coefficient on the projected debt variable becomes statistically insignificant (and slightly negative), and the estimated effect of the projected deficit increases: whereas in table 6 we found an effect of 29 to 45 basis points for a 1-percent-of-GDP change in the projected primary variable (primary deficit, primary outlays, or revenue), table 8 shows an effect of 40 to 67 basis points once the analysis controls for projected debt-GDP ratios. The recession interaction is statistically significant in one of the regressions (column 8-4, for the interaction with revenue), but insignificant in the others. Of the other variables, only the equity premium remains statistically significant. The inclusion of both debt and deficit variables produces similar results when, as in table 7, the nominal forward interest rate is used as the dependent variable and inflationary expectations are included on the right-hand side (results not shown).

Table 9 shows results for the same specification as in table 8 but using a first-order autoregressive moving average (ARMA) model for the estimation, because some of the results (in particular, when the additional control variables are included) suggest autocorrelated errors. In these regressions the coefficient on the projections of the primary deficit, primary outlays, and revenue ranges between 44 and 67 basis points. Again, the coefficients on the debt variables are generally small, negative, and statistically insignificant, and some of the recession interaction terms are significant. We highlight the specification in column 9-5 as something of a central estimate and will use it as a baseline for our sensitivity analysis below. In that specification a 1-percent-of-GDP increase in the primary deficit projected five years in the future raises current forward rates by 53 basis points, controlling for a wide variety of other explanatory factors. ${ }^{148}$

PROJECTED FISCAL POLICY AND CURRENT LONG-TERM RATES. Table 10 shows regressions of the current real ten-year interest rate on projected future fiscal variables. In the specifications that include (besides GDP

(text continues on page 69)

147. Using projected debt at the end of $t+5$ and the deficit in $t+5$ would double-count the deficit in $t+5$. Likewise, using debt at the end of $t+4$ and the unified deficit in $t+5$ would effectively double-count interest payments in $t+5$, since they are already implied by the debt level at the end of $t+4$.

148. Estimates of the specifications in tables 6 through 9 in first-difference form led to similar coefficient estimates and large standard errors. 
Table 9. ARMA Estimates of the Effects of Projected Fiscal Variables on Real Forward Ten-Year Treasury Rates ${ }^{\mathrm{a}}$

\begin{tabular}{|c|c|c|c|c|c|c|}
\hline \multirow[b]{2}{*}{ Independent variable } & \multicolumn{6}{|c|}{ Regression } \\
\hline & $9-1$ & $9-2$ & $9-3$ & $9-4$ & $9-5$ & $9-6$ \\
\hline \multicolumn{7}{|l|}{ Fiscal variables } \\
\hline Projected debt/GDP & $\begin{array}{l}-0.029 \\
(0.031)\end{array}$ & $\begin{array}{l}-0.038 \\
(0.034)\end{array}$ & $\begin{array}{l}-0.047 \\
(0.026)\end{array}$ & $\begin{array}{l}-0.047 \\
(0.026)\end{array}$ & $\begin{array}{l}-0.013 \\
(0.017)\end{array}$ & $\begin{array}{l}-0.010 \\
(0.019)\end{array}$ \\
\hline Projected primary deficit/GDP & $\begin{array}{l}0.455 \\
(0.225)\end{array}$ & & $\begin{array}{c}0.673 \\
(0.169)\end{array}$ & & $\begin{array}{l}0.534 \\
(0.113)\end{array}$ & \\
\hline Projected revenue/GDP & & $\begin{array}{l}-0.442 \\
(0.219)\end{array}$ & & $\begin{array}{l}-0.672 \\
(0.171)\end{array}$ & & $\begin{array}{l}-0.508 \\
(0.154)\end{array}$ \\
\hline Projected primary outlays/GDP & & $\begin{array}{l}0.564 \\
(0.227)\end{array}$ & & $\begin{array}{c}0.669 \\
(0.201)\end{array}$ & & $\begin{array}{c}0.489 \\
(0.213)\end{array}$ \\
\hline \multicolumn{7}{|l|}{ Recession dummy and interactions } \\
\hline Recession dummy & & & $\begin{array}{c}0.770 \\
(1.511)\end{array}$ & $\begin{array}{l}-5.549 \\
(3.597)\end{array}$ & $\begin{array}{c}0.512 \\
(0.854)\end{array}$ & $\begin{array}{c}1.688 \\
(4.807)\end{array}$ \\
\hline $\begin{array}{l}\text { Recession dummy } \times \\
\text { projected debt/GDP }\end{array}$ & & & $\begin{array}{c}0.003 \\
(0.033)\end{array}$ & $\begin{array}{l}-0.003 \\
(0.029)\end{array}$ & $\begin{array}{c}0.013 \\
(0.021)\end{array}$ & $\begin{array}{c}0.015 \\
(0.022)\end{array}$ \\
\hline $\begin{array}{l}\text { Recession dummy } \times \text { projected } \\
\text { primary deficit/GDP }\end{array}$ & & & $\begin{array}{l}-0.385 \\
(0.231)\end{array}$ & & $\begin{array}{r}-0.330 \\
(0.159)\end{array}$ & \\
\hline $\begin{array}{l}\text { Recession dummy } \times \text { projected } \\
\text { revenue/GDP }\end{array}$ & & & & $\begin{array}{c}0.423 \\
(0.213)\end{array}$ & & $\begin{array}{c}0.295 \\
(0.180)\end{array}$ \\
\hline $\begin{array}{l}\text { Recession dummy } \times \text { projected } \\
\text { primary outlays/GDP }\end{array}$ & & & & $\begin{array}{l}-0.051 \\
(0.243)\end{array}$ & & $\begin{array}{l}-0.368 \\
(0.245)\end{array}$ \\
\hline \multicolumn{7}{|l|}{ Control variables } \\
\hline Oil price & & & & & $\begin{array}{l}-0.010 \\
(0.020)\end{array}$ & $\begin{array}{c}0.003 \\
(0.029)\end{array}$ \\
\hline Equity premium ${ }^{\mathrm{b}}$ & & & & & $\begin{array}{l}-0.447 \\
(0.118)\end{array}$ & $\begin{array}{l}-0.448 \\
(0.118)\end{array}$ \\
\hline Defense spending/GDP & & & & & $\begin{array}{c}0.029 \\
(0.063)\end{array}$ & $\begin{array}{c}0.032 \\
(0.085)\end{array}$ \\
\hline $\begin{array}{l}\text { Federal Reserve purchases } \\
\text { of Treasuries }\end{array}$ & & & & & $\begin{array}{l}-0.330 \\
(0.545)\end{array}$ & $\begin{array}{l}-0.297 \\
(0.585)\end{array}$ \\
\hline Projected GDP growth rate & $\begin{array}{l}-0.150 \\
(0.429)\end{array}$ & $\begin{array}{l}-0.250 \\
(0.407)\end{array}$ & $\begin{array}{l}-0.484 \\
(0.213)\end{array}$ & $\begin{array}{l}-0.506 \\
(0.259)\end{array}$ & $\begin{array}{c}0.775 \\
(0.560)\end{array}$ & $\begin{array}{c}0.734 \\
(0.565)\end{array}$ \\
\hline Constant & $\begin{array}{c}6.941 \\
(2.346)\end{array}$ & $\begin{array}{c}5.388 \\
(4.761)\end{array}$ & $\begin{array}{c}8.748 \\
(1.701)\end{array}$ & $\begin{array}{c}8.871 \\
(3.375)\end{array}$ & $\begin{array}{c}5.365 \\
(1.332)\end{array}$ & $\begin{array}{c}5.448 \\
(3.147)\end{array}$ \\
\hline $\mathrm{AR}(1)$ coefficient & $\begin{array}{c}0.331 \\
(0.308)\end{array}$ & $\begin{array}{c}0.346 \\
(0.280)\end{array}$ & $\begin{array}{l}-0.100 \\
(0.210)\end{array}$ & $\begin{array}{l}-0.061 \\
(0.214)\end{array}$ & $\begin{array}{l}-0.587 \\
(0.239)\end{array}$ & $\begin{array}{l}-0.588 \\
(0.232)\end{array}$ \\
\hline Wald $\chi^{2}$ & 52.409 & 56.816 & 419.014 & $71,263.451$ & $2,751.599$ & $39,603.831$ \\
\hline
\end{tabular}

Source: Authors' regressions using data from CBO; Laubach (2003); OMB; Bureau of Economic Analysis, National Income and Product Accounts; Financial Forecast Center; National Bureau of Economic Research; Federal Reserve.

a. Sample period for all regressions is 1976-2004. All projected variables are five-year projections except the debt-GDP ratio, which is a four-year projection. Numbers in parentheses are semirobust standard errors. Number of observations $N=29$.

b. Defined as in table 6 . 


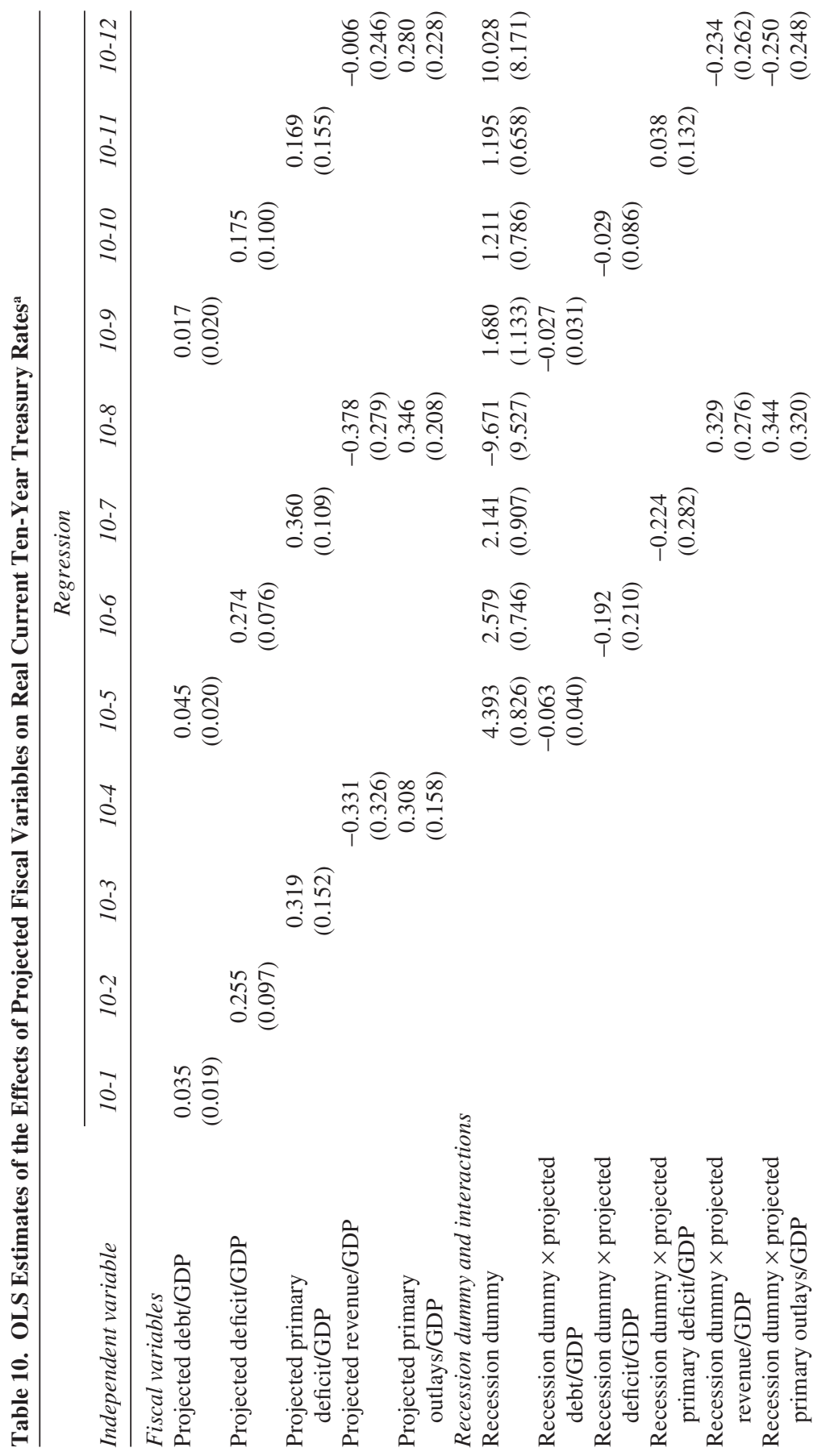




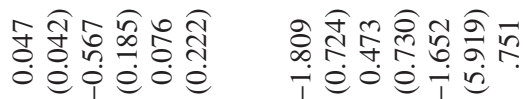

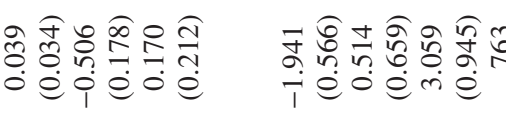

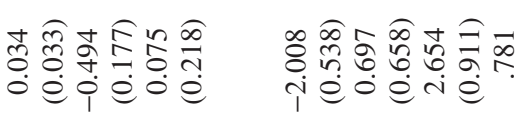

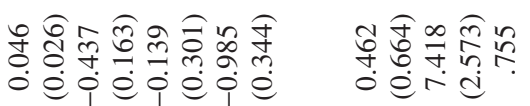

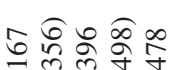
过等导 도용영 òme

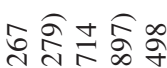
oैं तe 으증 วิㅇํㅇ

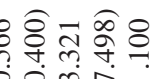
金守学向 o

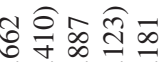
$\circ \stackrel{e}{-}$ مo 
growth) only fiscal variables or only fiscal and recession variables (columns 10-1 through 10-8), the coefficients on the fiscal variables tend to be somewhat smaller than when the forward long-term rate is used (table 6) but are still statistically significant. For example, the coefficient on the projected primary deficit is either 32 or 36 basis points. The coefficients become smaller and statistically insignificant when the additional control variables are included: the coefficient on the primary deficit falls to 17 basis points.

Notably, Federal Reserve holdings or purchases of Treasury securities, which did not affect forward long-term rates in tables 6 through 9, have an economically significant and statistically precise effect on current long-term rates in table 10 (and in tables 11 through 13). This suggests that different factors may affect current long-term rates than affect forward rates.

When current nominal long-term rates are used as the dependent variable (table 11), projected unified deficits and projected primary deficits each enter with a statistically significant coefficient of about 20 basis points in the regressions that include all of the control variables (columns 11-10 and 11-11, respectively). When current real rates are used and both the projected debt and projected primary deficit variables are included (table 12), the estimated coefficient on the latter increases to over 50 basis points in the specifications that include only fiscal variables or only fiscal and recession variables, but this effect disappears in the regressions that include all the control variables. The results are similar when nominal rates are used and when an AR(1) model is estimated (results not shown).

EFFECTS OF CURRENT FISCAL POLICY ON CURRENT LONG-TERM RATES. Table 13 presents regressions of the real current long-term interest rate on current fiscal variables. The fiscal variables are generally not statistically significant in these specifications, and they remain insignificant when the nominal rate is used, when an AR(1) model is estimated, and when both debt and deficit variables are entered simultaneously (results not shown).

\section{Sensitivity Analysis}

Table 14 presents results of our sensitivity analysis on the risk measure and the state-of-the-economy measure. The equity premium variable raises 


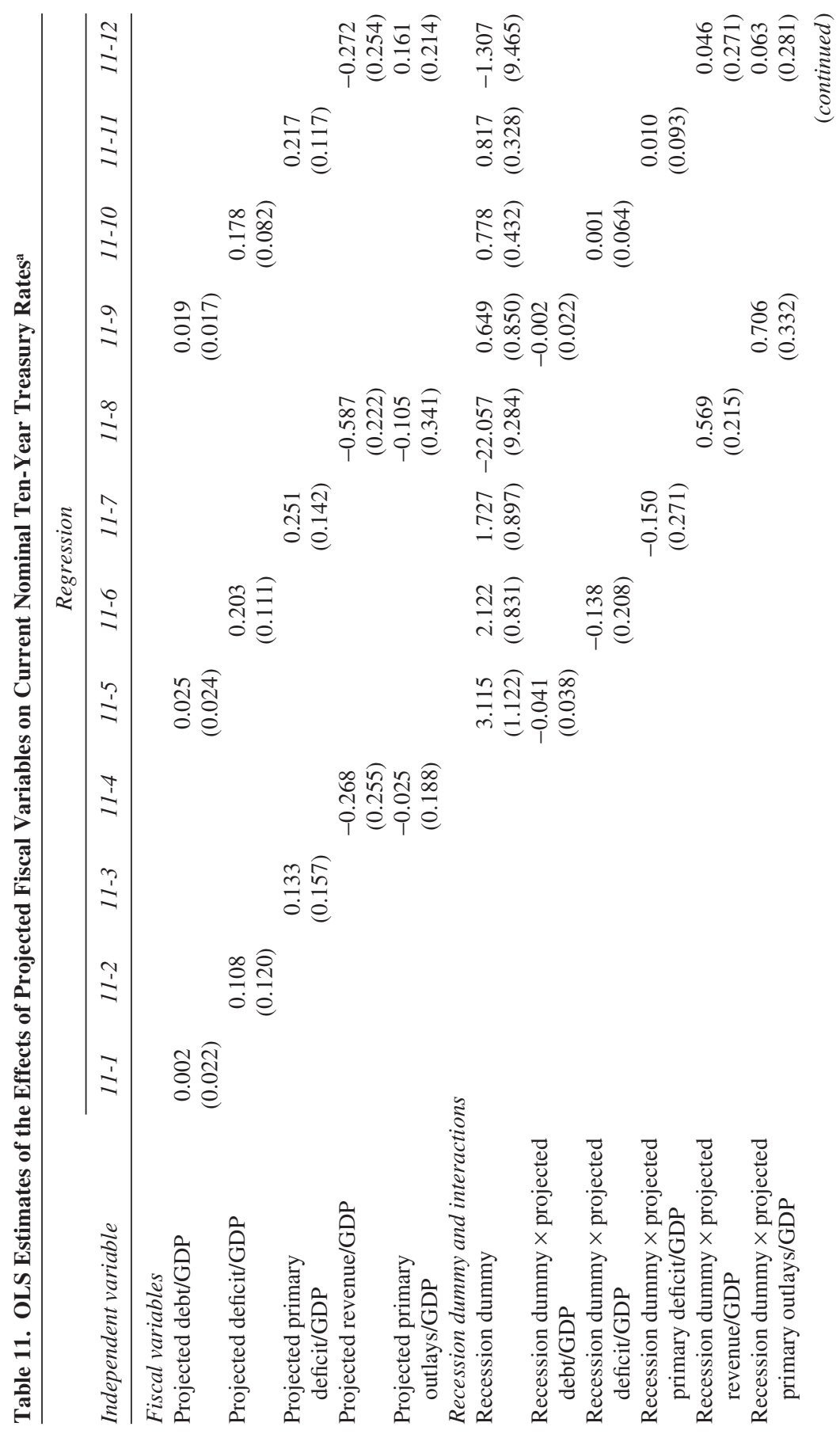




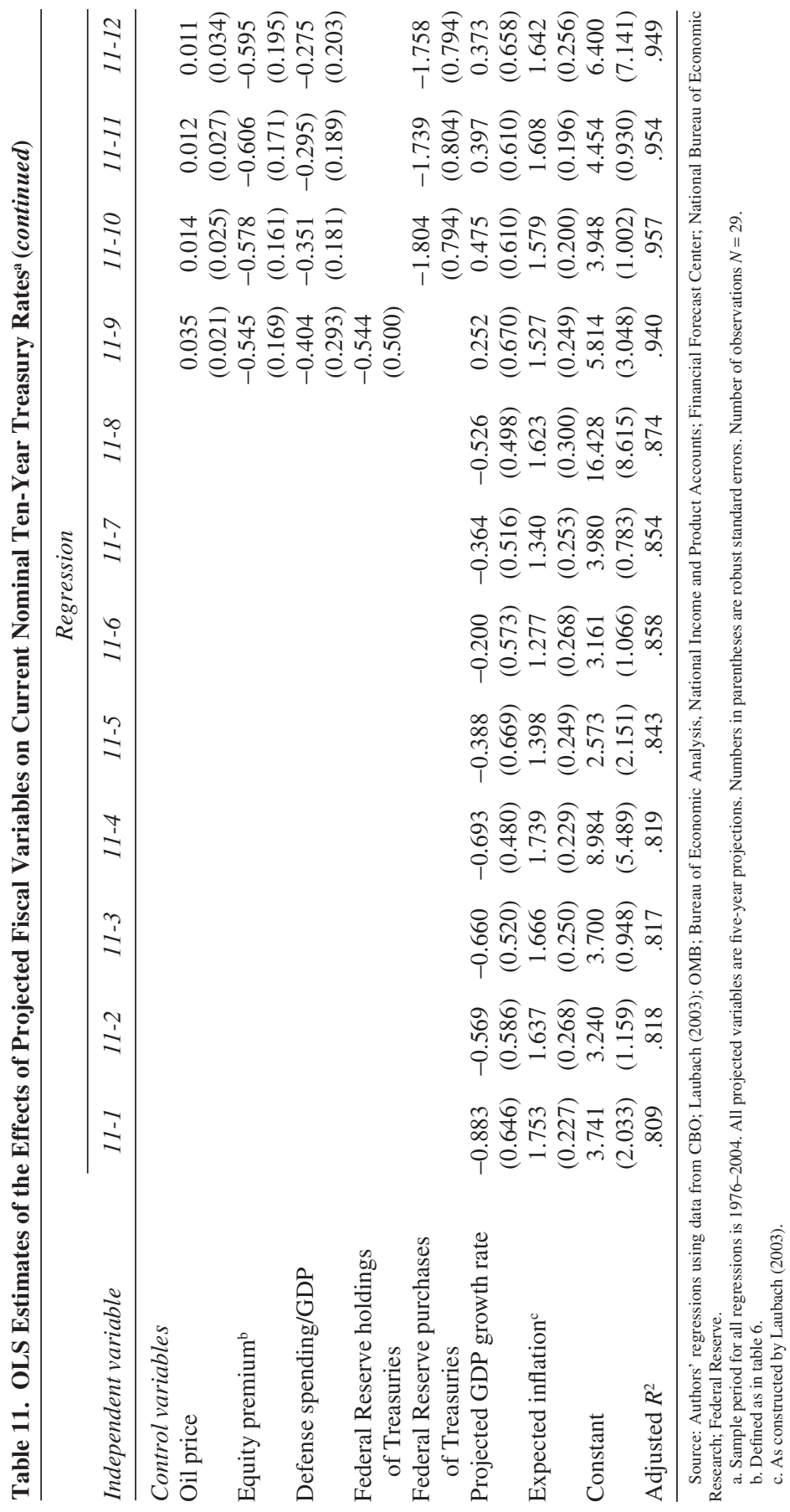


Table 12. Further OLS Estimates of the Effects of Projected Fiscal Variables on Real Current Ten-Year Treasury Rates ${ }^{\mathrm{a}}$

\begin{tabular}{|c|c|c|c|c|c|c|}
\hline \multirow[b]{2}{*}{ Independent variable } & \multicolumn{6}{|c|}{ Regression } \\
\hline & $12-1$ & $12-2$ & $12-3$ & $12-4$ & $12-5$ & $12-6$ \\
\hline \multicolumn{7}{|l|}{ Fiscal variables } \\
\hline Projected debt/GDP & $\begin{array}{c}-0.052 \\
(0.039)\end{array}$ & $\begin{array}{c}-0.062 \\
(0.041)\end{array}$ & $\begin{array}{l}-0.037 \\
(0.033)\end{array}$ & $\begin{array}{l}-0.050 \\
(0.031)\end{array}$ & $\begin{array}{c}0.019 \\
(0.028)\end{array}$ & $\begin{array}{r}0.017 \\
(0.037)\end{array}$ \\
\hline $\begin{array}{l}\text { Projected primary } \\
\text { deficit/GDP }\end{array}$ & $\begin{array}{c}0.541 \\
(0.276)\end{array}$ & & $\begin{array}{c}0.527 \\
(0.194)\end{array}$ & & $\begin{array}{c}0.085 \\
(0.198)\end{array}$ & \\
\hline Projected revenue/GDP & & $\begin{array}{r}-0.504 \\
(0.344)\end{array}$ & & $\begin{array}{r}-0.479 \\
(0.344)\end{array}$ & & $\begin{array}{r}0.026 \\
(0.348)\end{array}$ \\
\hline $\begin{array}{l}\text { Projected primary } \\
\text { outlays/GDP }\end{array}$ & & $\begin{array}{c}0.660 \\
(0.312)\end{array}$ & & $\begin{array}{c}0.655 \\
(0.281)\end{array}$ & & $\begin{array}{r}0.209 \\
(0.304)\end{array}$ \\
\hline \multicolumn{7}{|l|}{ Recession dummy and interactions } \\
\hline Recession dummy & & & $\begin{array}{c}3.677 \\
(2.272)\end{array}$ & $\begin{array}{l}-6.378 \\
(9.464)\end{array}$ & $\begin{array}{c}4.129 \\
(1.102)\end{array}$ & $\begin{array}{r}9.496 \\
(9.220)\end{array}$ \\
\hline $\begin{array}{l}\text { Recession dummy } \times \text { projected } \\
\text { debt/GDP }\end{array}$ & & & $\begin{array}{r}-0.050 \\
(0.047)\end{array}$ & $\begin{array}{l}-0.056 \\
(0.026)\end{array}$ & $\begin{array}{l}-0.076 \\
(0.022)\end{array}$ & $\begin{array}{c}-0.072 \\
(0.024)\end{array}$ \\
\hline $\begin{array}{l}\text { Recession dummy } \times \text { projected } \\
\text { primary deficit/GDP }\end{array}$ & & & $\begin{array}{c}-0.162 \\
(0.309)\end{array}$ & & $\begin{array}{l}0.304 \\
(0.174)\end{array}$ & \\
\hline $\begin{array}{l}\text { Recession dummy } \times \text { projected } \\
\text { revenue/GDP }\end{array}$ & & & & $\begin{array}{l}0.180 \\
(0.352)\end{array}$ & & $\begin{array}{r}-0.422 \\
(0.335)\end{array}$ \\
\hline $\begin{array}{l}\text { Recession dummy } \times \text { projected } \\
\text { primary outlays/GDP }\end{array}$ & & & & $\begin{array}{c}0.419 \\
(0.248)\end{array}$ & & $\begin{array}{r}0.128 \\
(0.248)\end{array}$ \\
\hline Control variables & & & & & & \\
\hline Oil price & & & & & $\begin{array}{c}0.024 \\
(0.033)\end{array}$ & $\begin{array}{r}0.026 \\
(0.049)\end{array}$ \\
\hline Equity premium ${ }^{\mathrm{b}}$ & & & & & $\begin{array}{l}-0.547 \\
(0.200)\end{array}$ & $\begin{array}{r}-0.585 \\
(0.207)\end{array}$ \\
\hline Defense spending/GDP & & & & & $\begin{array}{c}0.238 \\
(0.228)\end{array}$ & $\begin{array}{r}0.147 \\
(0.242)\end{array}$ \\
\hline $\begin{array}{l}\text { Federal Reserve purchases } \\
\text { of Treasuries }\end{array}$ & & & & & $\begin{array}{l}-2.199 \\
(0.656)\end{array}$ & $\begin{array}{r}-2.100 \\
(0.787)\end{array}$ \\
\hline Projected GDP growth rate & $\begin{array}{c}0.073 \\
(0.559)\end{array}$ & $\begin{array}{r}-0.081 \\
(0.495)\end{array}$ & $\begin{array}{c}-0.251 \\
(0.342)\end{array}$ & $\begin{array}{l}-0.493 \\
(0.474)\end{array}$ & $\begin{array}{c}0.745 \\
(0.837)\end{array}$ & $\begin{array}{r}0.741 \\
(0.903)\end{array}$ \\
\hline Constant & $\begin{array}{c}6.611 \\
(3.199)\end{array}$ & $\begin{array}{c}4.615 \\
(7.500)\end{array}$ & $\begin{array}{c}6.654 \\
(2.347)\end{array}$ & $\begin{array}{c}4.636 \\
(8.649)\end{array}$ & $\begin{array}{l}1.868 \\
(2.297)\end{array}$ & $\begin{array}{c}-1.993 \\
(7.340)\end{array}$ \\
\hline Adjusted $R^{2}$ & .146 & .119 & .488 & .537 & .785 & .767 \\
\hline
\end{tabular}

Source: Authors' regressions using data from CBO; Laubach (2003); OMB; Bureau of Economic Analysis, National Income and Product Accounts; Financial Forecast Center; National Bureau of Economic Research; Federal Reserve.

a. These regressions are similar to those in table 6 except that at least two fiscal variables (one of which is projected debt) are included in each equation. Sample period for all regressions is 1976-2004. All projected variables are five-year projections except the debt-GDP ratio, which is a four-year projection. Numbers in parentheses are robust standard errors. Number of observations $N=29$.

b. Defined as in table 6 . 


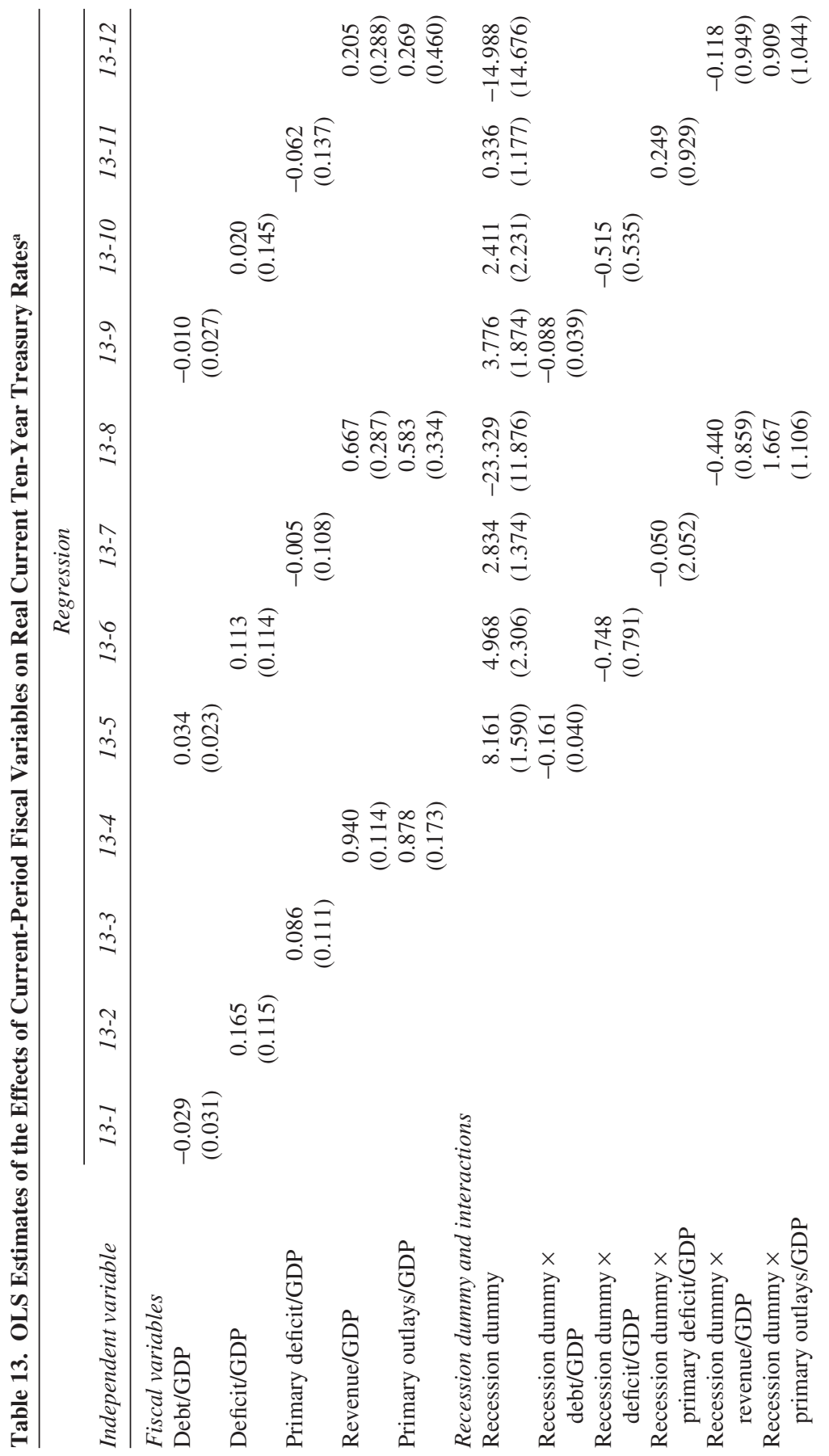




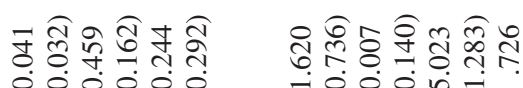

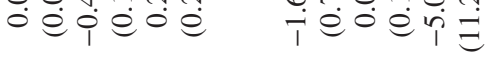

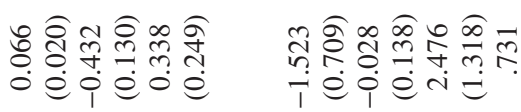

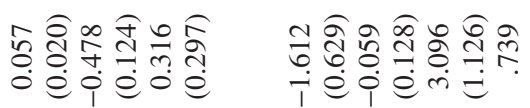

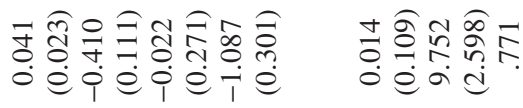

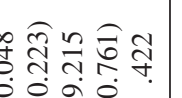
ㅇํㅇ

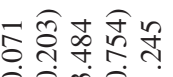

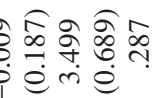

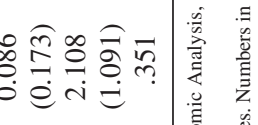
\& iे पे क्षे iैive

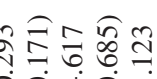
१९ंध

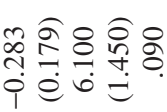

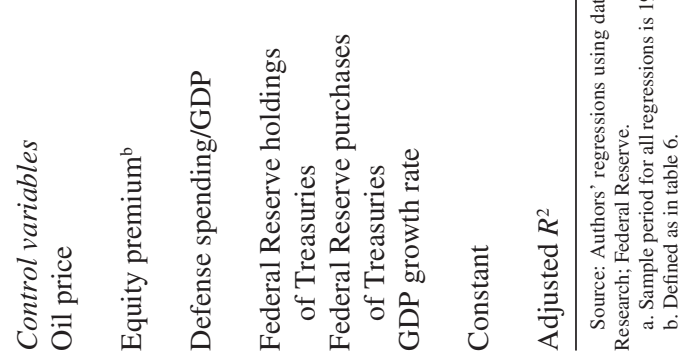




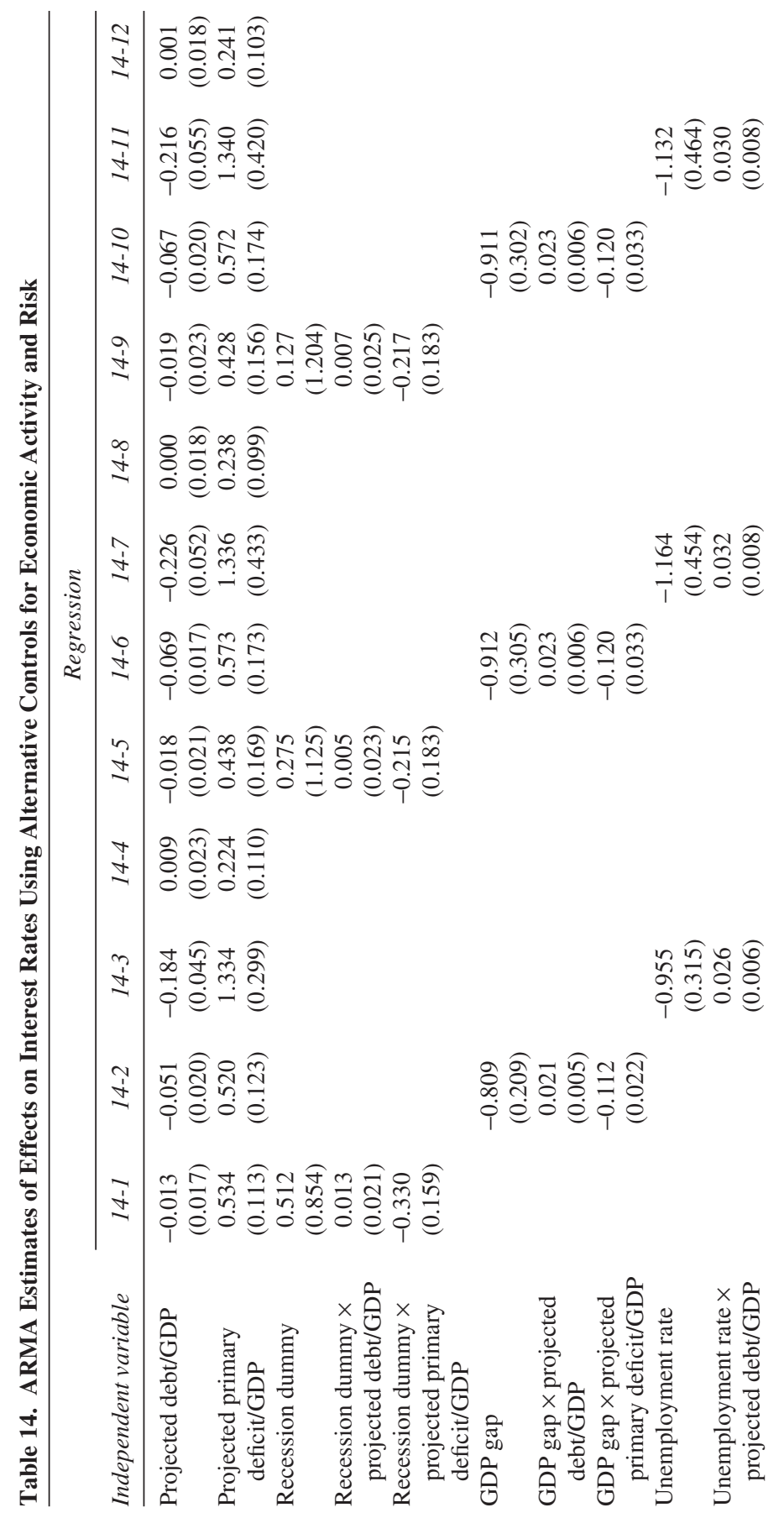


in

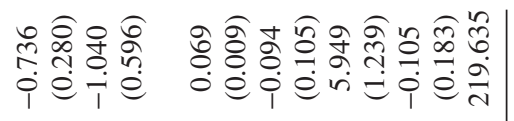

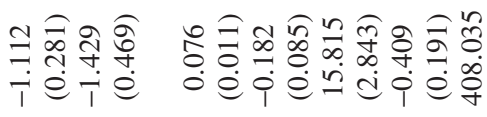

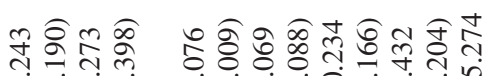

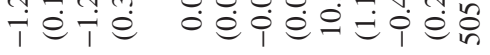

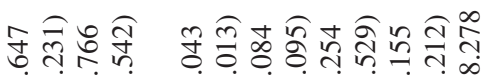
iép 0ं

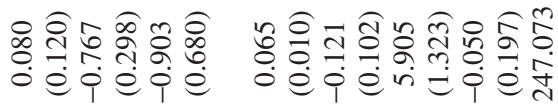

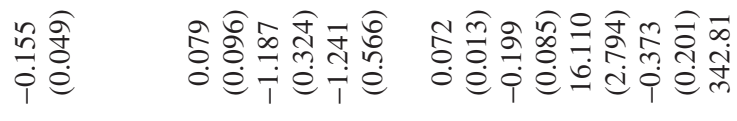

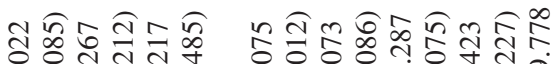

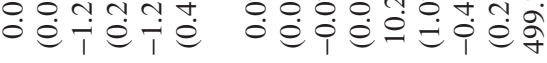

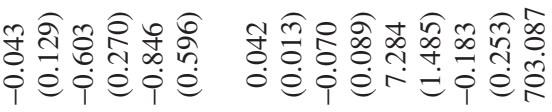

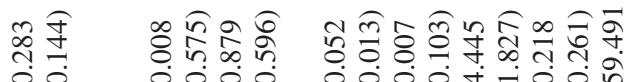

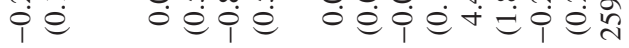

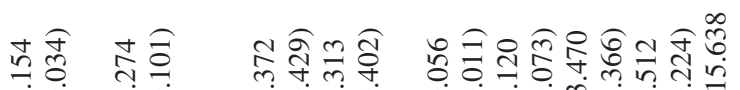
i仓

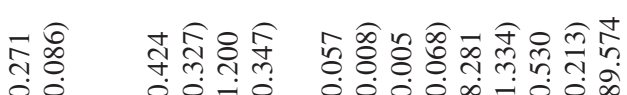

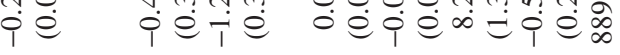

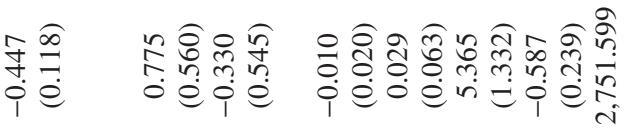

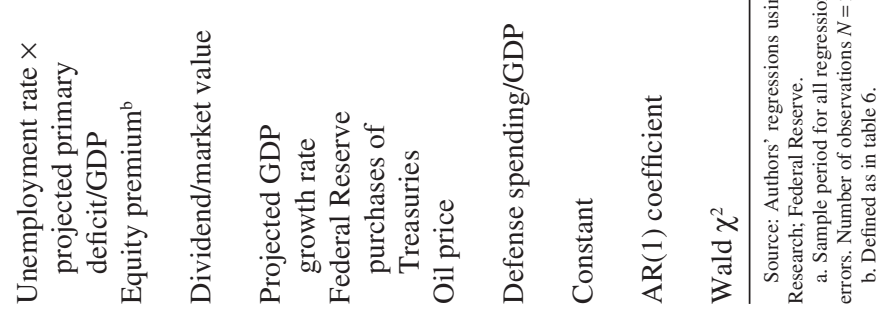


a number of issues. A change in the ratio of the dividend yield to market value could imply either a change in the return on all assets or a shift in preferences for stocks versus bonds. In addition, the equity premium variable includes a measure of the previous period's long-term interest rates, which might create endogeneity problems. ${ }^{149} \mathrm{We}$ therefore examine the effects of dropping the interest rate component of the equity premiumand thus entering the dividend-market value ratio in lieu of the equity premium - and of omitting both risk variables. The recession dummy also raises some concerns, since it is discontinuous and takes the value of 1 only in 1980, 1981, 1982, and 1991. ${ }^{150}$ To explore other options, we perform regressions using the GDP gap, the unemployment rate, or no control for the current state of the economy. ${ }^{151}$

Column 14-1 in table 14 reproduces the estimates from the regression reported in column 9-5 of table 9, which includes both the recession dummy and the equity premium. The next two columns use alternative measures of the state of the economy, and column 14-4 uses none. Columns 14-5 through 14-8 repeat the first four specifications using the dividend yield instead of the equity premium, and columns 14-9 through 14-12 include no risk measure. (Thus, column 14-12 includes no control for either risk or the state of the economy.) In all twelve specifications, projected primary deficits in year $t+5$ have positive, precisely estimated, and substantial impacts on forward long-term rates; in contrast, projected ratios of public debt to GDP never show a positive significant effect. Controlling for the GDP gap (columns 14-2, 14-6, and 14-10) generates fiscal policy effects similar to those using the recession measure. Controlling for the unemployment rate (columns 14-3, 14-7, and 14-11) generates very large effects of deficits on interest rates. Not controlling for the state of the economy (columns 14-4, 14-8, and 14-12) generates much smaller effects of fiscal

149. Laubach (2003) uses as an instrument for the equity premium variable the previous period's value of the term and finds that it does not affect his results.

150. The 2001 recession began in March and ended in November and thus did not overlap with either the January 2001 or January 2002 CBO forecasts.

151. The last specification follows that of Laubach (2003) and Engen and Hubbard (2004). It is appropriate to note, however, that our goal in including the recession variable is not just to control for the state of the economy, but also to explore whether the effects of future projected fiscal policy outcomes were systematically different in a recession, perhaps because participants in financial markets have shorter horizons during such periods. Controlling for smoother measures, such as the GDP gap or the unemployment rate, may not provide as clean a test of that hypothesis. 
policy on interest rates. This suggests that, even when one examines forward long-term rates, it is important to control for the current state of the economy. Alternative specifications of the risk variable do not affect the impact of projected fiscal policy on interest rates.

Table 15 examines the sensitivity of the results across time periods and fiscal policy measures. Dropping the years after 2000 allows an analysis that is independent of the Bush tax cuts and the recent recession. Dropping the years before 1981 is interesting, because Christopher House shows that, during the 1981-2004 period, the actual deficit in year $t$ is closely correlated with the projection in that year of the deficit in year $t+5 .{ }^{152}$ This raises two key questions: First, to what extent are the results in tables 6 through 9 for the whole period due to potentially unusual patterns in the 1976-81 period? Second, are the central results for projected fiscal policy in those tables merely masking the fact that current deficits affect future interest rates and that projected deficits happen to proxy well for current deficits during this period? ? $^{153}$

To address the first question, column 15-1 of table 15 again repeats the results from column 9-5 in table 9, and columns 15-2 and 15-3 show results of the same specification for different sample periods. The effect of projected fiscal policy on forward rates is similar in each of the three sample periods: between 42 and 57 basis points for each 1-percent-of-GDP change in the projected primary deficit. ${ }^{154}$ This shows that the effects of projected fiscal policy reported in tables 6 through 9 are not due just to the inclusion of data for the $1976-81$ period. ${ }^{155}$

152. See the comment by House following this paper.

153. The correlation between the deficit in period $t$ and the deficit in period $t+5$ that is predicted in period $t$ (both measured as a share of GDP) is 0.6 for the 1981-2004 period and 0.5 for 1976-2004. In contrast, the correlation between the actual deficit in period $t+5$ and the period $t+5$ deficit predicted in period $t$ is negative (between -.3 and -.5 ) in both periods. A regression of the projected five-year-ahead deficit on the current deficit yields a coefficient of about $0.8(t=5)$ in each of the subperiods. A regression of the projected five-year-ahead deficit on the actual outcome yields a coefficient less than 0.1 in absolute value. See Cohen and Follette (2003) for a discussion of the difficulties in projecting fiscal variables beyond a year or two.

154. This finding is consistent with Laubach's (2003) finding that his results are not sensitive to subperiods within the overall 1976-2004 sample period.

155. Note that the overall relationship between interest rates and fiscal policy could evolve over time for a wide variety of reasons, including increasing openness of the economy (which would tend to make the relationship weaker) and a broader use of government debt to hedge mortgage-backed securities (which could tend to make the relationship stronger). 


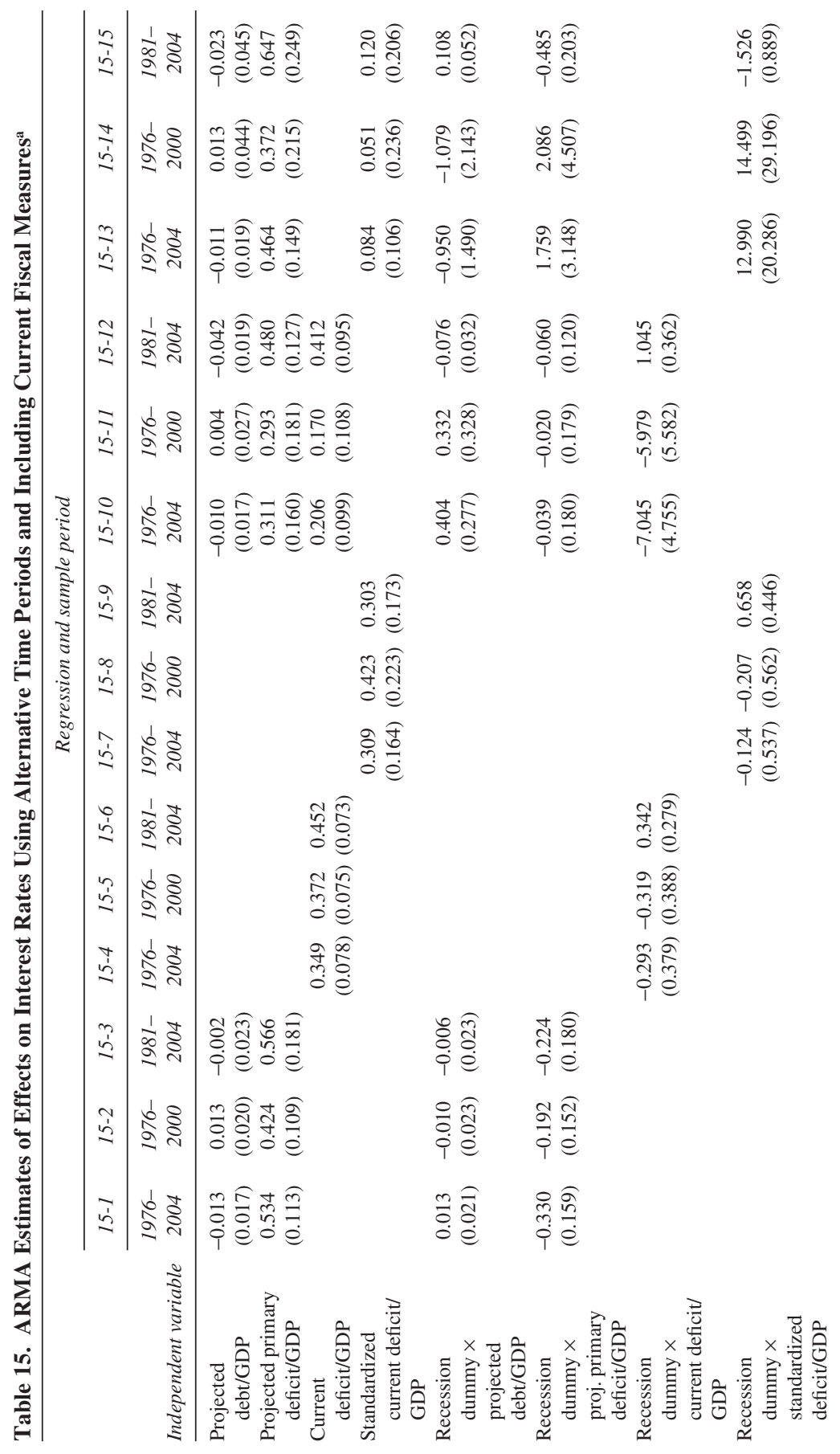




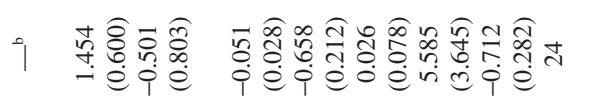

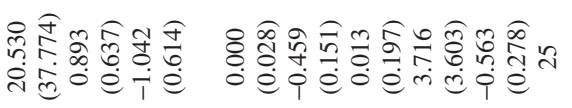

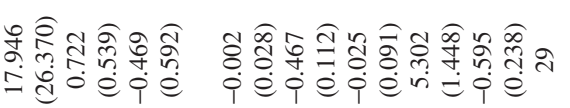
q

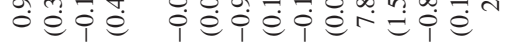

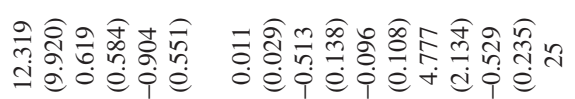

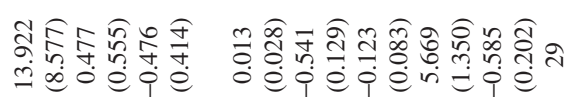

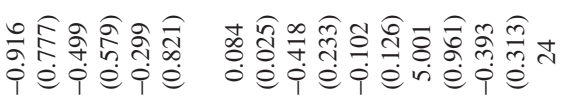

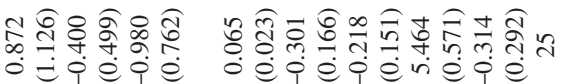

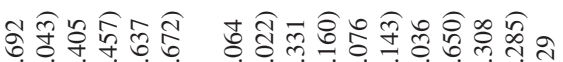

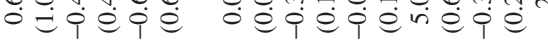

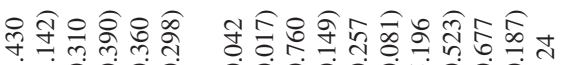
i ¿o仓

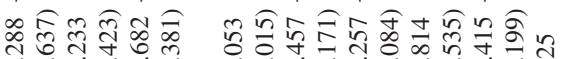

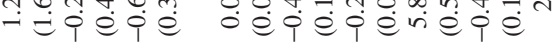

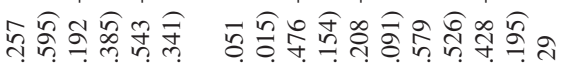

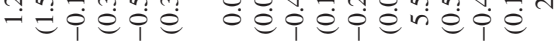

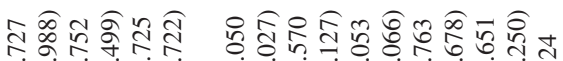

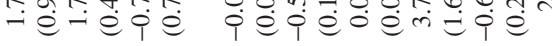

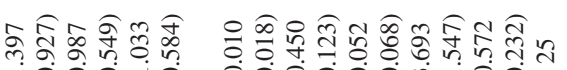

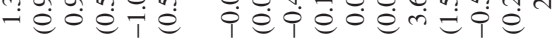

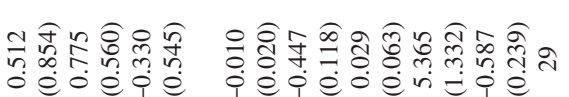
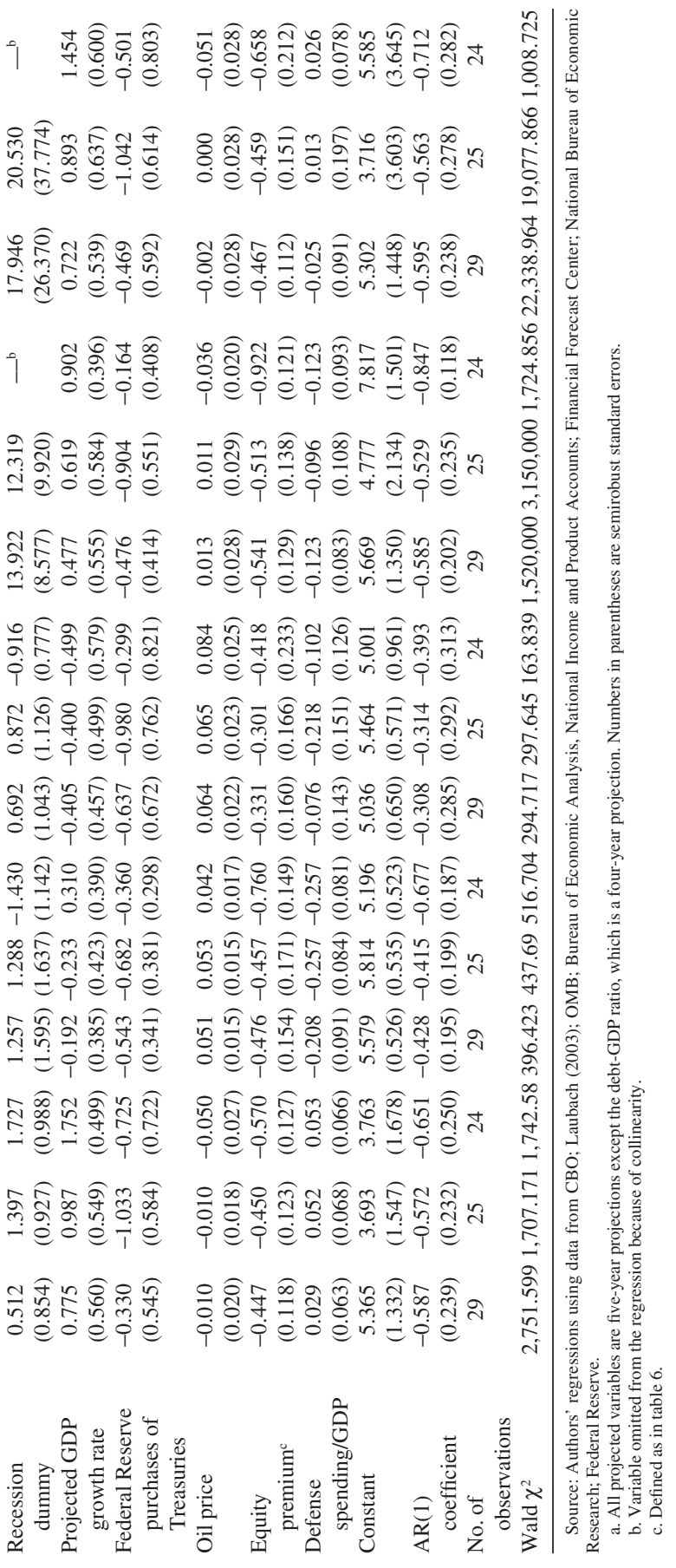
The rest of table 15 addresses the second question. Columns 15-4 through 15-6 replace the projected fiscal policy controls with the current unified deficit, and columns 15-7 through 15-9 do the same using the current standardized deficit. These regressions show positive and significant effects of current deficits on forward long-term rates, with effects ranging between 30 and 45 basis points for a 1-percent-of-GDP change in the current deficit. These effects are almost as large as the effects of projected fiscal policy shown in columns 15-1 through 15-3, and they highlight the concern raised by House that current deficits may be driving the results that have been attributed to projected fiscal policy.

Columns 15-10 through 15-15 include both projected and current deficits. Column 15-12 shows that, for 1981-2004, the period highlighted by House, current deficits have a substantial effect on forward rates41 basis points per percentage point of GDP_-even when projected deficits are controlled for. This is an interesting and unexpected result, but it should not detract from the finding that the impact of projected primary deficits on forward rates is still substantial: 48 basis points per percentage point of GDP, compared with 53 basis points in column 15-1. Thus table 15 shows that, even though current deficits and the five-year-ahead projection of deficits move largely in tandem during the 1981-2004 period, projected deficits still have a large and independent effect on forward long-term rates, even after controlling for current deficits. This in turn implies that the results in tables 6 through 9, linking projected fiscal policy and long-term forward rates, are in no way an artifact of the tight relationship between current deficits and the projected five-year-ahead deficit between 1981 and 2004, nor are projected deficits merely a proxy for current deficits. ${ }^{156}$

Table 16 shows that the heightened sensitivity of interest rates to both current and projected deficits in the 1981-2004 period also holds in regressions that examine the effects of projected fiscal policy on current long-

156. Other results in table 15 are also of interest. When we control for projected deficits, a 1-percent-of-GDP increase in the current deficit raises forward long-term rates by about 20 basis points in the 1976-2004 or the 1976-2000 period (columns 15-10 and 15-11, respectively). A 1-percent-of-GDP increase in the projected primary deficit in year $t+5$ raises forward rates by about 30 basis points. Columns 15-13 through 15-15 control for the current standardized deficit instead of the current unified deficit. In stark contrast to columns 15-7 through 15-9, the current standardized deficit appears to have no effect on forward longterm interest rates across any of the time periods, once projected deficits are included. Controlling for the standardized deficit raises the estimated impact of the projected primary deficit by 10 to 15 basis points, compared with the results that control for the current unified deficit. 
Table 16. ARMA Estimates of the Effects of Projected and Current-Period Fiscal Variables on Real Current Ten-Year Treasury Rates ${ }^{\mathrm{a}}$

\begin{tabular}{|c|c|c|c|c|c|c|}
\hline \multirow[b]{3}{*}{ Independent variable } & \multicolumn{6}{|c|}{ Regression and sample period } \\
\hline & $16-1$ & $16-2$ & $16-3$ & $16-4$ & $16-5$ & $16-6$ \\
\hline & $\begin{array}{c}1976- \\
2004\end{array}$ & $\begin{array}{c}1976- \\
2000\end{array}$ & $\begin{array}{c}1981- \\
2004\end{array}$ & $\begin{array}{c}1976- \\
2004\end{array}$ & $\begin{array}{c}1976- \\
2000\end{array}$ & $\begin{array}{c}1981- \\
2004\end{array}$ \\
\hline \multicolumn{7}{|l|}{ Fiscal variables } \\
\hline Projected debt/GDP & $\begin{array}{c}0.028 \\
(0.035)\end{array}$ & $\begin{array}{c}0.004 \\
(0.029)\end{array}$ & $\begin{array}{r}-0.024 \\
(0.015)\end{array}$ & & & \\
\hline $\begin{array}{l}\text { Projected primary } \\
\text { deficit/GDP }\end{array}$ & $\begin{array}{c}0.096 \\
(0.152)\end{array}$ & $\begin{array}{c}0.226 \\
(0.125)\end{array}$ & $\begin{array}{c}0.764 \\
(0.121)\end{array}$ & & & \\
\hline Current-period debt/GDP & & & & $\begin{array}{c}0.001 \\
(0.091)\end{array}$ & $\begin{array}{r}-0.034 \\
(0.049)\end{array}$ & $\begin{array}{r}-0.003 \\
(0.027)\end{array}$ \\
\hline $\begin{array}{l}\text { Current-period primary } \\
\text { deficit/GDP }\end{array}$ & & & & $\begin{array}{l}-0.019 \\
(0.215)\end{array}$ & $\begin{array}{c}0.127 \\
(0.194)\end{array}$ & $\begin{array}{c}0.336 \\
(0.155)\end{array}$ \\
\hline \multicolumn{7}{|l|}{$\begin{array}{l}\text { Recession dummy } \\
\text { and interactions }\end{array}$} \\
\hline Recession dummy & $\begin{array}{c}4.360 \\
(1.117)\end{array}$ & $\begin{array}{c}3.330 \\
(1.178)\end{array}$ & $\begin{array}{c}6.966 \\
(0.877)\end{array}$ & $\begin{array}{c}3.677 \\
(1.456)\end{array}$ & $\begin{array}{c}1.967 \\
(1.468)\end{array}$ & $\begin{array}{c}3.811 \\
(1.202)\end{array}$ \\
\hline $\begin{array}{l}\text { Recession dummy } \times \\
\text { projected debt/GDP }\end{array}$ & $\begin{array}{c}-0.083 \\
(0.028)\end{array}$ & $\begin{array}{l}-0.060 \\
(0.025)\end{array}$ & $\begin{array}{l}-0.120 \\
(0.017)\end{array}$ & & & \\
\hline $\begin{array}{l}\text { Recession dummy } \times \\
\text { projected primary } \\
\text { deficit/GDP }\end{array}$ & $\begin{array}{c}0.311 \\
(0.145)\end{array}$ & $\begin{array}{c}0.173 \\
(0.122)\end{array}$ & $\begin{array}{l}-0.097 \\
(0.077)\end{array}$ & & & \\
\hline $\begin{array}{l}\text { Recession dummy } \times \\
\text { current-period } \\
\text { debt/GDP }\end{array}$ & & & & $\begin{array}{l}-0.119 \\
(0.046)\end{array}$ & $\begin{array}{c}-0.074 \\
(0.039)\end{array}$ & $\begin{array}{c}-0.111 \\
(0.028)\end{array}$ \\
\hline $\begin{array}{l}\text { Recession dummy } \times \\
\text { current-period primary } \\
\text { deficit/GDP }\end{array}$ & & & & $\begin{array}{c}1.308 \\
(1.262)\end{array}$ & $\begin{array}{c}0.772 \\
(0.943)\end{array}$ & $\begin{array}{c}0.911 \\
(0.440)\end{array}$ \\
\hline $\begin{array}{l}\text { Projected GDP } \\
\text { growth rate }\end{array}$ & $\begin{array}{c}0.982 \\
(1.080)\end{array}$ & $\begin{array}{c}0.765 \\
(0.887)\end{array}$ & $\begin{array}{c}2.137 \\
(0.403)\end{array}$ & & & \\
\hline Current GDP growth rate & & & & $\begin{array}{c}0.025 \\
(0.170)\end{array}$ & $\begin{array}{c}-0.112 \\
(0.170)\end{array}$ & $\begin{array}{c}0.055 \\
(0.077)\end{array}$ \\
\hline $\begin{array}{l}\text { Federal Reserve purchases } \\
\text { of Treasuries }\end{array}$ & $\begin{array}{l}-2.815 \\
(1.547)\end{array}$ & $\begin{array}{l}-2.487 \\
(0.904)\end{array}$ & $\begin{array}{l}-2.694 \\
(0.494)\end{array}$ & $\begin{array}{c}-1.638 \\
(1.389)\end{array}$ & $\begin{array}{l}-1.565 \\
(0.808)\end{array}$ & $\begin{array}{r}-1.808 \\
(0.666)\end{array}$ \\
\hline Control variables & & & & & & \\
\hline Oil price & $\begin{array}{c}0.019 \\
(0.034)\end{array}$ & $\begin{array}{c}0.023 \\
(0.032)\end{array}$ & $\begin{array}{c}-0.090 \\
(0.026)\end{array}$ & $\begin{array}{c}0.043 \\
(0.052)\end{array}$ & $\begin{array}{c}0.046 \\
(0.034)\end{array}$ & $\begin{array}{c}0.036 \\
(0.020)\end{array}$ \\
\hline Equity premium ${ }^{\mathrm{b}}$ & $\begin{array}{c}-0.540 \\
(0.163)\end{array}$ & $\begin{array}{c}-0.506 \\
(0.158)\end{array}$ & $\begin{array}{c}-1.005 \\
(0.098)\end{array}$ & $\begin{array}{c}-0.468 \\
(0.471)\end{array}$ & $\begin{array}{c}-0.601 \\
(0.260)\end{array}$ & $\begin{array}{c}-1.121 \\
(0.223)\end{array}$ \\
\hline Defense spending/GDP & $\begin{array}{c}0.169 \\
(0.188)\end{array}$ & $\begin{array}{c}0.071 \\
(0.170)\end{array}$ & $\begin{array}{c}0.334 \\
(0.076)\end{array}$ & $\begin{array}{c}0.398 \\
(0.355)\end{array}$ & $\begin{array}{c}0.071 \\
(0.317)\end{array}$ & $\begin{array}{c}0.263 \\
(0.126)\end{array}$ \\
\hline Constant & 1.507 & 3.451 & 4.785 & 2.760 & 6.658 & 5.660 \\
\hline
\end{tabular}


Table 16. ARMA Estimates of the Effects of Projected and Current-Period Fiscal Variables on Real Current Ten-Year Treasury Rates ${ }^{\text {(continued) }}$

\begin{tabular}{lcccccc}
\hline & \multicolumn{6}{c}{ Regression and sample period } \\
\cline { 2 - 7 } & $16-1$ & $16-2$ & $16-3$ & $16-4$ & $16-5$ & $16-6$ \\
\cline { 2 - 7 } & $1976-$ & $1976-$ & $1981-$ & $1976-$ & $1976-$ & $1981-$ \\
Independent variable & 2004 & 2000 & 2004 & 2004 & 2000 & 2004 \\
\hline & $(2.371)$ & $(2.231)$ & $(0.996)$ & $(5.596)$ & $(3.911)$ & $(1.922)$ \\
AR(1) coefficient & -0.258 & -0.106 & -0.844 & 0.191 & 0.302 & -0.196 \\
& $(0.561)$ & $(0.369)$ & $(0.168)$ & $(0.753)$ & $(0.404)$ & $(0.417)$ \\
No. of observations & 29 & 25 & 24 & 29 & 25 & 24 \\
Wald $\chi^{2}$ & $1,461.312$ & $7,677.126$ & $9,711.773$ & 398.419 & 287.23 & $6,623.901$ \\
\hline
\end{tabular}

Source: Authors' regressions using data from CBO; Laubach (2003); OMB; Bureau of Economic Analysis, National Income and Product Accounts; Financial Forecast Center; National Bureau of Economic Research; Federal Reserve.

a. All projected variables are five-year projections except the debt-GDP ratio, which is a four-year projection. Numbers in parentheses are semirobust standard errors.

b. Defined as in table 6 .

term rates (similar to tables 10 through 12) and the effects of current fiscal policy on current long-term rates (similar to table 13). During the period since 1981, a 1-percent-of-GDP increase in projected deficits raises current long-term rates by 76 basis points, and a 1-percent-of-GDP increase in the current primary deficit raises current long-term rates by 33 basis points. These results imply much stronger effects of projected and current fiscal policy on current interest rates for this shorter period than tables 10 through 13 suggest for the whole 1976-2004 period.

\section{Summary}

In the preferred specifications (tables 8 and 9), which allow both debt and deficits to affect interest rates, the estimated effect on forward longterm rates from a 1-percent-of-GDP shift in projected primary budget variables ranges between 40 and 70 basis points, depending on the specification and on whether the fiscal variable is the primary deficit, or revenue and primary outlays separately. Our effects are larger than those found by Laubach and by Engen and Hubbard, ${ }^{157}$ because we include both projected debt and projected deficits as variables, and because we include measures of whether the economy is currently in recession. The results show that the effects of projected deficits are larger when projected debt is included, and

157. Laubach (2003); Engen and Hubbard (2004). 
that the effect of a given future deficit tends to be larger if the economy is currently not in a recession than if it is.

In sharp contrast, the projected debt-GDP ratio never exerts a positive and significant effect on future interest rates when it is entered in a regression that also includes projected deficits. The projected deficit thus seems a more informative measure than projected debt. This is reflected in table 6 , where the deficit-only equations had significantly higher $R^{2}$ s than the debtonly equations, and most strikingly in tables $8,9,14,15$, and 16 , where, when both variables are entered, deficits have large effects and the debt has virtually none.

Our estimates of the effect of an increase in the projected unified budget deficit are somewhat smaller_- 25 to 35 basis points for each 1-percent-ofGDP increase - than that of an increase in the primary deficit. This should be expected, since a shift of 1 percent of GDP in the primary deficit would represent a more dramatic change than a shift of 1 percent of GDP in the unified deficit. Finally, our results when debt is entered in the equation by itself suggest that an increase in the projected debt by 1 percent of GDP raises long-term rates by between 3 and 6 basis points.

All of the estimates above may understate the true effects for at least two reasons. First, as Rubin, Orszag, and Sinai note, ${ }^{158}$ and as discussed earlier in the paper, the effects would be larger if sustained deficits cause investors to lose confidence in the ability of policymakers to avoid a fiscal crisis. Second, because the projected fiscal policy variables are only approximations of investors' true expectations, the regressions may suffer from classical measurement error, which would bias the coefficient on projected deficits toward zero.

\section{Conclusion}

The empirical evidence presented in this paper indicates that federal budget deficits reduce national saving and raise long-term interest rates. Reasonable rules of thumb based on our estimates are that each 1-percentof-GDP increase in current deficits reduces national saving by 0.5 to 0.8 percent of GDP, that each 1-percent-of-GDP increase in projected future unified deficits raises forward long-term interest rates by 25 to 35 basis points, and that each 1-percent-of-GDP increase in projected

158. Rubin, Orszag, and Sinai (2004). 
future primary deficits raises forward long-term interest rates by 40 to 70 basis points.

These findings carry substantial implications. First, both the consumption and the interest rate results reject the Ricardian view of the world. Second, the interest rate results reject the small open economy view, at least as it applies to the U.S. economy.

Third, the results suggest that the sustained fiscal deficits now facing the United States will impose significant economic costs. Under the assumptions we have described, the unified budget deficit over the next decade is projected to average about 3.5 percent of GDP. Our results suggest that these deficits will reduce annual national saving by 2 to 3 percent of GDP. As a result, by the end of the decade, the assets owned by Americans will be roughly 20 to 30 percent of GDP less than they would be if the unified budget were balanced over the next decade. With a rate of return on capital of 6 percent, those missing assets will reduce national income by 1 to 2 percent in 2015 and each year thereafter. ${ }^{159}$ Our results also suggest that the increase in unified deficits will raise interest rates by 80 to 120 basis points.

Fourth, our results suggest that making the 2001 and 2003 tax cuts permanent would raise the cost of capital for new investment, reduce longterm investment, and reduce long-term economic growth. Tax cuts have offsetting effects on the cost of new investment, with marginal tax rate cuts reducing, and higher interest rates from deficits increasing, the cost of capital. Gale and Samara Potter show that, if the 2001 tax cut were to raise interest rates by 50 basis points, the cost of capital would rise for corporate equipment and structures, noncorporate equipment and structures, and owner-occupied housing. ${ }^{160}$ By 2014 the 2001 tax legislation, if extended past its official sunset, would increase the public debt by just over $\$ 3.4$ trillion, ${ }^{161}$ or about 19 percent of projected GDP in 2014. This implies an interest rate increase of 57 basis points using the Engen and Hubbard estimates, ${ }^{162}$ and an even larger increase using our estimates. From an alternative perspective, making the 2001 tax cut permanent would reduce

159. The assumption of a 6 percent rate of return is intended to be conservative, understating the effects. If, for example, the rate of return were instead 12 percent, as assumed in our benchmark calculation, the loss of national income would be 2 to 4 percent in 2015 and each year thereafter.

160. Gale and Potter (2002).

161. This estimate is based on Joint Committee on Taxation $(2001,2002,2003)$ revenue figures for the original legislation, $\mathrm{CBO}$ estimates of the costs of extensions, and CBO interest rate matrix calculations for debt service costs.

162. Engen and Hubbard (2004). 
revenue by about 1.7 percent of GDP on a permanent basis (assuming the tax cuts are not effectively supplanted by the alternative minimum tax). Using our estimates for primary deficits, this implies that interest rates will rise by 70 and 120 basis points. Both sets of estimates imply that the 2001 tax cut will end up reducing long-term investment. It might be thought that the 2003 tax cut would have more beneficial effects on investment, since it focused on dividend and capital gains tax cuts. In recent work, however, we show that the net effect of making the 2001 and the 2003 tax cuts permanent would be to raise the cost of capital once the interest rate effects are taken into account- even under the Engen-Hubbard estimates. ${ }^{163}$ These findings imply that making the tax cuts permanent would reduce the longterm level of investment, which is consistent with a negative effect on national saving and on future living standards.

Finally, after 2014 the budget outlook grows steadily worse as costs associated with federal retirement and health programs mount. Under reasonable projections and in the absence of policy changes, the nation thus faces a long period of sustained large budget deficits. In this context the negative long-term effects of deficits presented in this paper, substantial though they are, may provide an unduly auspicious perspective on the adverse consequences of fiscal deficits.

163. Gale and Orszag (2004b). 


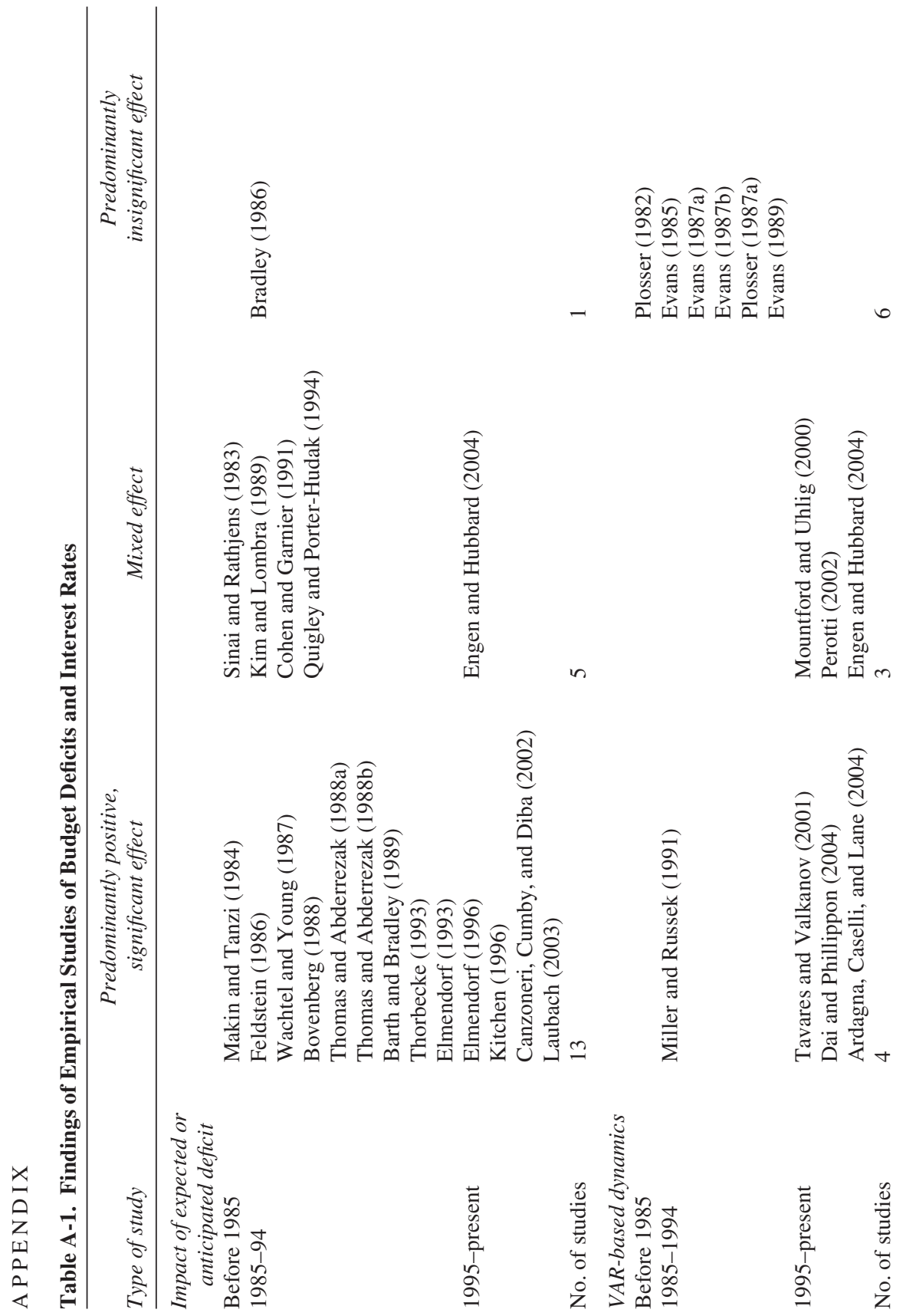


William G. Gale and Peter R. Orszag

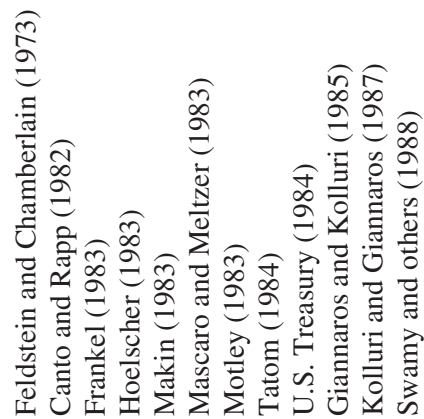

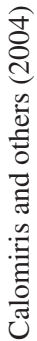
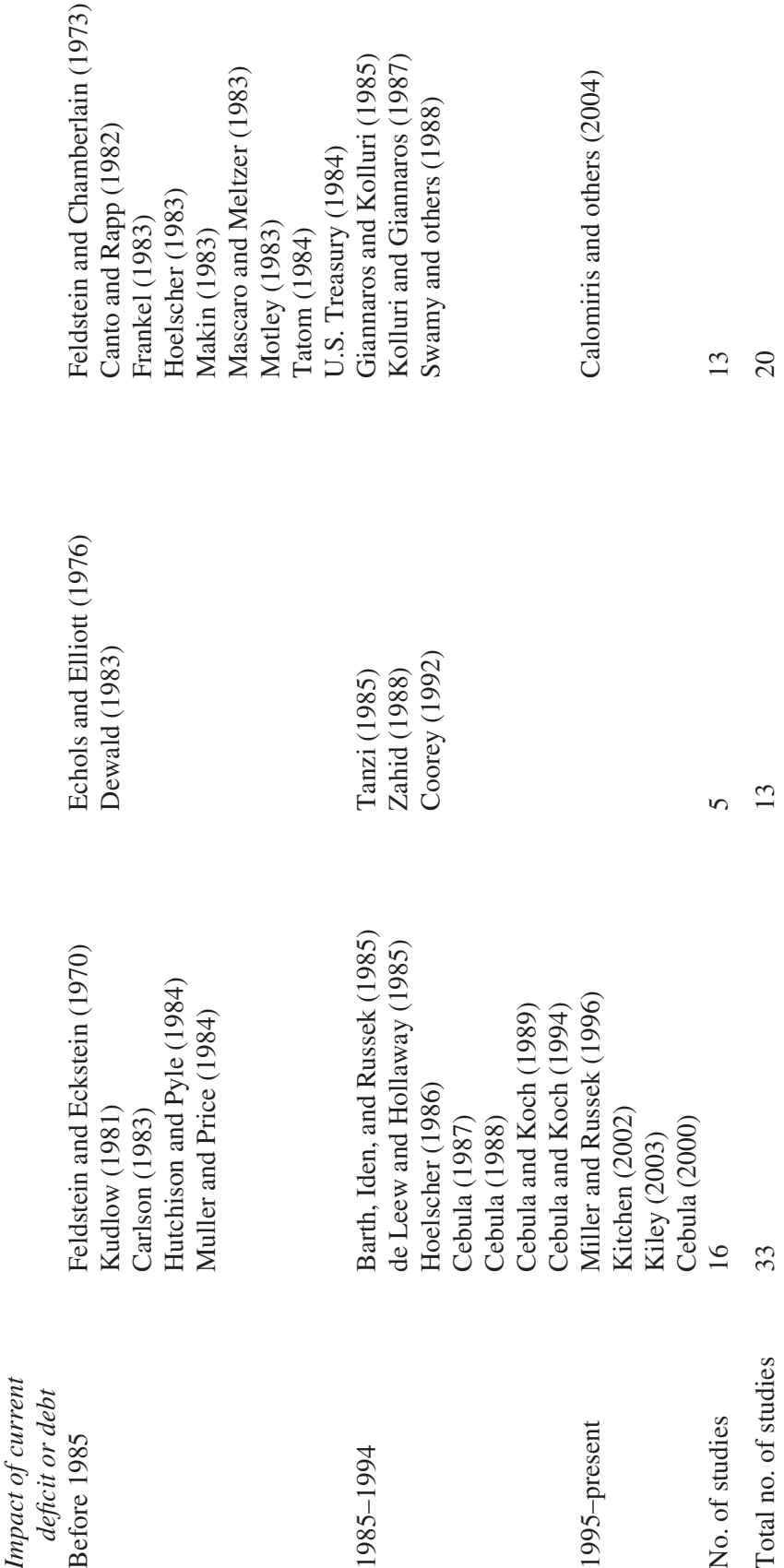

\begin{tabular}{l}
\multirow{2}{2}{} \\
$\frac{1}{1}$ \\
$\infty$ \\
0 \\
2
\end{tabular}

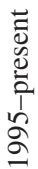

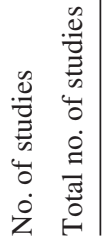




\section{Comments and Discussion}

Eric M. Engen: Government debt and deficits matter. Although some politicians may argue that deficits do not affect the politics of public policy or voters' behavior, government borrowing does affect the economy. The disagreements among economists concerning government debt and deficits are primarily over the channels through which the effects occur and the magnitude of those effects.

In this paper, William Gale and Peter Orszag review past and expected future federal government borrowing and present a theoretical summary of some of the different ways in which government debt can affect the economy. They also contribute to the body of research on the economic effects of government debt by providing new empirical estimates of two channels through which these effects operate. First, they estimate the degree to which private domestic saving may rise coincidently with increased government borrowing. Second, they estimate the effect of federal government debt and deficits on interest rates. My discussion will focus first on their empirical analyses of the two channels and then turn to their more general discussion of the economic effects of government debt.

The first part of the authors' empirical analysis estimates both an aggregate consumption function and an Euler equation specification for changes in aggregate household consumption spending. In both specifications they estimate the impact of changes in debt-financed government taxes while controlling for government spending, (lagged) government debt, marginal tax rates on capital and labor, and other economic factors. This empirical analysis contributes to the literature that studies whether households are more Keynesian or more Ricardian in their reactions to government borrowing, 
that is, whether households view government bonds issued because of a tax cut as net wealth or as future tax obligations.

The authors' results, using several different empirical specifications, imply that households are neither purely Keynesian nor purely Ricardian. In most of their regressions they find that, in the short run, a statistically significant portion of a debt-financed tax cut is saved, but their estimates of that response cover a fairly broad range. In their aggregate consumption function specifications, with federal spending held constant, a one-dollar decrease in federal tax payments is estimated to increase consumption spending in the short run by 30 to 46 cents, implying that households offset 54 to 70 percent of the increase in federal borrowing by saving more. The Euler equation estimates yield a much broader range of results, which depend crucially on whether changes in consumption are measured in levels or as a ratio to net national product, whether controls for marginal tax rates are included, and whether explanatory variables are treated as endogenous. In these estimates, with federal spending held constant, a one-dollar decrease in federal tax payments is estimated to increase consumption spending in the short run in the range of 22 to 98 cents, implying that household saving offsets anywhere from 2 to 78 percent of the increase in federal borrowing.

Although Gale and Orszag state that their preferred estimates suggest that increases in private saving offset a much narrower 20 to 50 percent of the increase in federal borrowing from a tax cut, it is difficult a priori to rule out any of their specifications, and readers may have their own preferences. ${ }^{1}$ Despite the authors' improvements over many previous econometric analyses of this issue, their broad range of estimates provides little assurance that this analysis advances the consensus on the short-run magnitude of this effect, even if we can safely rule out that households do not

1. Recent analysis of the deficit-financed tax rebates in 2001 by Johnson, Parker, and Souleles (2004) using household-level spending data suggests that about 50 to 70 percent of these tax rebates were spent, on average, in the following two quarters. The results of this short-run, household-level analysis of the 2001 tax rebate are consistent with the authors' preferred range of estimates from their aggregate spending analysis. However, this deficitfinanced tax cut was implemented during a recession, and so it is not clear whether the results of this study are more generally comparable to the effect of deficit-financed tax cuts in the many nonrecession periods covered by Gale and Orszag's aggregate data. Shapiro and Slemrod (2003) also investigate the effects of the 2001 tax rebate, and, although they do not use the more detailed household-level spending data used in Johnson, Parker, and Souleles (2004), they find qualitatively similar results. 
appear to be purely Keynesian or purely Ricardian. Moreover, as the authors note in discussing their results, these estimates do not address the potential long-run effect of deficit-financed tax cuts on private saving, which could differ from the short-run effect.

The second part of Gale and Orszag's empirical analysis investigates the effects of federal government debt and deficits on interest rates. Their empirical research here is similar to recent studies by Thomas Laubach and by Glenn Hubbard and myself. ${ }^{2}$ In general, their estimates of the effect of the federal debt or deficit on the level of the real interest rate are fairly similar to what these other recent studies find. Although the specifications vary to some degree from paper to paper, all three find that a 1-percentage-point increase in the Congressional Budget Office's five-year-ahead projection of federal debt relative to GDP increases the real five-year-ahead ten-year Treasury rate by about 2 to 5 basis points. All three studies estimate that a 1-percentage-point increase in the CBO's five-year-ahead projection of the federal deficit relative to GDP increases the real five-year-ahead ten-year Treasury rate in a somewhat broader range, from 25 to 38 basis points. The relative similarity of the results across these three papers stands in marked contrast to the incredibly wide range of empirical estimates reported in the earlier literature.

Where the papers part company, however, is over which specificationone that regresses the level of the interest rate on the level of federal debt, or one that regresses it on the change in federal debt (that is, the level of the deficit) - is potentially more informative and more consistent with the current state of macroeconomic analysis of this issue. Gale and Orszag believe that the specification using the deficit is more informative. They suggest that, if the change in the deficit is perceived by financial markets as essentially permanent, or at least persistent, then the deficit specification better captures the effects of this perception. Gale and Orszag basically interpret these results in a manner consistent with Laubach's reconciliation of the differences between the debt-based and the deficit-based approach. Hubbard and I, in contrast, view the former (that is, the specification relating the level of federal debt to the level of the interest rate) as both more informative and more consistent with the current state of macroeconomic theory. Moreover, we offer a different explanation for reconciling the different empirical results.

2. Laubach (2003); Engen and Hubbard (2004). 
The specification used most often in previous studies of this issue has been one that regresses the level of the interest rate on the deficit. This specification comes from the relationship implied by a Keynesian IS-LM framework. However, as Gregory Mankiw wrote in his review of the state of macroeconomics over a decade ago, "The IS-LM model rarely finds its way into scholarly journals: some economists view the model as a relic of a bygone age and no longer bother to teach it. The large-scale macroeconometric models are mentioned only occasionally at academic conferences, often with derision." ${ }^{3}$ Instead intertemporal models based on a production function in which the interest rate is ultimately determined by the level of the capital stock, and thus by the level of federal debt, are much more conventional in current macroeconomic analysis. ${ }^{4}$ Examples include the Solow growth model, the Ramsey-Cass-Koopmans model, and the Diamond model as discussed in David Romer's graduate macroeconomics text; ${ }^{5}$ the overlapping-generations models presented in Olivier Blanchard and Stanley Fischer's macroeconomics text; ${ }^{6}$ and the general equilibrium model used in the widely cited book on fiscal policy by Alan Auerbach and Laurence Kotlikoff. ${ }^{7}$ In all of these types of macroeconomic models, the interest rate is determined by the marginal product of capital and is a function of the level of the capital stock, which in turn is determined by federal government debt rather than just the deficit. Thus Hubbard and I suggest that the econometric specification that relates the level of government debt to the level of the interest rate is more consistent with the current state of macroeconomic theory than one that relates the level of the deficit to the level of the interest rate. ${ }^{8}$

Gale and Orszag as well as Laubach suggest that the specification using the deficit is still informative if changes in the federal deficit are perceived by financial market participants to be very persistent. Indeed, if so, this could help explain the larger interest rate effect estimated when the deficit is used. However, if projected deficits are persistent, this information should also be reflected in a measure of projected federal debt, which

3. Mankiw (1990, p. 1646).

4. Engen and Hubbard (2004) discuss such a model. This is the case even if other features of the model yield more Keynesian, rather than classical, results. See Mankiw (1992).

5. Romer (1996).

6. Blanchard and Fischer (1989).

7. Auerbach and Kotlikoff (1987).

8. Engen and Hubbard (2004). 
includes not only the deficit projection for a particular year but also projections for earlier years.

An alternative explanation for this difference in the estimated interest rate effects is suggested in my paper with Hubbard. Because the Congressional Budget Office's projections of federal deficits are closely correlated with their projections of federal debt (the correlation coefficient is .89 with both projections expressed as a percentage of GDP), the coefficient estimate on the smaller deficit component also picks up the effect of previously accumulated government debt, and the coefficient estimate is larger than when total government debt is used. Thus the larger interest rate effect estimated using the deficit specification may reflect not the implied persistence of deficit projections by financial market participants, but rather a misspecified model.

Gale and Orszag's discussion of the potential effects of government borrowing makes many other interesting and thoughtful points concerning government debt that are beyond the scope of my comments here. However, I will conclude with two related points about the overall picture for future fiscal policy and federal borrowing in the United States that the paper does not emphasize. First, much of the emphasis in this paper on these future developments focuses on the recent tax cuts. However, future government borrowing will in all likelihood be determined more by what happens with spending on Social Security, Medicare, and Medicaid. Moreover, the history of federal tax policy in the United States shows that whereas legislation to adjust taxes is passed frequently, and that tax increases are not uncommon, entitlement reform occurs far less frequently. Particularly rare are changes in entitlements that reduce rather than increase their projected growth.

Second, federal borrowing is not the only feature of fiscal policy that has macroeconomic impacts. Both the level and the structure of government taxes and spending can also have significant effects. If the fiscal gap is closed in the years ahead by raising taxes, particularly taxes on labor and capital, the negative effect on the economy will likely be much greater than if the fiscal gap were closed by reforming entitlement spending. The type and mix of policies ultimately used to reduce the fiscal gap are at least as important as reducing the expected future government borrowing associated with current fiscal policy. 
Christopher L. House: How do budget deficits affect the economy? This is the central question in this paper by William Gale and Peter Orszag, and, not surprisingly, it is a difficult question to answer. Moreover, since the deficit is simply spending minus revenue, the answer to this question seems to require answers to two other questions: How do taxes affect the economy? And how does government spending affect the economy? To isolate the effects of deficits, Gale and Orszag cast their question in terms of Ricardian equivalence.

Ricardian equivalence says that, if the government cuts taxes today but commits itself to increase future taxes by an amount equal to the capitalized value of the tax cut, there should be no effect on economic activity. A tax change that has no effect on the present discounted value of taxes- that is, a policy that changes only the timing of tax collection-is very special. Here I will refer to such a tax cut as a Ricardian tax cut. Ricardian tax cuts are the only tax cuts that leave a consumer's permanent income unchanged, and thus a deficit caused by a Ricardian tax cut has no effect on the economy. Of course, Ricardian equivalence holds only under certain conditions: consumers must be rational and forward looking, they must have access to loan markets, taxes cannot be distortionary, and so on. However, the basic message of Ricardian equivalence is clear: there is no direct connection between deficits and economic activity.

To assess whether Ricardian equivalence is a good approximation for policy analysis in the real world, Gale and Orszag examine two statistical relationships: the reaction of aggregate consumption to tax changes, and the relationship between deficits and interest rates. Ricardian equivalence says that neither consumption nor the real interest rate should respond to deficits caused by a Ricardian tax cut.

To examine the relationship between aggregate consumption and budget deficits, Gale and Orszag estimate a consumption function of the form

$$
\Delta C_{t}=\beta_{0}+\beta_{1} \Delta Y_{t}+\beta_{2} \Delta T_{t}+\beta_{3} \Delta G_{t}+\ldots+e_{t},
$$

where $\Delta$ is the difference operator $\left(\Delta x=x_{t}-x_{t-1}\right)$. Because they include government spending $\Delta G_{t}$ in the regression, the coefficient on government revenue $\Delta T_{t}$ gives the partial correlation between government surpluses and consumption. They find that the coefficient on $\Delta T_{t}$ is negative and statistically significant. An increase in taxes of 1 percent of GDP is associated with a reduction in consumption of between 0.5 and 0.8 percent of GDP. The systematic reaction of consumption to variations in taxes, controlling 
for government spending, appears to be prima facie evidence against the Ricardian view.

There are two challenges to a causal interpretation of regression estimates of equation 1 , however. The first is that Ricardian equivalence applies only to Ricardian tax cuts. Tax changes that affect permanent income will typically cause changes in consumption when they occur. In other words, even if the world were Ricardian, there would be no reason to expect the coefficient on $\Delta T_{t}$ to be zero.

The second problem, not wholly unrelated to the first, is that the righthand-side variables are endogenous. Omitted variables that are correlated with both $\Delta T_{t}$ and $\Delta C_{t}$ (and thus in the error) may cause the estimated coefficients to be biased from their true structural values.

It is instructive to consider an idealized environment in which equation 1 flows directly from maximizing behavior and in which Ricardian equivalence is known to hold. For specificity, suppose that in each period a consumer maximizes lifetime utility $\sum_{t=0}^{\infty} \beta^{t} u\left(C_{t}\right)$ subject to a budget constraint

$$
C_{t}+\left[A_{t+1} /(1+r)\right]=Y_{t}-T_{t}+A_{t},
$$

where $A$ denotes the consumer's current real assets. Income $(Y)$ and taxes $(T)$ are uncertain but depend on a set of forecasting variables $\mathbf{X}_{t}$, which could include lagged values of $Y, T$, and so forth. The solution to this optimization problem is a state-dependent consumption function $C=c(Y, T, \mathbf{X}, A)$. That $C$ depends on $Y, T$, and $A$ is not surprising. Because it forecasts future levels of after-tax income, $\mathbf{X}$ also influences $C$.

Although the precise form of the consumption function depends on the form of the utility function, the stochastic process for income and so forth, we can approximate it to obtain a linear equation similar to equation 1 :

$$
\Delta C_{t}=c_{0}+c_{y} \Delta Y_{t}+c_{T} \Delta T_{t}+c_{x} \Delta \mathbf{X}_{t}+c_{a} \Delta A_{t} .
$$

If this consumer is a representative consumer, this is the aggregate consumption function, $c_{y}$ is the aggregate marginal propensity to consume (MPC) out of current income $Y$, and $c_{T}$, the coefficient that Gale and Orszag focus on, is the aggregate MPC from a tax cut. The standard Keynesian assumption is that $c_{y}$ is between zero and 1 and that $c_{T}=-c_{y}$.

Ricardian equivalence holds in this setting. Faced with a Ricardian tax cut, the consumer will not alter his or her consumption spending at all. Importantly, however, this does not imply that $c_{T}$ is zero. In fact, it is almost 
certainly not zero. Only if all tax changes were Ricardian would $c_{T}=0$. Any change in taxes that signals a permanent change in after-tax income would cause the consumer to rationally alter his or her spending.

In reality, many tax changes have this property. For instance, consumption should react to a "peace dividend" like that at the end of the cold war. Such a tax change is associated with projected reductions in future government spending and thus might have an effect on the consumer's permanent income. Tax cuts intended to "starve the beast"- that is, that reduce revenue in order to force reductions in spending — might also be perceived to have a permanent impact on the consumer's after-tax income. The tax cuts of 2001 and 2003 are intended to be permanent. Even if they are not, there is no implicit or explicit plan to recover the forgone revenue with higher future taxes. If people believe that the budget will be balanced in part through spending cuts, consumption should increase.

In general, the sign of $c_{T}$ depends not on whether Ricardian equivalence holds, but rather on the relationship between current tax changes and future tax changes. If current tax changes always come with the assurance of offsetting future tax changes (that is, if the projected path of government spending is unchanged) then $c_{T}=0$. Otherwise $c_{T} \neq 0$. In particular, $c_{T}<0$ is entirely consistent with Ricardian behavior. At a basic level, the problem is whether the regression adequately controls for future changes in government spending. Although equation 1 includes current and lagged government purchases, it is not clear whether this is enough to test Ricardian equivalence.

The second issue with the estimation of equation 1 is the endogeneity problem. Unless all of the relevant $\mathbf{X}$ variables are included in the regression, it is likely that the OLS coefficients will be biased. If all of the relevant variables in $\mathbf{X}$ were known, the estimated equation would fit perfectly and the correct structural parameters could be estimated.

To deal with the endogeneity problem, Gale and Orszag use an instrumental variables procedure that builds on the approach taken by Robert Hall and by John Campbell and Gregory Mankiw. ${ }^{1}$ Campbell and Mankiw's procedure takes advantage of the fact that, under fairly general conditions, the permanent income hypothesis (PIH) implies that the change in consumption from one period to the next is uncorrelated with past information. Put differently, consumption does not respond to anticipated changes in dispos- 
able income. Thus, for consumers who obey the PIH (Ricardian consumers), any lagged variable that is correlated with current taxes is a valid instrument.

The basic approach considers an environment with both forwardlooking (Ricardian) consumers and "rule-of-thumb" consumers. ${ }^{2}$ The forward-looking consumers behave according to the PIH, whereas the rule-of-thumb consumers are assumed to simply consume their disposable income $(c=y-T)$. If $\lambda$ is the fraction of rule-of-thumb consumers, it is easy to show that aggregate consumption obeys

$$
\Delta C_{t}=\lambda\left[\Delta Y_{t}-\Delta T_{t}\right]+v_{t},
$$

where $\operatorname{Cov}\left(Z_{t-1}, v_{t}\right)=0$ for any lagged variable $Z_{t-1}$. Thus any $Z_{t-1}$ is potentially a valid instrument. The identification problem from this approach is quite subtle, however. Although lagged variables are valid instruments, they do not identify the aggregate MPC. Instead they identify $\lambda$, the fraction of non-Ricardian agents. The aggregate MPC out of taxes is the sum of the MPC for the Ricardian agents (what I called $c_{T}$ above) and the MPC for the rule-of-thumb consumers, which is 1 by assumption. The aggregate MPC, which is what Gale and Orszag care about, is then

$$
\mathrm{MPC}=(1-\lambda) c_{T}+\lambda .
$$

Thus $\lambda$ is equal to the aggregate MPC only if $c_{T}=0$, which brings us back to the first point: even if Ricardian equivalence holds, the MPC out of taxes is not generally zero; only if all tax changes were Ricardian would $c_{T}=0$.

A natural question then arises as to whether one can use lagged variables as instruments for a model with only Ricardian (that is, PIH) consumers. Unfortunately, the answer to this question is no. Although these are valid instruments, they are not useful. The PIH says that $E_{t}\left(\Delta C_{t+1}\right)=0$ and that $\operatorname{Cov}\left(\Delta C_{t+1}, Z_{t}\right)=0$. If an instrumental variables regression of the change in consumption on the change in income yields a nonzero coefficient, the PIH can be rejected. Unfortunately, the validity of the instruments must also be rejected, since they rely directly on the PIH being true.

Empirically addressing whether the economy is Ricardian appears to require a special instrument-specifically, it requires an instrument for a Ricardian tax cut. Put differently, to know how consumers respond to changes in the timing of taxes, one must observe their reaction to such policies.

2. In addition to the rule-of-thumb consumers considered by Campbell and Mankiw, Gale and Orszag include "life cycle" consumers, following Blanchard (1985). 
The second type of evidence that Gale and Orszag examine is the statistical correlation between real interest rates and budget deficits. They make no claim that their results are causal or structural; rather they confine themselves to investigating whether a strong statistical relationship exists between deficits and interest rates. To answer this question they consider a variety of regressions of real interest rates on measures of the deficit as a percentage of GDP. The regressions include cyclical indicators and other covariates.

Their main finding is that one gets very different answers depending on whether real interest rates are regressed on current deficits or on expected future deficits. They find that expected future deficits have a strong positive correlation with real interest rates, whereas current actual deficits do not. Although the partial correlation between current deficits and real interest rates is positive, it is typically not statistically significant. This finding has intuitive appeal. Interest rates are inherently forward looking and, as a result, undoubtedly incorporate expectations about future pressures in the lending market. This explanation is particularly appealing if the deficit forecasts contain significant information beyond the simple correlation of deficits at time $t$ with deficits at time $t+k$.

The interpretation that the authors' finding is due to the forward-looking nature of interest rates is quite plausible. Moreover, several alternative explanations can be ruled out. For instance, since high current interest rates would increase future interest payments, one might expect that reverse causality could lead to such a finding. Gale and Orszag show, however, that their finding remains intact if they use the primary deficit instead (that is, if they exclude debt service). Another possibility is that the CBO's budget forecasts are systematically optimistic, and thus a projected future deficit is indicative of a much larger current deficit. A simple examination of the dynamic relationship between current and future deficits reveals that, although this effect may be present to some extent, it cannot explain the authors' results.

There are two reasons to doubt the "forward looking" interpretation. First, from a purely numerical point of view, the main difference between current deficits and projected deficits, and thus the main difference between the two regression results, comes from only a handful of observations. Projected deficits and current actual deficits track each other closely for most of the sample period. However, early in the sample (from 1976 to 1981), there are a few sharp differences between the CBO's deficit projections and the current deficit. If those observations are dropped from the sample, the 
correlation between current deficits and real interest rates is comparable to the correlation between projected deficits and real interest rates.

Second, an essential component of the "forward looking" interpretation is the notion that $\mathrm{CBO}$ forecasts are informative about future budget deficits. Surprisingly, the sample correlation between projected deficits and actual realized future deficits is negative. Put differently, one might do better by guessing the opposite of the $\mathrm{CBO}$ forecast. It is important not to overstate this negative correlation, however. Like the contemporaneous correlation between projected deficits and current deficits, much of the negative correlation comes from only a few observations.

Neither of these observations invalidates Gale and Orszag's basic finding, but both suggest that the interpretation of the correlation must be made with care. In the end, Gale and Orszag have only a limited amount of data on which to base their conclusion. Whether their finding is due to the fact that interest rates are forward looking and thus anticipate expected future borrowing is ultimately not clear.

It should be emphasized that, even if the world were Ricardian, there would still be good reasons to be concerned about deficits. Properly managed budget deficits increase the efficiency of the economy by smoothing distortionary tax rates over time. ${ }^{3}$ The government should borrow when spending is above average or revenue is below average. When spending is low or revenue is high, the government should save. If, however, because of poor planning or a lack of political willpower, the government does the opposite, it will find itself in the undesirable position of having to raise taxes dramatically just when it most needs the revenue.

In a non-Ricardian world, the inefficiencies associated with poorly managed government debt are magnified. In addition to suffering inefficient variations in distortionary tax rates, firms may be forced to abandon economically viable investment projects so that the government's spending can be financed.

On the whole, although it is far from conclusive, the evidence presented by Gale and Orszag casts doubt on the Ricardian view of government budget debt and deficits. Taken literally, the paper says that an increase in deficit financing of 1 percent of GDP reduces national saving by roughly half of a percent of GDP and raises interest rates by roughly 30 basis points. Eco-

3. Barro (1979). 
nomically, these are very substantial effects. If Gale and Orszag are correct, we should indeed be worried about the current path of the federal budget.

General discussion: Benjamin Friedman emphasized that the authors' coefficient estimates relating the real interest rate to the debt-GDP ratio might appear to be small but in fact implied substantial effects of deficits on capital formation. He reminded the Panel that fiscal policy during the Reagan administration raised the debt-GDP ratio by approximately 25 percentage points, which, given the paper's estimates, corresponds to a 75-basis-point increase in real interest rates. Such an increase would be quite large both by historical standards and compared with the curvature of the production function. If, in equilibrium, the real marginal product of capital corresponds to the real interest rate, then the former will also be increased by 75 basis points, which would require a very large reduction in capital intensity unless the elasticity of substitution is much smaller than usually assumed. Friedman also pointed out that the latest CBO baseline projection of future deficits, which implies only a small increase in the debt-GDP ratio and thus a small impact on real interest rates, is misleading. After making the authors' adjustments to the $\mathrm{CBO}$ baseline projection, the implied future debt-GDP ratio is much larger, and the estimated impact on real interest rates is substantial. Referring to Christopher House's comment on the paper, Friedman pointed out that there is no practical difference between, on the one hand, a world where tax cuts will be undone as assumed in the Ricardian model but the behavior of consumers is not Ricardian and, on the other, a world where behavior is Ricardian but the tax cuts are not undone. Therefore, when one is thinking about the effects of actual U.S. fiscal policy, this distinction is unimportant.

Some panelists questioned whether the results reported in the paper should be expected to hold during periods of fiscal stress. Lars Svensson noted that Ricardian equivalence would not normally hold, but he cited the Swedish example of the early 1990s, when consumption dropped and saving increased dramatically in the face of a large fiscal deficit. He reasoned that people then viewed the fiscal situation as unsustainable and, fearing that it would soon lead to a reduction of benefits or an increase in taxes, started saving for that rainy day. Under such circumstances, Ricardian equivalence may be more likely. Austan Goolsbee argued that the effect of the fiscal position on interest rates would not be linear in a crisis and so could not be inferred from the authors' estimates. The experience of coun- 
tries that have fallen into fiscal crisis shows that there is little effect on interest rates until the sustainability of the debt comes into question, at which point interest rates increase dramatically. He thought it was important to understand why the large debts and deficits in the United States in the 1940s and in Japan in recent years had so little effect on interest rates, and under what circumstances that might change. Goolsbee also pointed out that projections of future deficits make assumptions about several important factors, such as income growth and the rate of return on equities, that are also important to current consumption. He suggested that, rather than use such projections, the effects of future revenue growth be estimated using the tax rates called for in legislation as instruments.

Olivier Blanchard was skeptical of the paper's Euler equation tests of Ricardian equivalence. In the end, such a test involves regressing the change in consumption on the change in income, the change in taxes, and some other factors that usually are not significant. However, the change in taxes is likely to proxy for the change in spending, so that it is hard to interpret its coefficient. For this and other reasons, he found it hard to believe the results of such a test. Blanchard noted that several papers have found effects on consumption from the timing of tax payments, but such results are of limited use if one is interested in the effects of large deficits on the economy over many years. The high correlation between national saving and federal saving that is apparent in the authors' figure 6 does not imply causality, because so many factors affect both public and private saving. However, the relation might be tested using an instrument that, under the assumption of Ricardian equivalence, would not affect national saving except through public saving. Candidates for such an instrument might be fiscal rules such as Gramm-Rudman-type spending caps or a variable identifying the political party in power. 


\section{References}

Ardagna, Silvia, Francesco Caselli, and Timothy Lane. 2004. "Fiscal Discipline and the Cost of Public Debt Service: Some Estimates for OECD Countries." Working Paper 10788. Cambridge, Mass.: National Bureau of Economic Research (September).

Aschauer, David A. 1985. "Fiscal Policy and Aggregate Demand." American Economic Review 75: 117-27.

Auerbach, Alan J. 1994. "The U.S. Fiscal Problem: Where We Are, How We Got Here, and Where We're Going." In NBER Macroeconomics Annual, edited by Stanley Fischer and Julio Rotemberg. Cambridge, Mass.: National Bureau of Economic Research.

Auerbach, Alan J., and Laurence Kotlikoff. 1987. Dynamic Fiscal Policy. Cambridge, U.K.: Cambridge University Press.

Auerbach, Alan J., William G. Gale, and Peter R. Orszag. 2004. "Sources of the Fiscal Gap." Tax Notes 103, no. 8: 1049-59.

Auerbach, Alan J., and others. 2003. "Budget Blues: The Fiscal Outlook and Options for Reform." In Agenda for the Nation, edited by Henry Aaron, James Lindsey, and Pietro Nivola. Brookings.

Ball, Laurence, and N. Gregory Mankiw. 1995. "What Do Budget Deficits Do?" In Budget Deficits and Debt: Issues and Options. Kansas City, Mo.: Federal Reserve Bank of Kansas City.

Barro, Robert J. 1974. “Are Government Bonds Net Worth?” Journal of Political Economy 82, no. 6: 1095-1117.

. 1979. "On the Determination of the Public Debt." Journal of Political Economy, 87, no. 5: 940-71.

1989. "The Ricardian Approach to Budget Deficits." Journal of Economic Perspectives 3, no. 2: 37-54.

1991. “World Interest Rates and Investment.” Working Paper 3849. Cambridge, Mass.: National Bureau of Economic Research (September).

Barro, Robert J., and Xavier Sala-i-Martin. 1991. "World Real Interest Rates." Working Paper 3317. Cambridge, Mass.: National Bureau of Economic Research (April).

Barsky, Robert B., N. Gregory Mankiw, and Stephen P. Zeldes. 1986. "Ricardian Consumers with Keynesian Propensities." American Economic Review 76, no. 4: 676-91.

Barth, James R., and Michael D. Bradley. 1989. "Evidence on Real Interest Rate Effects of Money, Debt, and Government Spending." Quarterly Review of Economics and Business 29, no. 1: 49-57. 
Barth, James R., George Iden, and Frank S. Russek. 1985. "Federal Borrowing and Short Term Interest Rates: Comment." Southern Economic Journal 52, no. 2: 554-59.

1986. "Government Debt, Government Spending, and Private Sector Behavior: Comment." American Economic Review 76, no. 5: 1158-67.

Barth, James R., and others. 1991. "The Effects of Federal Budget Deficits on Interest Rates and the Composition of Domestic Output." In The Great Fiscal Experiment, edited by Rudolph G. Penner. Washington: Urban Institute Press.

Bernheim, B. Douglas. 1987. "Ricardian Equivalence: An Evaluation of Theory and Evidence." In NBER Macroeconomics Annual, Vol. 2, edited by Stanley Fischer. Cambridge, Mass.: National Bureau of Economic Research and MIT Press.

1989. "A Neoclassical Perspective on Budget Deficits." Journal of Economic Perspectives 3, no. 2: 55-72.

Blanchard, Olivier J. 1985. "Debt, Deficits, and Finite Horizons." Journal of Political Economy 93, no. 2: : 223-47.

Blanchard, Olivier J., and Stanley Fischer. 1989. Lectures on Macroeconomics. MIT Press.

Bovenberg, A. Lans. 1988. "Long-Term Interest Rates in the United States." International Monetary Fund Staff Papers 35, no. 2: 382-90.

Bradley, Michael D. 1986. "Government Spending or Deficit Financing: Which Causes Crowding Out?" Journal of Economics and Business 38, no. 3: 203-14.

Brook, Anne-Marie. 2003. "Recent and Prospective Trends in Real Long-Term Interest Rates: Fiscal Policy and Other Drivers." OECD Economics Department Working Paper 367. Paris: OECD (September 29).

Burman, Leonard E., William G. Gale, and Jeffrey Rohaly. 2003. "The Expanding Role of the Alternative Minimum Tax." Journal of Economic Perspectives 17, no. 2: $173-86$.

Calomiris, Charles W., and others. 2004. "Do Budget Deficit Announcements Move Interest Rates?” Washington: American Enterprise Institute (December).

Campbell, John Y., and N. Gregory Mankiw. 1989. "Consumption, Income, and Interest Rates: Reinterpreting the Time Series Evidence." In NBER Macroeconomics Annual, edited by Olivier Blanchard and Stanley Fischer. MIT Press.

1990. "Permanent Income, Current Income and Consumption." Journal of Business and Economic Statistics 8, no. 3: 265-79.

Canto, Victor A., and Donald Rapp. 1982. "The 'Crowding Out' Controversy: Arguments and Evidence." Federal Reserve Bank of Atlanta Economic Review (August): $33-37$.

Canzoneri, Matthew B., Robert E. Cumby, and Behzad T. Diba. 2002. "Should the European Central Bank and the Federal Reserve Be Concerned about Fiscal Policy?" Presented at the Federal Reserve Bank of Kansas City's symposium on "Rethinking Stabilization Policy," Jackson Hole, Wyo., August. 
Cardia, Emanuela. 1997. "Replicating Ricardian Equivalence Tests with Simulated Series." American Economic Review 87, no. 1: 65-79.

Carlson, Jack. 1983. "The Relationship between Federal Deficits and Interest Rates." Statement before the Joint Economic Committee (October 21).

Carroll, Chris, and Lawrence H. Summers. 1987. "Why Have Private Savings Rates in the United States and Canada Diverged?" Journal of Monetary Economics 20: 249-79.

Cebula, Richard J. 1987. The Deficit Problem in Perspective. Lexington, Mass.: D. C. Heath. . 1988. "Federal Government Budget Deficits and Interest Rates: A Brief Note.” Southern Economic Journal 55, no.1: 206-10.

2000. "Impact of Budget Deficits on Ex Post Real Long-Term Interest Rates." Applied Economics Letters 7: 177-79.

Cebula, Richard J., and James V. Koch. 1989. "An Empirical Note on Deficits, Interest Rates, and International Capital Flows." Quarterly Review of Economics and Business 29, no. 3: 121-27.

1994. "Federal Budget Deficits, Interest Rates, and International Capital Flows: A Further Note." Quarterly Review of Economics and Finance 34, no. 1: 117-20.

Cohen, Darrel, and Glenn Follette. 2003. "Forecasting Exogenous Fiscal Variables in the United States." Finance and Economics Discussion Series. Washington: Board of Governors of the Federal Reserve System (November 5).

Cohen, Darrel, and Olivier Garnier. 1991. "The Impact of Forecasts of Budget Deficits on Interest Rates in the United States and Other G-7 Countries." Washington: Division of Research and Statistics, Federal Reserve Board.

Coorey, Sharmini. 1992. "The Determinants of U.S. Real Interest Rates in the Long Run." In The United States Economy: Performance and Issues, edited by a staff team headed by Yusuke Horiguchi. Washington: International Monetary Fund.

Cox, W. Michael. 1985. "The Behavior of Treasury Securities Monthly, 19421984.” Journal of Monetary Economics 16: 227-40.

Dai, Qiang, and Thomas Philippon. 2004. "Government Deficits and Interest Rates: A No-Arbitrage Structural VAR Approach.” New York University (March 14).

De Leeuw, Frank, and Thomas M. Holloway. 1985. "The Measurement and Significance of the Cyclically Adjusted Federal Budget and Debt." Journal of Money, Credit, and Banking 17, no. 2: 232-42.

Dennis, Robert, and others. 2004. "Macroeconomic Analysis of a 10 Percent Cut in Income Tax Rates." Washington: Congressional Budget Office (May).

De Serres, Alain, and Florian Pelgrin. 2003. "The Decline in Private Saving Rates in the 1990s in OECD Countries: How Much Can Be Explained by Non-Wealth 
Determinants?" OECD Economics Department Working Paper 344. Paris: OECD.

Dewald, William G. 1983. "Federal Deficits and Interest Rates: Theory and Evidence.” Federal Reserve Bank of Atlanta Economic Review (January): 20-29.

Dornbusch, Rudiger. 1991. "National Saving and International Investment: Comment." In National Saving and Economic Performance, edited by B. Douglas Bernheim and John B. Shoven. University of Chicago Press.

Echols, Michael E., and Jan Walter Elliott. 1976. "Rational Expectations in a Disequilibrium Model of the Term Structure." American Economic Review 66, no.1: $28-44$.

Elmendorf, Douglas W. 1993. “Actual Budget Deficits and Interest Rates.” Department of Economics, Harvard University (March).

1996. "The Effects of Deficit Reduction Laws on Real Interest Rates." Finance and Economics Discussion Series 1996-44. Washington: Board of Governors of the Federal Reserve (October).

Elmendorf, Douglas W., and Jeffrey B. Liebman. 2000. "Social Security Reform and National Saving in an Era of Budget Surpluses." BPEA, no. 2: 1-71.

Elmendorf, Douglas W., and N. Gregory Mankiw. 1999. "Government Debt.” In Handbook of Macroeconomics, Vol. 1C, edited by John B. Taylor and Michael Woodford. Amsterdam: Elsevier Science.

Engen, Eric M., and R. Glenn Hubbard. Forthcoming. "Federal Government Debt and Interest Rates." In NBER Macroeconomics Annual, edited by Mark Gertler and Kenneth Rogoff. MIT Press.

Evans, Paul. 1985. "Do Large Deficits Produce High Interest Rates?" American Economic Review 75, no. 1: 68-87.

1987a. "Interest Rates and Expected Future Budget Deficits in the United States.” Journal of Political Economy 95, no. 11: 34-58.

. 1987b. "Do Budget Deficits Raise Nominal Interest Rates? Evidence from Six Countries.” Journal of Monetary Economics 20: 281-300.

. 1988. “Are Consumers Ricardian?” Journal of Political Economy 96, no. 5: 983-1004.

. 1989. "A Test of Steady-State Government-Debt Neutrality." Economic Inquiry 27 (January): 39-55.

. 1991. "Is Ricardian Equivalence a Good Approximation?" Economic Inquiry 29, no. 4: 626-44.

. 1993. "Consumers Are Not Ricardian: Evidence from Nineteen Countries." Economic Inquiry 31(October): 534-48.

Evans, Paul, and Iftekhar Hasan. 1994. "Are Consumers Ricardian? Evidence for Canada.” Quarterly Review of Economics and Finance 34, no. 1: 25-40. 
Feldstein, Martin S. 1982. "Government Deficits and Aggregate Demand." Journal of Monetary Economics 9: 1-20.

1986. "Budget Deficits, Tax Rules, and Real Interest Rates. ” Working Paper 1970. Cambridge, Mass.: National Bureau of Economic Research (July).

1988. "The Effects of Fiscal Policies When Incomes Are Uncertain: A Contradiction to Ricardian Equivalence." American Economic Review 78, no. 1: $14-23$.

Feldstein, Martin S., and Gary Chamberlain. 1973. "Multimarket Expectations and the Rate of Interest." Journal of Money, Credit, and Banking 4, no. 4: 873-902.

Feldstein, Martin S., and Otto Eckstein. 1970. "The Fundamental Determinants of the Interest Rate." Review of Economics and Statistics 52, no. 4: 363-75.

Feldstein, Martin, and Douglas W. Elmendorf. 1990. "Government Debt, Government Spending, and Private Sector Behavior Revisited: Comment." American Economic Review 80, no. 3: 589-99.

Feldstein, Martin S., and Charles Horioka. 1980. "Domestic Savings and International Capital Flows.” Economic Journal 90, no. 358: 314-29.

Flavin, Marjorie. 1987. “Comment.” In NBER Macroeconomics Annual, edited by Stanley Fischer. Cambridge, Mass.: National Bureau of Economic Research and MIT Press.

Frankel, Jeffrey A. 1983. "A Test of Portfolio Crowding-Out and Related Issues of Finance.” Working Paper 1205. Cambridge, Mass.: National Bureau of Economic Research (September).

Friedman, Benjamin. 1988. Day of Reckoning: The Consequences of American Economic Policy Under Reagan and After. Random House.

Gale, William G., and Peter R. Orszag. 2002. “The Economic Effects of Long-Term Fiscal Discipline.” Discussion Paper. Washington: Urban-Brookings Tax Policy Center (December 17).

. 2003a. "Economic Effects of Sustained Budget Deficits." National Tax Journal 56: 463-85 (September).

2003b. "Sunsets in the Tax Code." Tax Notes 99, no. 10: 1553-61.

2003c. "Effects of Fiscal Policy on Aggregate Consumption and Saving: A Re-evaluation of Ricardian Equivalence." Brookings (December; also presented at the American Economic Association Meeting, San Diego, January 2004).

. 2004a. "Economic Effects of Making the 2001 and 2003 Tax Cuts Permanent." International Tax and Public Finance. Forthcoming.

.2004b. "Tax Cuts, Interest Rates, and the User Cost of Capital." Brookings.

Gale, William G., and Samara R. Potter. 2002. "An Economic Evaluation of the Economic Growth and Tax Relief Reconciliation Act of 2001." National Tax Journal 55, no. 1: 133-86. 
Giannaros, Demetrios S., and Bharat R. Kolluri. 1985. "Deficit Spending, Money, and Inflation: Some International Empirical Evidence." Journal of Macroeconomics 7, no. 3: 401-17.

Gokhale, Jagadeesh, and Kent Smetters. 2003. Fiscal and Generational Imbalances: New Budget Measures for New Budget Priorities. Washington: AEI Press.

Graham, Fred C. 1992. "On the Importance of the Measurement of Consumption in Tests of Ricardian Equivalence.” Economic Letters 38, no. 4: 431-34.

. 1995. "Government Debt, Government Spending, and Private-Sector Behavior: Comment.” American Economic Review 85, no. 5: 1348-56.

Graham, Fred C., and Daniel Himarios. 1991. "Fiscal Policy and Private Consumption: Instrumental Variables Tests of the 'Consolidated Approach." Journal of Money, Credit and Banking 23, no. 1: 53-67.

1996. "Consumption, Wealth, and Finite Horizons: Tests of Ricardian Equivalence.” Economic Inquiry 34: 527-44.

Gravelle, Jane G. 1994. The Economic Effects of Taxing Capital Income. MIT Press.

2004. "Historical Effective Marginal Tax Rates on Capital Income." Congressional Research Service Report for Congress. Washington: Congressional Research Service (January 12).

Hall, Robert E. 1978. "Stochastic Implications of the Life Cycle-Permanent Income Hypothesis." Journal of Political Economy 86: 971-87.

1988. "Intertemporal Substitution in Consumption." Journal of Political Economy 96: 339-57.

Hayashi, Fumio. 1982. "The Permanent Income Hypothesis: Estimation and Testing by Instrumental Variables.” Journal of Political Economy 90: 895-916.

Hoelscher, Gregory P. 1983. "Federal Borrowing and Short Term Interest Rates." Southern Economic Journal 50 (October): 319-33.

1986. "New Evidence on Deficits and Interest Rates." Journal of Money, Credit, and Banking 18, no. 1: 1-17.

Hubbard, R. Glenn, and Kenneth L. Judd. 1986. "Liquidity Constraints, Fiscal Policy, and Consumption.” BPEA, no. 1: 1-59.

Hutchison, Michael, and David H. Pyle. 1984. "The Real Interest Rate/Budget Deficit Link: International Evidence, 1973-1982." Federal Reserve Bank of San Francisco Economic Review (Fall): 26-35.

Johnson, David S., Jonathan A. Parker, and Nicholas S. Souleles. 2004. "The Response of Consumer Spending to the Randomized Income Tax Rebates of 2001." Bureau of Labor Statistics, Princeton University, and University of Pennsylvania (February).

Joint Committee on Taxation. 2001. "Estimated Budget Effects of the Conference Agreement for H.R.: 1836[1].” Document JCX-51-01. Washington (May 26). 
2002. "Estimated Revenue Effects of the 'Job Creation and Worker Assistance Act of 2002.'” Document JCX-13-02. Washington (March 6).

2003. "Estimated Budget Effects of the Conference Agreement for H.R. 2.: The Jobs and Growth Tax Relief Reconciliation Act of 2003." Document JCX55-03. Washington (May 22).

Judd, Kenneth L. 1985. "Short Run Analysis of Fiscal Policy in a Simple Perfect Foresight Model.” Journal of Political Economy 93, no. 2: 298-319.

. 1987a. "The Welfare Cost of Factor Taxation in a Perfect Foresight Model." Journal of Political Economy 95, no. 4: 675-709.

.1987b. "Debt and Distortionary Taxation in a Simple Perfect Foresight Model." Journal of Monetary Economics 20, no. 5: 1-72.

Kiley, Michael T. 2003. "The Effect of Government Debt on the Return to Capital." Washington: Board of Governors of the Federal Reserve (December).

Kim, Sun-Young, and Raymond E. Lombra. 1989. "Why the Empirical Relationship between Deficits and Interest Rates Appears So Fragile." Journal of Economics and Business 41, no. 3: 241-51.

Kitchen, John. 1996. "Domestic and International Financial Market Responses to Federal Deficit Announcements." Journal of International Money and Finance 15, no. 2: 239-54.

2002. "A Note on Interest Rates and Structural Federal Budget Deficits." Washington: House Budget Committee (October).

Kolluri, Bharat R., and Demetrios S. Giannaros. 1987. "Budget Deficits and Shortterm Real Interest Rate Forecasting." Journal of Macroeconomics 9, no. 1: $109-25$.

Kormendi, Roger. 1983. "Government Debt, Government Spending, and Private Sector Behavior." American Economic Review 73, no. 5: 994-1010.

Kormendi, Roger C., and Philip Meguire. 1986. "Government Debt, Government Spending, and Private Sector Behavior: Reply." American Economic Review 76, no. 5: 1180-87.

1990. "Government Debt, Government Spending, and Private Sector Behavior: Reply and Update.” American Economic Review 80, no. 3: 604-17.

. 1995. "Government Debt, Government Spending, and Private Sector Behavior: Reply.” American Economic Review 85, no. 5: 1357-61.

Kormendi, Roger C., and Aris Protopapadakis. 2004. "Budget Deficits, Current Account Deficits, and Interest Rates: The Systematic Evidence on Ricardian Equivalence." Center for Society and Economy, Business School, University of Michigan.

Kudlow, Lawrence. 1981. "Statement before the Senate Budget Committee: Statistical Appendix" (October 20). 
Laubach, Thomas. 2003. "New Evidence on the Interest Rate Effects of Budget Deficits and Debt." Washington: Board of Governors of the Federal Reserve System (May).

Lee, Ronald, and Ryan Edwards. 2001. "The Fiscal Impact of Population Change." In Seismic Shifts: The Economic Impact of Demographic Change, edited by Jane Sneddon Little and Robert K. Triest. Conference Series 46. Federal Reserve Bank of Boston.

Makin, John H. 1983. "Real Interest, Money Surprises, Anticipated Inflation and Fiscal Deficits." Review of Economics and Statistics 65, no. 3: 374-84.

Makin, John H., and Vito Tanzi. 1984. "Level and Volatility of U.S. Interest Rates: Roles of Expected Inflation, Real Rates and Taxes." In Taxation, Inflation, and Interest Rates, edited by Vito Tanzi. Washington: International Monetary Fund.

Mankiw, N. Gregory. 1990. “A Quick Refresher Course in Macroeconomics.” Journal of Economic Literature 28, no. 4: 1645-60.

1992. "The Reincarnation of Keynesian Economics." European Economic Review 36: 559-65.

2000a. Macroeconomics. New York: Worth Publishers.

2000b. "The Savers-Spenders Theory of Fiscal Policy." American Economic Review 90 (Papers and Proceedings), no. 2: 120-25.

Mascaro, Angelo, and Allen H. Meltzer. 1983. "Long- and Short-Term Interest Rates in a Risky World." Journal of Monetary Economics 12, no. 4: 485-518.

Meguire, Philip. 1998. "Comment: Social Security and Private Savings.” National Tax Journal 51, no. 2: 339-58.

2003. "Social Security and Personal Saving: 1971 and Beyond." Empirical Economics 28, no. 1: 115-39.

Miller, Stephen M., and Frank S. Russek. 1991. "The Temporal Causality between Fiscal Deficits and Interest Rates," Contemporary Policy Issues 9: 12-23.

1996. "Do Federal Deficits Affect Interest Rates? Evidence from Three Econometric Methods.” Journal of Macroeconomics 18, no. 3: 403-28.

Modigliani, Franco, and Arlie G. Sterling. 1986. "Government Debt, Government Spending, and Private Sector Behavior: Comment." American Economic Review 76, no. 5: 1168-79.

Motley, Brian. 1983. "Real Interest Rates, Money and Government Deficits." Federal Reserve Bank of San Francisco Economic Review (Summer): 31-45.

Mountford, Andrew, and Harald Uhlig. 2000. "What Are the Effects of Fiscal Policy Shocks?" London: Centre for Economic Policy Research (October).

Muller, Patrice, and Robert Price. 1984. "Public Sector Indebtedness and LongTerm Interest Rates." Paper presented at the World Bank/Brookings Institution Workshop on "International Consequences of Budgetary Deficits in the OECD," Washington, September. 
Perotti, Roberto. 2002. "Estimating the Effects of Fiscal Policy in OECD Countries." Presented at the International Seminar on Macroeconomics (ISOM), Frankfurt, June.

Plosser, Charles I. 1982. "Government Financing Decisions and Asset Returns." Journal of Monetary Economics 9, no. 3: 325-52.

1987a. "Fiscal Policy and the Term Structure." Journal of Monetary Economics 20, no. 6: 343-67.

1987b. "Comment." In NBER Macroeconomics Annual, edited by Stanley Fischer. Cambridge, Mass.: National Bureau of Economic Research and MIT Press.

Poterba, James M., and Lawrence H. Summers. 1986. "Finite Lifetimes and the Crowding Out Effects of Budget Deficits." Working Paper 1955. Cambridge, Mass.: National Bureau of Economic Research (June).

. 1987. "Recent US Evidence on Budget Deficits and National Savings." Working Paper 2144. Cambridge, Mass.: National Bureau of Economic Research (February).

Quigley, Michael Regan, and Susan Porter-Hudak. 1994. "A New Approach in Analyzing the Effect of Deficit Announcements on Interest Rates." Journal of Money, Credit, and Banking 26, no. 4: 894-902.

Ramey, Valerie A., and Matthew D. Shapiro. 1998. "Costly Capital Reallocation and the Effects of Government Spending." Carnegie Rochester Conference Series on Public Policy 48 (June): 145-94.

Romer, David. 1996. Advanced Macroeconomics. McGraw Hill.

Rubin, Robert E., Peter R. Orszag, and Allen Sinai. 2004. "Sustained Budget Deficits: Longer-Run U.S. Economic Performance and the Risk of Financial and Fiscal Disarray." Paper presented at the AEA-NAEFA Joint Session, Allied Social Science Associations Annual Meetings, The Andrew Brimmer Policy Forum, "National Economic and Financial Policies for Growth and Stability," San Diego, January 4.

Seater, John J. 1981. "The Market Value of Outstanding Government Debt, 19191975." Journal of Monetary Economics 8 (July): 85-101. 142-90.

1993. "Ricardian Equivalence." Journal of Economic Literature 31, no. 1:

Seater, John J., and Roberto S. Mariano. 1985. "New Tests of the Life-Cycle and Tax-Discounting Hypotheses." Journal of Monetary Economics (March): 195-215.

Shapiro, Matthew. Forthcoming. "Comment." In NBER Macroeconomics Annual, edited by Mark Gertler and Kenneth Rogoff. MIT Press.

Shapiro, Matthew D., and Joel Slemrod. 2003. "Did the 2001 Tax Rebate Stimulate Spending? Evidence from Taxpayer Surveys." In Tax Policy and the Economy, Vol. 17, edited by James Poterba. MIT Press. 
Shoven, John B. 2002. "The Impact of Major Life Expectancy Improvements on the Financing of Social Security, Medicare and Medicaid." In Creating Methuselah: Molecular Medicine and the Problems of an Aging Society, edited by Henry J. Aaron and William B. Schwartz. Brookings.

Sinai, Allen, and Peter Rathjens. 1983. "Deficits, Interest Rates, and the Economy." Data Resources U.S. Review (June): 1.27-1.41.

Smetters, Kent. 1999. "Ricardian Equivalence: Long-Run Leviathan." Journal of Public Economics 73, no. 3: 395-421.

Summers, Lawrence H. 1985. "Issues in National Savings Policy.” Working Paper 1710. Cambridge, Mass.: National Bureau of Economic Research.

Swamy, P. A. V. B., Bharat R. Kolluri, and Rao N. Singamsetti. 1988. "What Do Regressions of Interest Rates on Deficits Imply?" Finance and Economics Discussion Series 3. Washington: Division of Research and Statistics, Board of Governors of the Federal Reserve (January).

Tanzi, Vito. 1985. "Fiscal Deficits and Interest Rates in the United States, An Empirical Analysis, 1960-1984.” International Monetary Fund Staff Papers 32, no. 4: 551-76.

Tatom, John A. 1984. "A Perspective on the Federal Deficit Problem." Federal Reserve Bank of St. Louis Review 66, no. 6: 5-17.

Tavares, Jose, and Rossen Valkanov. 2001. "The Neglected Effect of Fiscal Policy on Stock and Bond Returns." Anderson School, University of California, Los Angeles (October).

Thomas, Lloyd B., Jr., and Ali Abderrezak. 1988a. "Anticipated Future Budget Deficits and the Term Structure of Interest Rates." Southern Economic Journal 55, no. 1: 150-61.

1988b. "Long-Term Interest Rates: The Role of Expected Budget Deficits." Public Finance Quarterly 16, no. 3: 341-56.

Thorbecke, Willem. 1993. "Why Deficit News Affects Interest Rates." Journal of Policy Modeling 15, no. 1: 1-11.

Truman, Edwin M. 2001. "The International Implications of Paying Down the Debt." Policy Brief Number 01v7. Washington: Institute for International Economics.

United States Department of the Treasury. 1984. The Effects of Deficits on Prices of Financial Assets: Theory and Evidence. Washington (March).

Wachtel, Paul, and John Young. 1987. "Deficit Announcements and Interest Rates." American Economic Review 77, no. 5: 1007-12.

Zahid, Khan H. 1988. "Government Budget Deficits and Interest Rates: The Evidence Since 1971, Using Alternative Deficit Measures.” Southern Economic Journal 54, no. 3: 725-31. 